\title{
BIOLOGICAL PRODUCTION OF ACETALDEHYDE \\ FROM ETHANOL USING NON-GROWING \\ PICHIA PASTORIS WHOLE CELLS
}

\author{
By \\ HEIEN-KUN CHIANG \\ Bachelor of Science \\ Tunghai University \\ Taichung, Taiwan
}

1984
Submitted to the Faculty of the Graduate College of the Oklahoma state University in partial fulfillment of the requirements for the Degree of MASTER OF SCIENCE May, 1989




\section{Thesis 1989 \\ c $532 b$ cop. 2}




\section{Oklahoma State Univ. Library}

BIOLOGICAL PRODUCTION OF ACETALDEHYDE

FROM ETHANOL USING NON-GROWING

PICHIA PASTORIS WHOLE CELLS

Thesis Approved:

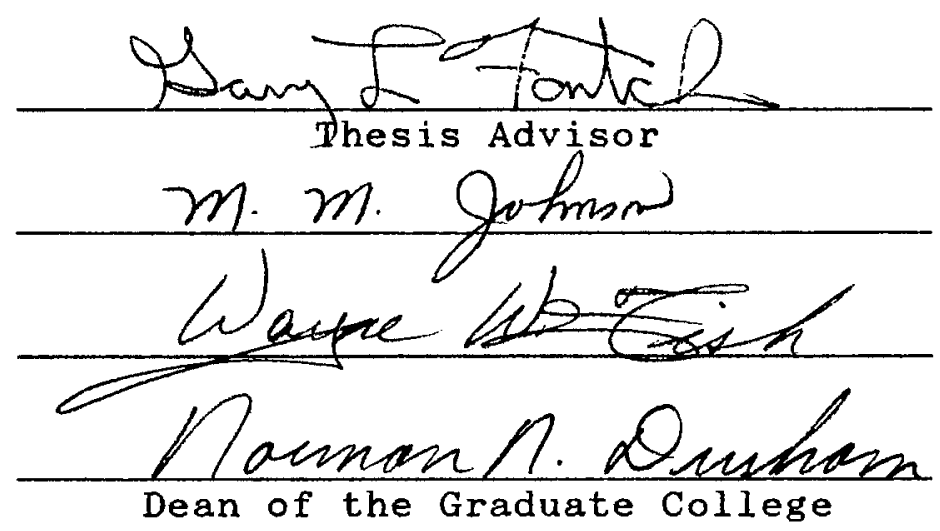




\section{ACKNOWLEDGMENTS}

I wish to express my deepest thanks and appreciation to my thesis adviser, Dr. Gary L. Foutch, for his guidance and valuable suggestions throughout the study. It is his research during the summer of 1987 in Phillips Petroleum Company and the proposal written by him that made this study possible.

I would also like to express my appreciation to Dr. Wayne W. Fish and Dr. Marvin M. Johnson as members of my examining committee.

I am grateful to Oklahoma State University School of Chemical Engineering which has provided space, facilities and materials throughout this research.

I shall always be thankful to Phillips Petroleum Company for equipment, advice and financial support provided for the completion of this project. Particular thanks is to Dr. Wayne W. Fish and members of their biotechnology group for their help.

Finally, I am deeply indebted to my parents, Mr. and Mrs. Han-Weng Chiang, my English tutor and his wife (they are also my adopted parents), Mr. and Mrs. Alton Juhlin, and my wife, Feng-Lan Kuo, for their understanding, assistance and encouragement. 
TABLE OF CONTENTS

Chapter page

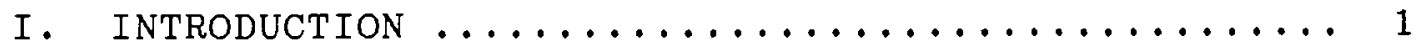

II. LiteratuRE REVIEW ................... 3

Physical and Chemical Properties of

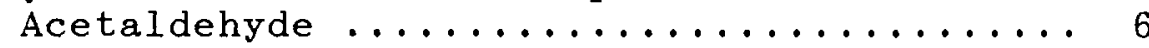

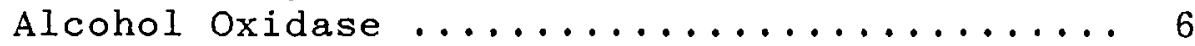

The Enzyme Reaction Mechanism ........... 12

Operating Variables Inside the Bioreactor ... 12

III. EXPERIMENTAL APPARATUS, PROCEDURES AND

ANALYTICAL METHODS .................. 19

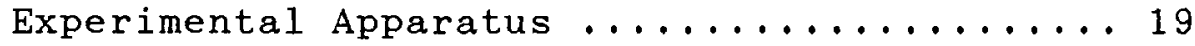

Description of System Process ........... 24

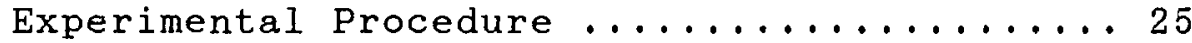

Calibration Procedure ............ 25

Operating Procedure ............. 26

Materials and Methods ................ 27

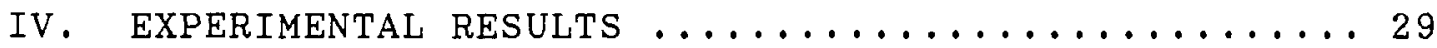

First Stage: Preliminary Study ......... 29

Second Stage: Variable Investigation ...... 35

V. MATHEMATICAL MODEL DEVELOPMENT ............. 43

Description of Modeled System ...........43

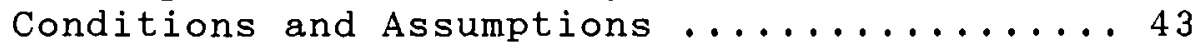

Mathematical Expression ..............446

VI. REACTOR DESIGN AND ECONOMIC EVALUATION

OF AN ACETALDEHYDE BIOPROCESS ............660

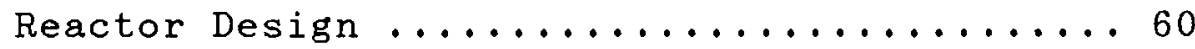

Conditions and Assumptions ............. 60

Economic Evaluation of Acetaldehyde

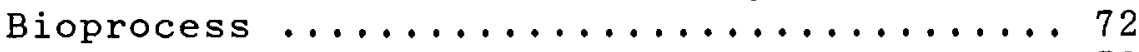

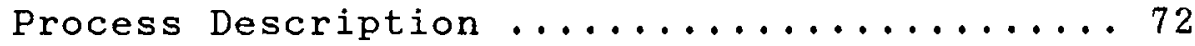

Estimation of Cost ................ 74 


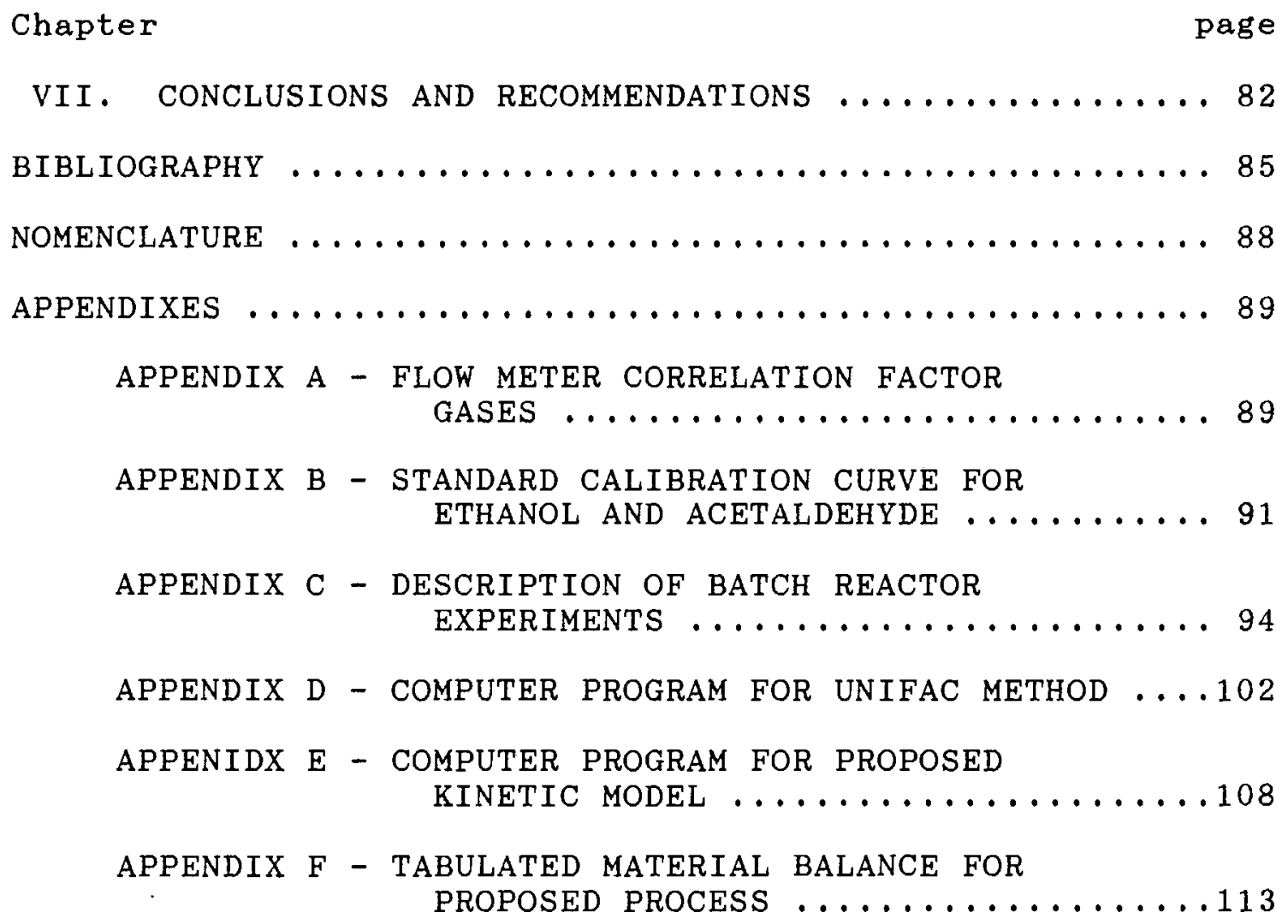




\section{LIST OF TABLES}

Table

page

1. Foods containing acetaldehyde ............... 4

2. Some physical properties of acetaldehyde ....... 7

3 A. Vapor pressure of acetaldehyde $\ldots \ldots \ldots \ldots \ldots \ldots$

3B. Vapor pressure of aqueous solutions of acetaldehyde ....................... 8

4. Properties of alcohol oxidase from various

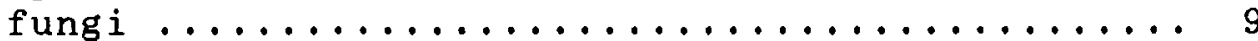

5. The optimal temperature and $\mathrm{pH}$ for some methanol-grown cells ................. 14

6. Apparent $\mathrm{Km}$ values of various hydrogen peroxide-producing oxidases ............. 16

7. Summary of experimental operating conditions .... 30

8. The daily acetaldehyde production of all three batches operated in sequence ............66

9. Estimation of capital cost (case 1: 75,000 gal/yr acetaldehyde production) ..........776

10. Estimation of capital cost (case 2: 125,000 gal/yr acetaldehyde production) .......... 77

11. Estimation of capital cost (case 3: 200,000 gal/yr acetaldehyde production) ........... 78

12. Estimation of production cost (case 1: 75,000 gal/yr acetaldehyde production) ........... 79

13. Estimation of production cost (case 2: 125,000 gal/yr acetaldehyde production) .......... 80

14. Estimation of production cost (case 3:200,000 gal/yr acetaldehyde production) ...........8 81

15. Specific gravity correlation factor for gases ....99 
16. Standard calibration data for acetladehyde

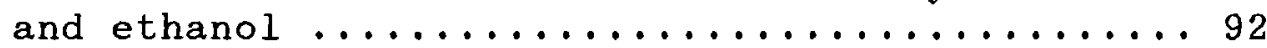

17. Material balance (case 1:75,000 gal/yr acetaldehyde production) ..................114

18. Material balance (case 2: 125,000 gal/yr acetaldehyde production) ...............115

19. Material balance (case 3: 200,000 gal/yr acetaldehyde production) .............116 


\section{LIST OF FIGURES}

Figure

page

1. Acetaldehyde from ethylene by single-stage oxidation with oxygen ................. 5

2. Pathway for the oxidation of methanol by

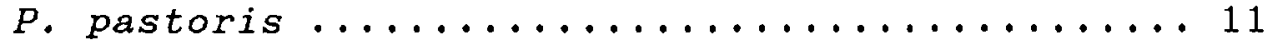

3. The effect of end product inhibition by acetaldehyde on alcohol oxidase .......... 18

4. Bioreactor instrumentation for converting ethanol to acetaldehyde (first-stage) ........20

5. Schematic diagram of acetaldehyde bioreactor system (second-stage) ................. 21

6. Effect of substrate (ethanol) concentration on initial production rate of acetaldehyde ....3 31

7. Acetaldehyde concentration profile in fermentor under different substrate concentrations ..... 32

8. Acetaldehyde concentration profile in fermentor for Expts 2,4 , and $5 \ldots \ldots \ldots \ldots \ldots \ldots$

9. Acetaldehyde concentration profile in fermentor under controlled gas flow rate .......... 36

10. A comparison of acetaldehyde production between Expt 3 and Expt $3 a \ldots \ldots \ldots \ldots \ldots \ldots \ldots \ldots$

11. Acetaldehyde concentration profile in fermentor for $\operatorname{Expts} 7,8$, and $9 \ldots \ldots \ldots \ldots \ldots \ldots \ldots$

12. Acetaldehyde concentration profile in fermentor with differnt ratios of air to oxygen .......44 4

13. Acetaldehyde concentration profile in fermentor under different substrate concentrations ......442

14. The system configuration for acetaldehyde bioreactor ....................... 44 
15. The feed pattern of ethanol and possible acetaldehyde profile .................445

16. The acetaldehyde concentration in an no reaction stripping system ............. 53

17. The ethanol concentration in an no reaction stripping system ................... 54

18. A fit to Expt $14(10 \%$ ethanol) by proposed model ........................ 57

19. A fit to Expt 15 ( $5 \%$ ethanol) by proposed model .......................... 58

20. A fit to Expt $16(15 \%$ ethnaol) by proposed

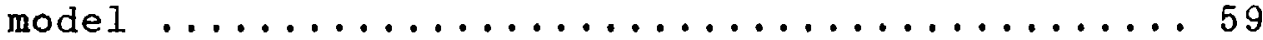

21. The graphic method for total acetaldehyde produced in one batch (case 1$) \ldots \ldots \ldots 62$

22. The graphic method for total acetaldehyde produced in one batch (case 2) ...........665

23. The daily acetaldehyde production rate for all three batches ooperated in sequence ......667

24. The enzyme activity vs. time for three different cell withdrawn/fed strategies ......669

25. The acetaldehyde conc. profile vs. time for three different cell withdrawn/fed

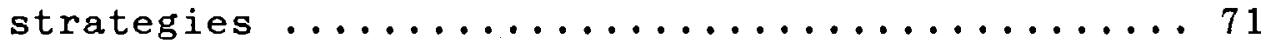

26. The proposed process for acetaldehyde

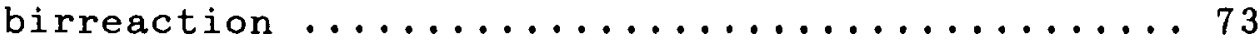

27. Standard calibration curves for acetaldehyde and ethanol ........................ 93 
CHAPTER I

\section{INTRODUCTION}

Acetaldehyde (ethanal, IUPAC) is recognized as an important feedstock in chemical industries. It is an intermediate in the manufacturing of acetic acid, acid anhydride, butyl alcohol, butyraldehyde, chloral, pyridines, and other derivatives. Traditionally, acetaldehyde is produced synthetically either from the catalytic oxidation of ethyl alcohol or ethylene. Recently, considerable interest has focused on the production of acetaldehyde by biological methods as a natural additive for various foods.

Consumer preference for natural products has caused increased demand for natural flavors. Currently, there is no commercial production of a "natural" acetaldehyde. However, the enzyme, alcohol oxidase, in the peroxisome of Pichia pastoris yeast could be used to produce a "food grade" acetaldehyde. Acetaldehyde produced biologically would have several competitive advantages, such as easier FDA approval and more attractive consumer marketability. Because of these advantages, a "natural, food grade" acetaldehyde is expected to bring about 10 to 100 times the price of acetaldehyde from conventional processes.

Biotechnological processes for the production of 
organic bulk chemical have achieved increasing success. However, difficult downstreams processing (separation) has inhibited many process developments. For the production of acetaldehyde, a liquid phase bioreactor has distinct applicability and may be more competitive, since (1) the substrate, ethanol, is readily available and inexpensive, (2) the reaction scheme is very clean, only ethanol and air enter, and only acetaldehyde, water, air and unreacted ethanol leave, and (3) the acetaldehyde can be removed easily from the fermentor due to its high volatility.

In this research project, a liquid-phase bioreactor is used to examine both the technical and economic feasibility of producing commercial quantities of acetaldehyde from ethanol with non-growing whole yeast cells, Pichia pastoris. The primary objective is to quantify the reaction parameters required to accurately design a commercial bioreactor. The secondary objective is to demonstrate enzyme stability in extended operation. A preliminary process design and economic evaluation for the best operating conditions will be proposed. 
CHAPTER II

\section{LITERATURE REVIEW}

Acetaldehyde is generated in many metabolic processes and occurs naturally in many fruits and other foods (Table 1) [1]. Those familiar with fruit flavors recognize that the presence of acetaldehyde is essential for delivering the taste of freshness. The content of acetaldehyde in human blood originates from the decomposition of ethanol taken in food [2]. Poisoning with acetaldehyde is a possible consequence of extreme alcohol abuse, after oxidation of ethanol in the liver by alcohol dehydrogenase.

Acetaldehyde in crude form (not refined) was first prepared by Scheele in 1774 , by dehydrogenation of ethyl alcohol, and was recognized as a new compound in 1800 by Foureroy and Vauquelin [3]. The formula was established in 1835 by Liebig, who named it "aldehyde" from the Latin words translated as al (cohol) dehyd(regenated) [3]. During World War I, acetaldehyde was used extensively as an intermediate for acetone from acetic acid. Perhaps the most common method of synthesizing acetaldehyde is the liquid phase oxidation of ethylene with a palladium chloride catalyst [4]. The process is shown in Fig 1. 
TABLE 1

FOODS CONTAINING ACETALDEHYDE [1]

\begin{tabular}{llllll}
\hline Fruits & Dairy & Vegetables & Spices & $\begin{array}{l}\text { Alcoholic } \\
\text { beverages }\end{array}$ & Others \\
\hline Apples & Milk & Carrots & Cumin & Beer & Bread \\
Bananas & Cheese & Celery & Fennel & Plum brandy & Caviar \\
Cherries & Yogurt & Cucumbers & Ginger & Whiskey & Eggs \\
Grapes & & Garlic & Mustard & Apple wine & Fish \\
Peaches & & Mushrooms & Rosemary & Wine & Coffee \\
Pears & & & & Tea \\
Plums & Onions & & & \\
\hline
\end{tabular}




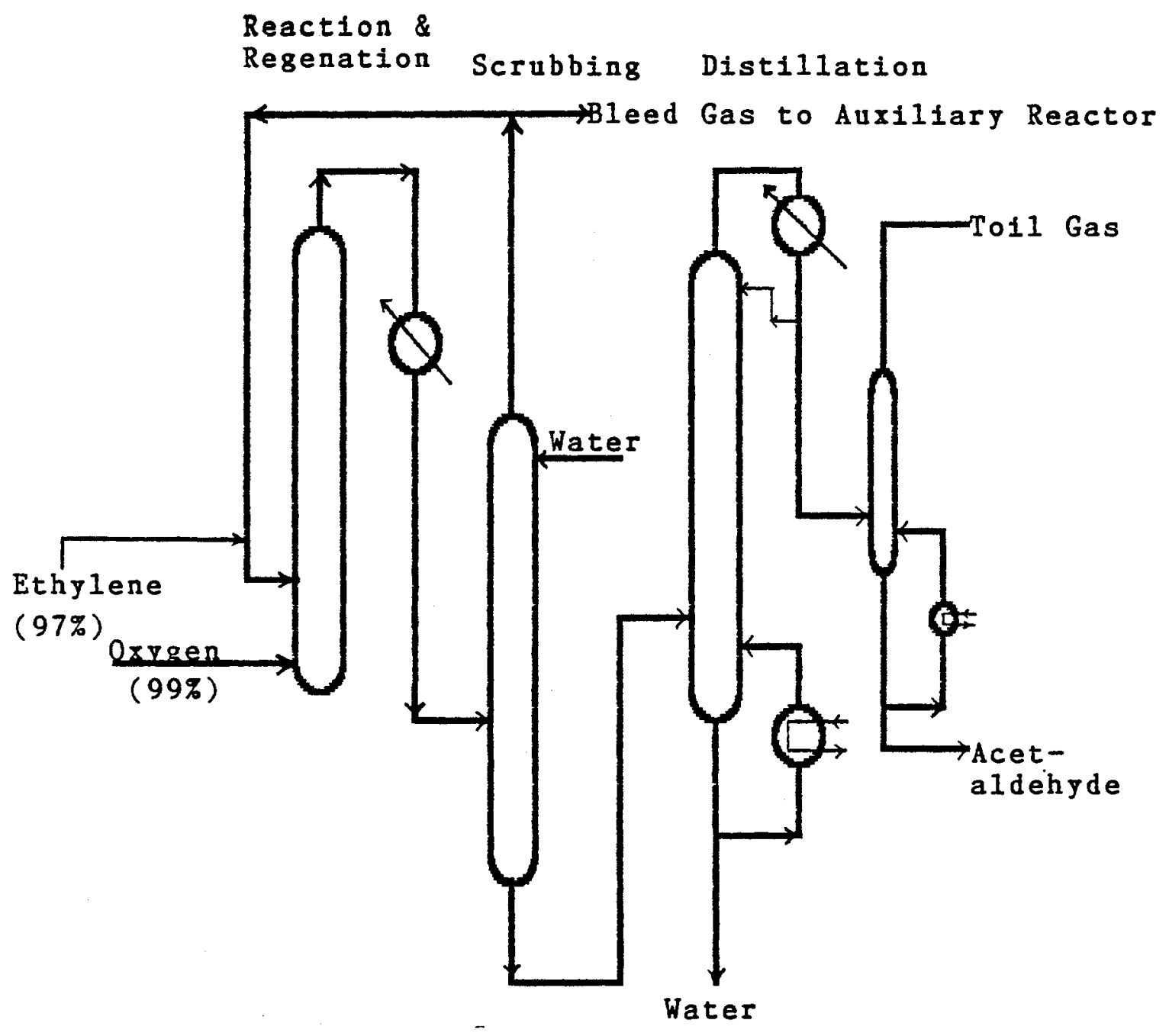

Figure 1. Acetaldehyde from ethylene by single-stage oxidation with oxygen. [3] 


\section{Physical and Chemical Properties}

of Acetaldehyde

The structure of acetaldehyde is :<smiles>CC=O</smiles>

Acetaldehyde is a colorless mobile liquid, boiling at near room temperature, $21^{\circ} \mathrm{C}$. It has a suffocating odor that is somewhat fruity and pleasant in dilute concentration. Mixtures of the vapor with air are highly flammable and explosive. Some physical properties of acetaldehyde are given in Tables 2 and 3 [3]. Acetaldehyde is a highly reactive compound showing the general reactions of aldehydes; undergoing several condensation, addition, and polymerization reactions [5].

\section{Alcohol Oxidase}

Microorganisms capable of growth on one-carbon compounds are abundant in nature, Table 4 [6]. One-carbon compounds are those that possess a single carbon atom and have a degree of oxidation ranging from methane to carbon dioxide. The common characteristic of methanol-grown methyltrophic yeasts is the development of unique subcellular compartments in the cells. These compartments are surrounded by a single membrane and collectively called microbodies, which may have a large variety of enzyme functions. These microbodies contain alcohol oxidase, the 
TABLE 2

SOME PHYSICAL PROPERTIES OF ACETALDEHYDE [3]

\begin{tabular}{|c|c|}
\hline Formula weight & 44.052 \\
\hline Melting point ${ }^{\circ} \mathrm{C}$ & -123.5 \\
\hline Boiling point at $760 \mathrm{~mm},{ }^{\circ} \mathrm{C}$ & 20.16 \\
\hline Density $(g / c c)$ & 0.7780 \\
\hline Coefficient of expansion $/{ }^{\circ} \mathrm{C}\left(0-30^{\circ} \mathrm{C}\right)$ & 0.00169 \\
\hline Refractive index, $\mathrm{nD}$ & 1.33113 \\
\hline Vapor density (air $=1$ ) & 1.52 \\
\hline Surface tension at $20^{\circ} \mathrm{C}$, dyne $/ \mathrm{cm}$ & 21.2 \\
\hline Specific Heat, $\operatorname{cal} /\left({ }^{\circ} \mathrm{C}\right)(\mathrm{g})$, at $0^{\circ} \mathrm{C}$ & 0.522 \\
\hline Specific Heat, $\operatorname{cal} /\left({ }^{\circ} \mathrm{C}\right)(\mathrm{g})$, at $25^{\circ} \mathrm{C}$ & 0.336 \\
\hline$a=\mathrm{Cp} / \mathrm{Cv}$ at $30^{\circ} \mathrm{C}$ and $760 \mathrm{~mm}$ & 1.145 \\
\hline Latent heat of vaporization, cal/g & 139.5 \\
\hline Critical temperature, ${ }^{\circ} \mathrm{C}$ & 181.5 \\
\hline Critical pressure, atm & 63.2 \\
\hline
\end{tabular}


TABLE 3

A. VAPOR PRESSURE OF ACETALDEHYDE [3]

\begin{tabular}{cccc}
\hline $\begin{array}{c}\text { Temperature } \\
\left(\begin{array}{c}\text { C }) \\
-50\end{array}\right.\end{array}$ & $\begin{array}{c}\text { Vapor pressure } \\
(\mathrm{mmHg})\end{array}$ & $\begin{array}{c}\text { Temperature } \\
\left({ }^{\circ}\right)\end{array}$ & $\begin{array}{c}\text { Vapor Pressure } \\
(\mathrm{mmHg})\end{array}$ \\
-20 & 19 & 20 & 755 \\
0 & 123 & 20.16 & 760 \\
5 & 330 & 30 & 1089 \\
10 & 411 & 50 & 2096 \\
15 & 508 & 70 & 3696 \\
\hline
\end{tabular}

B. VAPOR PRESSURE OF AQUEOUS SOLUTIONS

OF ACETALDEHYDE

\begin{tabular}{ccc}
\hline $\begin{array}{c}\text { Temperature } \\
\left({ }^{\circ} \mathrm{C}\right)\end{array}$ & $\begin{array}{c}\text { Mole } \\
(\%)\end{array}$ & $\begin{array}{c}\text { Total vapor pressure } \\
(\mathrm{mmHg})\end{array}$ \\
\hline 10 & 4.9 & 74.9 \\
10 & 10.5 & 139.8 \\
10 & 46.6 & 363.4 \\
20 & 5.4 & 125.2 \\
20 & 12.9 & 295.2 \\
20 & 21.8 & 432.6 \\
\hline
\end{tabular}


TABLE 4

PROPERTIES OF ALCOHOL OXIDASE

FROM VARIOUS FUNGI [6]

\begin{tabular}{|c|c|c|c|c|c|}
\hline \multirow[b]{2}{*}{ Source } & \multicolumn{3}{|c|}{$\mathrm{Km}(\mathrm{mM})$} & \multirow{2}{*}{$\begin{array}{l}\text { Vmax methanol } \\
(\mu \operatorname{mol} \text { min }-1 \\
(\text { mg protein })-1)\end{array}$} & \multirow[b]{2}{*}{$\begin{array}{l}\text { Molecular } \\
\text { weight }\end{array}$} \\
\hline & thanol & Ethanol & $\begin{array}{l}\text { formal- } \\
\text { dehyde }\end{array}$ & & \\
\hline Polyporus & & & & & \\
\hline$s p$ & 1.52 & 10.0 & --- & 25.1 & 300,000 \\
\hline $\begin{array}{l}\text { Poria } \\
\text { contigua }\end{array}$ & 0.2 & 1.0 & 6.1 & 20.0 & 610,000 \\
\hline $\begin{array}{l}\text { Kloeckera } \\
\text { sp. } 2201\end{array}$ & 1.25 & 2.5 & --- & 11.0 & 570,000 \\
\hline $\begin{array}{l}\text { Kloeckera } \\
\text { sp. } 2201\end{array}$ & 0.44 & 2.5 & 2.4 & 8.5 & 673,000 \\
\hline $\begin{array}{l}\text { Hansenula } \\
\text { polymorpha }\end{array}$ & 0.08 & --- & 2.6 & -- & 617,000 \\
\hline $\begin{array}{l}\text { Hansenula } \\
\text { polymorpha }\end{array}$ & 0.23 & 4.4 & 2.6 & 11.3 & 669,000 \\
\hline $\begin{array}{l}\text { Hansenula } \\
\text { polymorpha }\end{array}$ & 1.3 & 7.2 & 4.7 & 56.3 & 616,000 \\
\hline $\begin{array}{l}\text { Candida } \\
\text { bonidini i }\end{array}$ & 2.0 & 2.62 & 5.7 & 3.4 & 600,000 \\
\hline Candida N16 & 2.12 & --- & --- & 3.5 & 210,000 \\
\hline Candida N16 & -- & --- & --- & & 600,000 \\
\hline Candida $25 \mathrm{~A}$ & 0.019 & 0.13 & --- & 2.8 & 520,000 \\
\hline $\begin{array}{l}\text { Pichia } \\
\text { pastoris }\end{array}$ & 1.4 & -- & --- & 11.9 & 675,000 \\
\hline Pichia sp. & 0.5 & -- & 3.5 & 6.6 & 300,000 \\
\hline
\end{tabular}


first enzyme in the dissimilatory pathway for the use of a sole carbon source for growth. The dissimilatory pathway for the oxidation of methanol by Pichia pastoris is shown in Fig $2[7]$. The location where harmful $\mathrm{H}_{2} \mathrm{O}_{2}$ is generated catalytically by one or more oxidases, then destroyed by another enzyme catalase, was determined to be an organelles by Duve, et al. [8]. They proposed the name 'peroxisome' for these structures.

Alcohol oxidase operates under a repression/depression type of metabolic control system. During the exponential growth of methyltrophic yeasts on glucose, peroxisomes are difficult to detect, and their physiological function is uncertain. However, when they are grown in media containing methanol as the carbon source, a number of large peroxisomes are present in the cells. If these methanol-grown cells are further transferred into glucose-containing media, the peroxisomes quickly disappear [9].

Alcohol oxidase is of considerable interest in biotechnological application because it displays rather broad specificity and stability. However, the activity decreases precipitously with alcohol chain length beyond ethanol [10-12]. Several researchers [13-17] have investigated potential uses, including; (1) as enzyme-based electrodes in analytical assay, (2) as an oxygen scavenger, (3) as a food additive, flavor or fragrance, (4) for sterilization of heat- or radiation- sensitive materials through the release of formaldehyde, and (5) as an ethanol recovery system. 


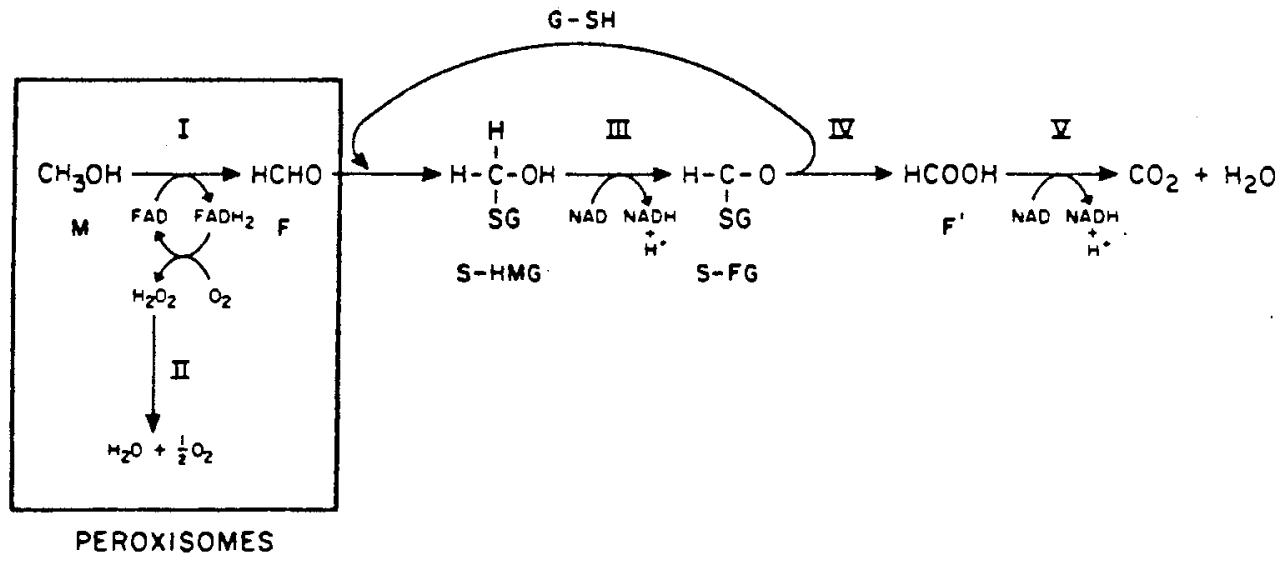

\footnotetext{
I: Alcohol oxidose

II: Colalose

III: Formaldehyde dehyarogenose

II: S-Formylglutophione hydrolose

$\boldsymbol{Z}$ : Formote dehydrogenose
}

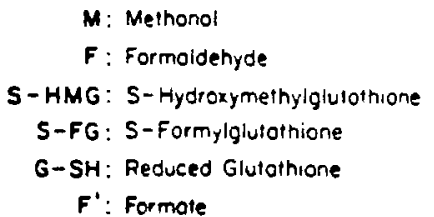

M: Methorol$$
\text { - HMG: S-Hydroxymethylglulothione }
$$$$
\text { S-FG: S-Formylglutatione }
$$

$F^{\prime}$ : Formate

Figure 2. Pathway for the oxidation of methanol by P. pastoris. [7] 
The Enzymatic Reaction Mechanism

The enzymatic reactions are:

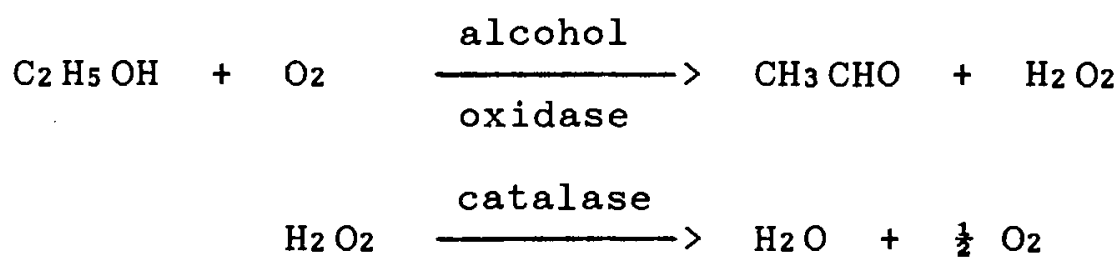

In this reaction, ethanol is converted to acetaldehyde in the presence of alcohol oxidase, and the product, hydrogen peroxide, is decomposed by the action of the enzyme catalase into oxygen and water.

The overall reaction is:

$\mathrm{C}_{2} \mathrm{H}_{5} \mathrm{OH}+\frac{1}{2} \mathrm{O}_{2} \stackrel{\text { enzymes }}{>} \mathrm{CH}_{3} \mathrm{CHO}+\mathrm{H}_{2} \mathrm{O}$

A number of investigators $[18-20]$ has reported that the hydrogen peroxide is highly inhibitory to the enzyme activity. Since the amount of catalase in the peroxisome is far larger than that of alcohol oxidase, the extremely toxic substance, $\mathrm{H}_{2} \mathrm{O}_{2}$, is readily disposed and the inhibition on alcohol oxidase is rarely found. The rate determining reaction is the oxidation of ethanol by alcohol oxidase.

\section{Operating Variables Inside the Bioreactor}

The significant factors influencing the performance of a liquid-phase bioreactor might be temperature, $\mathrm{pH}$, oxygen limitation and inactivation of alcohol oxidase activity. These variables are discussed as follows:

<1> Temperature effect: At elevated temperature enzymatic reactions rates can be accelerated and enzyme 
contamination reduced [21]. However, high temperature will inactivate the enzyme, especially for soluble alcohol oxidase which shows more temperature sensitivity than the immobilized form. Therefore, the choice of operating temperature should be determined according to the specific environment. The optimal temperature for Pichia pastoris non-growing whole cells is in the range from $30^{\circ} \mathrm{C}$ to $37^{\circ} \mathrm{C}$ $[11,16,19,23,24]$. Table 5 is a list of the optimal temperatures and $\mathrm{pH}$ values for different methyltrophic yeasts.

<2> $\mathrm{pH}$ effect: $\mathrm{pH}$ is always a determining factor for cell cultures. In the initial stage of this biological reaction, hydrogen peroxide is produced with the oxidation of ethanol to acetaldehyde, thus $\mathrm{pH}$ is expected to decrease slightly due to a high initial production rate. However, when steady state is reached, the $\mathrm{pH}$ value should be nearly unchanged.

<3> Oxygen limitation effect: Relatively little is known about the kinetics of alcohol oxidase with respect to its second substrate oxygen. In the case of $H$. polymorpha and Pichia pastoris, the enzyme hasn't much affinity for oxygen, a property shared by other hydrogen peroxideproducing oxidases (Table 4) [6]. Thus, in the affinity of the enzyme for the alcohol oxidase, oxygen concentration plays an important role. This means that the enzyme has its maximal activity when the aqueous environments are saturated with pure oxygen [6]. Most of the Km estimations in Table 6 were performed with colorimetric assays. The real oxygen 
TABLE 5

THE OPTIMAL TEMPERATURE \& $\mathrm{pH}$ FOR SOME METHANOL-GROWN CELLS*

\begin{tabular}{lcc}
\hline Methanol-Grown Cell & Temperature $\left({ }^{\circ} \mathrm{C}\right)$ & $\mathrm{pH}$ \\
\hline H. Polymorpha & 45 & 7.5 \\
Kloeckera sp. & 35 & $8.0-9.0$ \\
$C$. boidinit $S 2$ AOU-1 & 27 & $7.5-8.0$ \\
$P$. pastoris & 32 & 8.0 \\
$P$. pastoris & 45 & 8.0 \\
$P$. pastoris & 37 & 7.5 \\
\hline
\end{tabular}

* References $11,16,19,23$, and 24 . 
concentration in the reaction mixture was not reported. As a result, the apparent $\mathrm{Km}$ values listed in Table 6 cannot be compared directly, as suggested by Duev [8]. According to researchers at Phillips Petroleum Company [22], pure oxygen is likely to tear down the cell wall, and thus offers a better catalytic reaction area between enzyme and substrate. However, enzyme stability is greatly reduced, probably due to the simultaneous inhibition by acetaldehyde and hydrogen peroxide. Thus far, most workers have investigated the production of acetaldehyde by methyltrophic yeasts with excess pure oxygen, and extended alcohol oxidase stability in operation is seldom mentioned.

<4> Inactivation effect: There are several factors that will inactivate the alcohol oxidase, namely; ethanol, hydrogen peroxide, acetaldehyde and catabolite inactivation. Since the peroxisome of Pichia pastoris whole cells are full of catalase, the hydrogen peroxide inhibition might not have a critical effect on this enzyme. From several studies [25-27], ethanol inhibition appears only slightly (in the concentration range from $10 \mathrm{~g} / \mathrm{L}$ to $60 \mathrm{~g} / \mathrm{L}$ ). However, acetaldehyde might have a significant affect on alcohol oxidase inactivation. Duff and Murray showed that even $1.0 \mathrm{~g} / \mathrm{L}$ initial acetaldehyde concentration would cause $8 \%$ oxidase inhibition and $4.0 \mathrm{~g} / \mathrm{L}$ would cause $50 \%$ alcohol oxidase inhibition [16]. Fig 3 is adapted from the data of Duff and Murray.

Regarding catabolite inactivation, no report of this 
TABLE 6

APPARENT $\mathrm{Km}$ VALUES OF VARIOUS HYDROGEN

PEROXIDE-PRODUCING OXIDASES [6]

\begin{tabular}{llll}
\hline Enzyme & EC number & Source & $\mathrm{Km}(\mathrm{mM})$ \\
\hline Glucose oxidase & 1.1 .3 .4 & Aspergillus niger & 0.20 \\
$\begin{array}{l}\text { Gulunolactone } \\
\text { oxidase }\end{array}$ & 1.1 .3 .8 & Rat liver & 0.20 \\
Alcohol oxidase & 1.1 .3 .13 & Pichia pastoris & 1.0 \\
Alcohol oxidase & 1.1 .3 .13 & H. polymorpha & 0.4 \\
Xanthine oxidase & 1.2 .3 .2 & Bovine milk & 0.24 \\
$\begin{array}{l}\text { D-Amino acid } \\
\text { oxidase }\end{array}$ & 1.4 .3 .3 & Hog kidney & 0.18 \\
Amine oxidase & 1.4 .3 .4 & Candida boidinit & 0.09 \\
Urate oxidase & 1.7 .3 .3 & $\begin{array}{l}\text { Bacillus } \\
\text { fastidiosus }\end{array}$ & 1.0 \\
\hline
\end{tabular}


influence on Pichia pastoris was published, however, when C. boidinii and $H$. polymorpha were transferred from the late-exponential growth phase into ethanol-containing media, both catalase and alcohol oxidase activities decreased dramatically. Six hours after the transfer, alcohol oxidase activity was no longer detectable. This inactivation was due, at least partially, to the over-production of acetaldehyde when methanol-grown yeast cultures had been changed to ethanol medium [16]. 
CHAPTER III

\title{
EXPERIMENTAL APPARATUS, PROCEDURES
}

AND ANALYTICAL METHODS

\section{Experimental Apparatus}

\begin{abstract}
Two apparatuses were used to study the enzymatic reaction of converting ethanol to acetaldehyde using Pichia pastoria whole yeast cells in liquid phase. The liquid phase bioreactor is similar to a CSTR (continuous-flow stirred-tank reactor), however, it was operated in semi-batch mode. This research project was mainly divided into two stages. In the first stage, a 2-liter glass fermentor, with $700 \mathrm{ml}$ working volume was used to explore the general behavior of this enzymatic reaction under different operating conditions, such as $\mathrm{pH}$, temperature, agitation speed, substrate feed rate, etc. In the second stage, a 5-1iter New Brunswick fermentor, with 2-liter working volume, was adapted to improve the mixing problems in the former reactor. In addition, the 5-liter reactor was mounted with a $\mathrm{pH}$ meter and oxygen probe to continuously monitor $\mathrm{pH}$ and dissolved oxygen concentration. This resulted in a more stable environment for the cells. Figs 4 and 5 are the schematic diagrams for these two bioprocesses. The major components are discussed briefly.
\end{abstract}




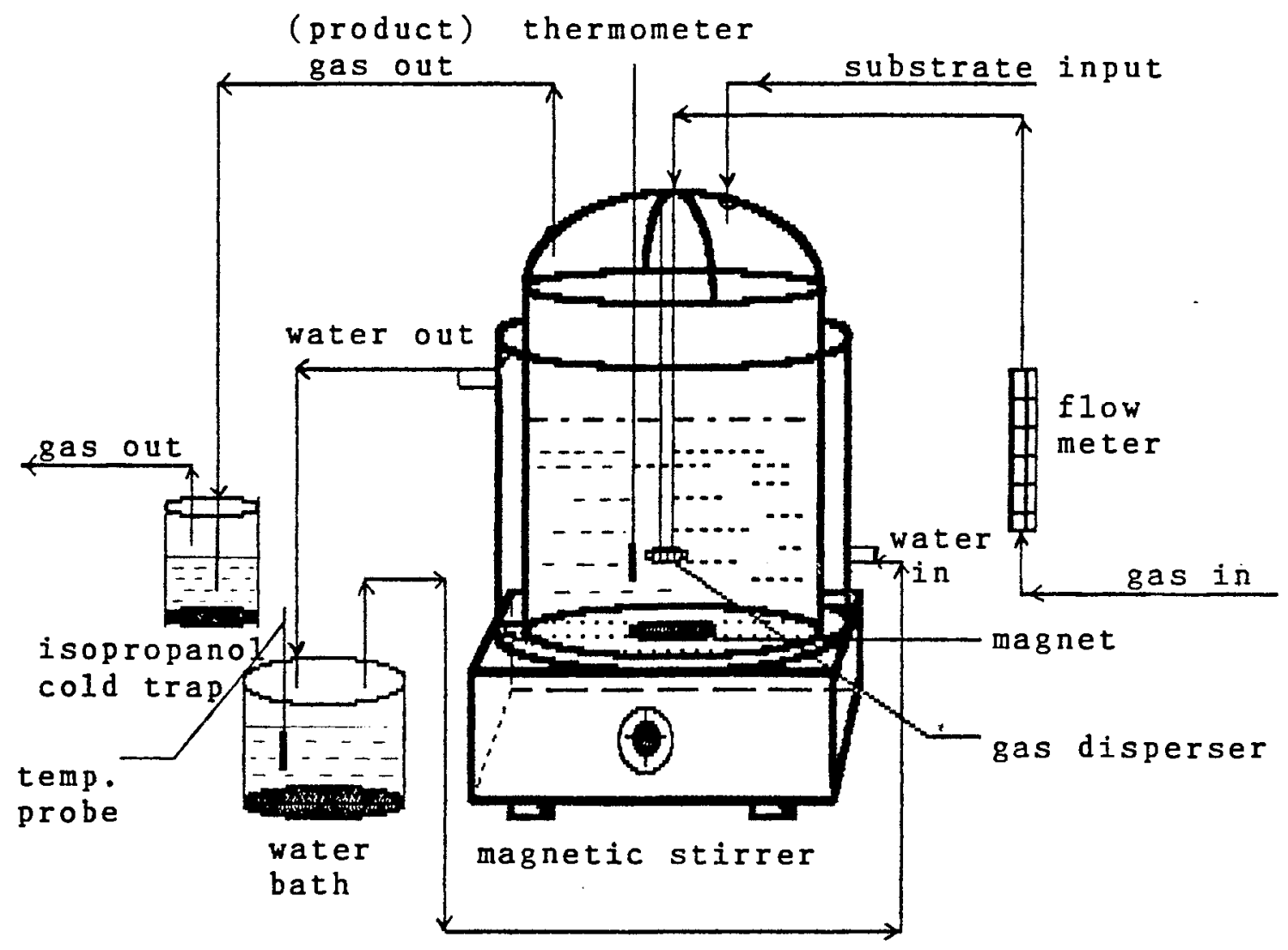

Figure 4. Bioreactor instrumentation for converting ethanol to acetaldehyde (first stage: 2-liter fermentor). 


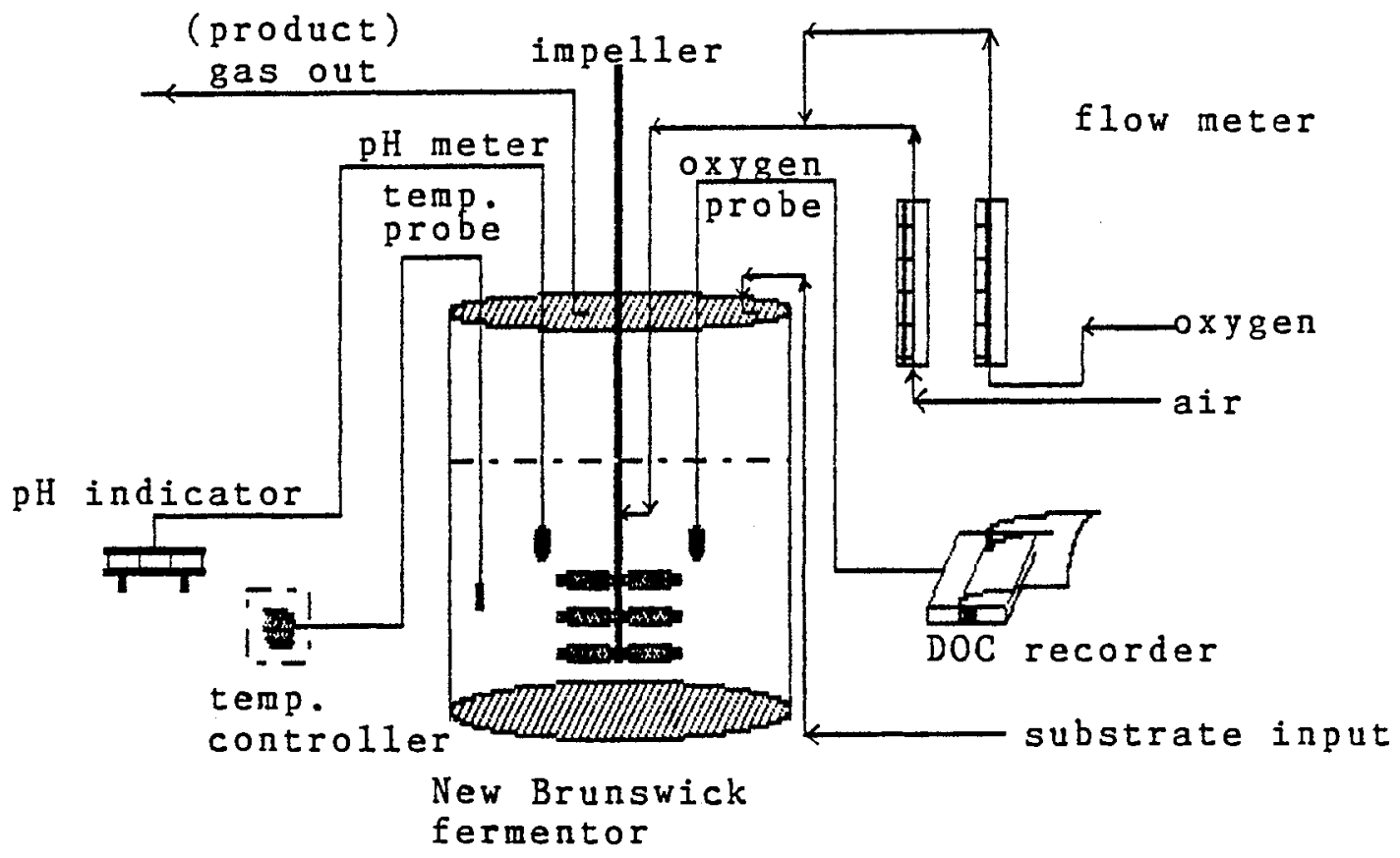

Figure 5. Schematic diagram of acetaldehyde bioreactor system (second stage: 5-liter fermentor). 
$\mathrm{pH}$ Meter

The $\mathrm{pH}$ electrode is manufactured by New Brunswick Scientific Inc. It is a single unit glass-reference electrode design with an accuracy of $\pm 0.05 \mathrm{pH}$. In this study, it was combined with a $\mathrm{pH}$ meter/controller, made by Cole-Parmer Instrument Inc., to progressively observe and govern the $\mathrm{pH}$ in the reaction medium.

\section{Oxygen Probe}

The oxygen probe is fabricated by New Brunswick Scientific Inc. and connected to a recorder made by Shimaza, Japan. It is a galvanic (potentiometric) type. The electrode measures the partial pressure (or activity) of the dissolved oxygen and not the dissolved oxygen concentration. The electrode internals are separated from the medium by an oxygen-permeable membrane. The reduction of oxygen takes place at the cathode surface.

Cathode $\quad \frac{1}{2} \mathrm{O}_{2}+\mathrm{H}_{2} \mathrm{O}+2 \mathrm{e}^{-} \stackrel{\text { pt }}{\longrightarrow} 2 \mathrm{OH}^{-}$

The reaction at the anode

Anode $\quad \mathrm{Pb} \longrightarrow \cdot \mathrm{Pb}^{2+}+2 e^{-}$

completes the cell. A small amount of current is drawn to provide a voltage measurement which in turn is correlated to the oxygen flux reaching the cathode surface.

\section{Flow Meter}

The flowmeter is a New Brunswick Scientific Inc, model 701. This instrument allows a range of air flow rate from 
0.5 to 15 liter/min. Different kinds of gas need only a correlation factor.

Nitrogen and Isopropanol Cold Trap

Initially, an isopropanol cold trap was used in an effort to catch the highly volatile product, acetaldehyde. However, the recovery efficiency observed was not satisfactory (only $6 \%$ to $10 \%$ ) and was abandoned. Next, a nitrogen cold trap insulated by glass-fiber material was tried with the inside temperature as low as $-75^{\circ} \mathrm{C}$. The acetaldehyde condensed was estimated to be at least $85 \%$ acetaldehyde produced in the first 4 hours. But the total recovery efficiency was only about $9 \%$ for the whole process. It might be explained as (1) the temperature of the nitrogen cold trap increases gradually due to the loss of liquid nitrogen during the extended operating, (2) the warm gas $\left(\approx 30^{\circ} \mathrm{C}\right)$ continuously flows through the condensate in the liquid nitrogen cold trap, and carries the acetladehyde away if the cold trap cannot maintained the low temperature constant.

\section{Temperature Controller}

In the first stage of this research, a waterbath was used to control the temperature with an accuracy of $\pm 0.5^{\circ} \mathrm{C}$. The New Brunswick fermentor has hollow baffle heat exchanger which controls temperature by water circulating through the reactor baffles. The accuracy was also $\pm 0.5^{\circ} \mathrm{C}$. 
Description of System Process

This enzymatic process was mainly composed of the units described above (refer to Fig 5). The vessel was initially filled with water, whole cells and ethanol; usually $10 \%$ cells, $10 \%$ ethanol and $80 \%$ distilled water. The substrate, ethanol, was added to the reactor intermittently to maintain an ethanol concentration at $\pm 10 \%$ of the initial value. The overhead vapor products, ethanol, water and acetaldehyde, were carried out continuously by gas flow through the vessel and collected in the nitrogen cold trap. The gas was pure air, pure oxygen or a mixture of both. An oxygen probe monitored the enzyme activity. $\mathrm{pH}$ was monitored and adjusted manually through the help of the $\mathrm{pH}$ indicator. Temperature was regulated at $30^{\circ} \mathrm{C}$. Furthermore, impeller speed was controlled at $600 \mathrm{rpm}$.

This liquid phase bioreactor is not new, others have examined the removal of alcohol vapor from a fermentor, however, not much success had been achieved. For the acetaldehyde reaction, there is a distinct advantage with regard to product vapor pressure. The boiling point of acetaldehyde is $21^{\circ} \mathrm{C}$, substantially below the boiling points of ethanol and water. This allows the liquid phase reactor to act as the first separation stage for product purification. Overall, this bioreactor offers a very clean scheme, the only substrate is ethanol and the products containing only volatile acetaldehyde, unreacted ethanol and water. 


\section{Experimental Procedure}

The two aspects: (1) Calibration and (2) Operation procedure are discussed briefly as follows.

\section{Calibration Procedure}

\section{Flowmeter Calibration}

The flowmeter with the New Brunswick Fermentor was calibrated for the flow of air at atmospheric pressure and $23^{\circ} \mathrm{C}$. However, other gases could be metered through the flowmeter according to the correction factor in Table 15 in Appendix A. Multiplication of the flowmeter reading by the correction factor for the specific gas being used would provide the corrected flow rate.

$\mathrm{pH}$ meter Calibration

Three standard buffer solutions, $\mathrm{pH}$ at $4.0,7.0$ and 10.0, were made by using buffer powder from Micro Essential Laboratory Inc., New York. The $\mathrm{pH}$ meter was calibrated before all experiments.

\section{Chromatograph Calibration}

Four diluted solutions of ethanol, 1, 2, 4 and 10 percent by volume, were prepared with distilled water. One pl sample volume of each solution was analyzed by GC. The ethanol peak area obtained was plotted against volume percent of ethanol in each sample. The results were the 
average for at least three injections (shown in Table 16). The calibration curve is plotted in Fig 27, Appendix B. Chromatography grade acetaldehyde solutions of $1 \%, 2 \%$, $4 \%$ and $10 \%$ by volume were prepared and calibrated with the procedures described above. The calibration curve is plotted in Fig 27, Appendix B.

\section{Operating Procedure}

(1) The $\mathrm{pH}$ meter, indicator and oxygen probe (if needed) were set up and calibrated to the range of interest.

(2) The desired amount of buffer solution, $\mathrm{pH}$ at $7.0-8.0$, was added to the fermentor and heated to $30^{\circ} \mathrm{C}$. The gas (air, oxygen or both) flow rate was controlled at 2 liters/min and was stabilized by a gauge pressure regulator before it entered the reactor.

(3) After the temperature was stable and other operation conditions were ready to go, ethanol solution and yeast cell broth were put in the fermentor to start the enzymatic reaction.

(4) Samples were withdrawn and analyzed regularly to measure the extent of reaction.

(5) Distilled water and ethanol were added intermittently to keep the liquid level and ethanol concentration in a reasonable range $( \pm 10 \%$ of initial value). 
Materials and Methods

\section{Microorganisms}

All Pichia pastoris cells used in this study were obtained from Phillips Petroleum Company. Most cells were frozen at $-10^{\circ} \mathrm{C}$ before use.

\section{Buffer Solution}

The buffer solution was a mixture of potassium phosphate dibasic and monobasic in different ratios in order to give the desired $\mathrm{pH}$ value, which ranged from 7.0 to 8.0 .

\section{GC Analyses}

Samples taken from the reaction medium were cooled at $-15^{\circ} \mathrm{C}$ for one minute, centrifuged immediately for two minutes at $9000 \mathrm{rpm}$ and analyzed by GC (gas chromatograph). Products taken from the nitrogen or isopropanol cold trap were analyzed directly. Samples were assayed using a Hewlett Packard 5880A gas chromatograph fitted with a flame ionization detector. A one meter column with Chromasorb $80 / 100$ mesh as the packing material was used. The gas chromatography settings were: carrier nitrogen, $30 \mathrm{ml} / \mathrm{min}$; air, $350 \mathrm{ml} / \mathrm{min}$; hydrogen, $30 \mathrm{ml} / \mathrm{min}$; oven temperature, $50^{\circ} \mathrm{C}$; injector, $150^{\circ} \mathrm{C}$; and detector, $200^{\circ} \mathrm{C}$.

\section{Biomass}

Biomass was determined by dry cell weight. Six ml 
reaction medium, before and after the experiment, was put in a test tube, dried in an oven at $120^{\circ} \mathrm{C}$ until no change in weight was observed. The net dry cell weight was determined by difference.

$$
\text { DCW }=(\text { tube weight }+ \text { DCW })-(\text { tube weight })
$$

It was found that the loss of biomass is negligible ( $1 \%$ to $3 \%)$. 
CHAPTER IV

EXPERIMENTAL RESULTS

\author{
First Stage : Preliminary Study \\ (2-liter glass fermentor)
}

The primary object of this stage was to study the main factors affecting the behavior of bioconversion of ethanol to acetaldehyde in a liquid phase reactor. Six experiments were performed and the operating conditions are listed in Table 7 .

The initial acetaldehyde production rate was defined as the amount of acetaldehyde per liter produced in liquid phase in the first hour. The effect of substrate concentration on the initial acetaldehyde production rate ( $g$ AcetH/L/h) of Pichia pastoris whole cells was studied at a fixed cell concentration ( $55 \mathrm{~g}$ dried cell weight/L). The results are shown in Fig 6 . The initial acetaldehyde production increases with ethanol concentration, rising to a maximum near $10 \%$ ethanol and then falling at higher ethanol concentrations. Attention should be paid to the different working volumes of reaction, however, with the same air flow rate in these experiments. If oxygen concentration was critical to the reaction, it would explain why the reaction rate in Expt 1 was low compared with the others. 
TABLE 7

SUMMARY OF EXPERIMENTAL OPERATING CONDITIONS

\begin{tabular}{|c|c|c|c|c|c|c|c|}
\hline Expt & $\mathrm{pH}$ & $\begin{array}{l}\text { Temp } \\
\left({ }^{\circ} \mathrm{C}\right)\end{array}$ & $\begin{array}{l}\text { Air Rate } \\
(1 / \mathrm{min})\end{array}$ & $\begin{array}{l}\mathrm{O}_{2} \text { Rate } \\
(1 / \mathrm{min})\end{array}$ & $\begin{array}{c}\text { Stirrer } \\
\text { (rpm) }\end{array}$ & $\begin{array}{c}\mathrm{DCW} \\
(\mathrm{g} / \mathrm{L})\end{array}$ & $\begin{array}{c}\text { Ethanol } \\
(\mathrm{g} / \mathrm{L})\end{array}$ \\
\hline 1 & $5.5-6.0$ & 30 & 2.0 & --- & 600 & 55 & 40 \\
\hline 2 & $5.5-6.0$ & 30 & 2.0 & --- & 600 & 55 & 80 \\
\hline 3 & $5.5-6.0$ & 30 & 2.0 & --- & 600 & 55 & 160 \\
\hline 4 & $5.5-6.0$ & 30 & $2.0-3.5$ & --- & 600 & 55 & 80 \\
\hline 5 & $5.5-6.0$ & 30 & $2.0-4.0$ & --- & 600 & 55 & 80 \\
\hline 6 & $5.5-6.0$ & 30 & $2.0-3.5$ & --- & 600 & 55 & 80 \\
\hline 7 & $7.0-7.3$ & 30 & 2.0 & --- & 200 & 9.9 & 80 \\
\hline 8 & $7 \cdot 1-7 \cdot 3$ & 30 & 2.0 & --- & 200 & 9.9 & 80 \\
\hline 9 & $7.5-7.6$ & 30 & 2.0 & --- & 200 & 9.9 & 80 \\
\hline 10 & $7.5-7.6$ & 30 & 2.0 & --- & 200 & 9.9 & 80 \\
\hline 11 & $7.5-7.6$ & 30 & 1.0 & 1.0 & 200 & 9.9 & 80 \\
\hline 12 & $7.5-7.6$ & 30 & 0.5 & 1.5 & 200 & 9.9 & 80 \\
\hline 13 & $7.5-7.6$ & 30 & 1.0 & 3.0 & 200 & 9.9 & 80 \\
\hline 14 & $7 \cdot 5-7 \cdot 6$ & 30 & 2.0 & --- & 200 & 9.9 & 80 \\
\hline 15 & $7.5-7.6$ & 30 & 2.0 & --- & 200 & 9.9 & 40 \\
\hline 16 & $7.5-7.6$ & 30 & 2.0 & --- & 200 & 9.9 & 120 \\
\hline
\end{tabular}




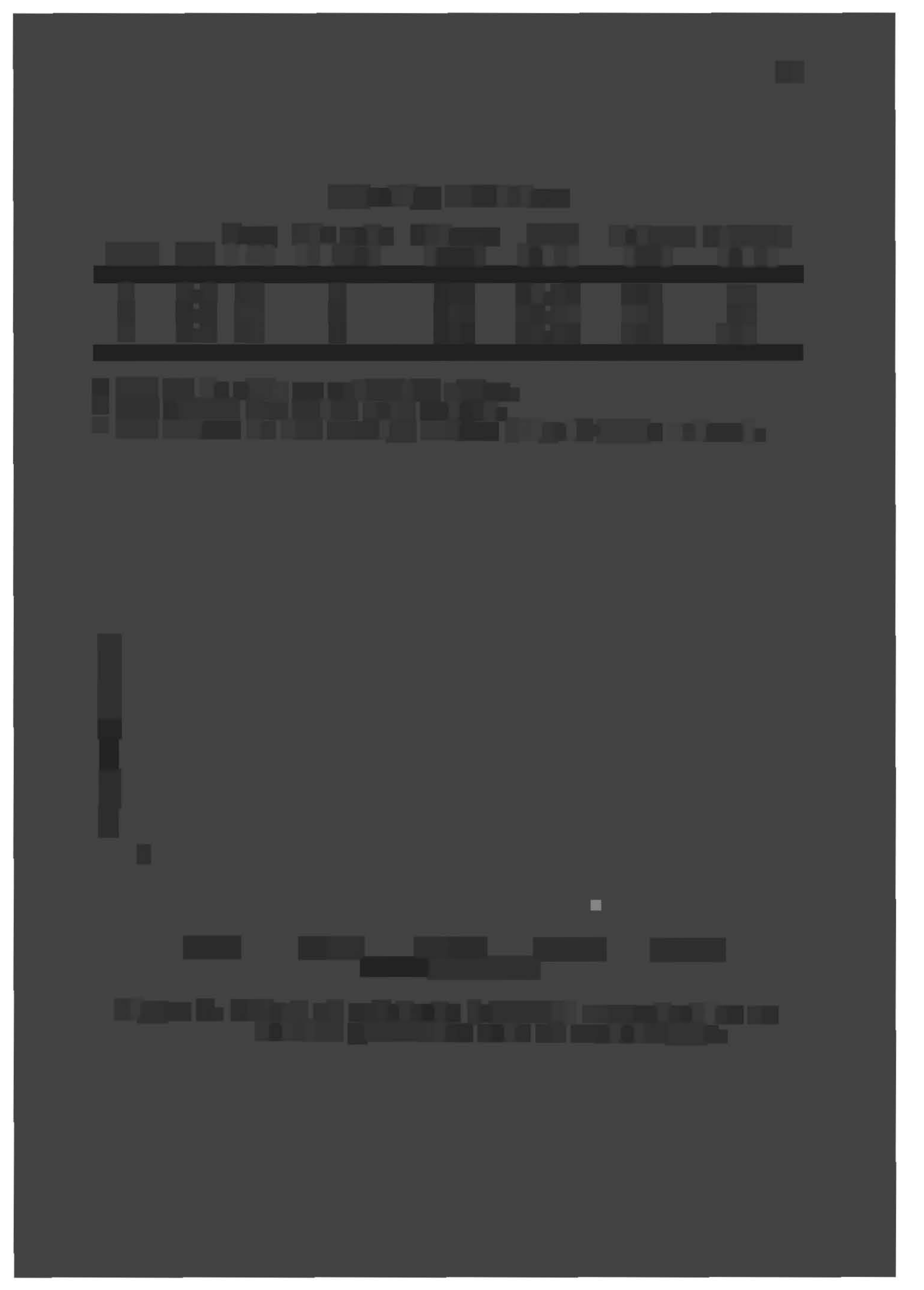




\begin{tabular}{cccccccc} 
Expt & pH & $\begin{array}{c}\text { Temp } \\
\left({ }^{\circ} \mathrm{C}\right)\end{array}$ & $\begin{array}{c}\text { Air rate } \\
(1 / \mathrm{min})\end{array}$ & $\begin{array}{c}\text { Stirrer } \\
(\mathrm{rpm})\end{array}$ & $\begin{array}{c}\text { DCW } \\
(\mathrm{g} / \mathrm{L})\end{array}$ & $\begin{array}{c}\text { Volume } \\
(\mathrm{ml})\end{array}$ & $\begin{array}{c}\text { Ethanol } \\
(\mathrm{g} / \mathrm{L})\end{array}$ \\
\hline 1 & 5.5 & 30 & 2 & 600 & 47.48 & 695 & 40 \\
2 & 5.5 & 30 & 2 & 600 & 55.00 & 300 & 80 \\
3 & 5.5 & 30 & 2 & 600 & 55.00 & 496 & 160 \\
\hline
\end{tabular}

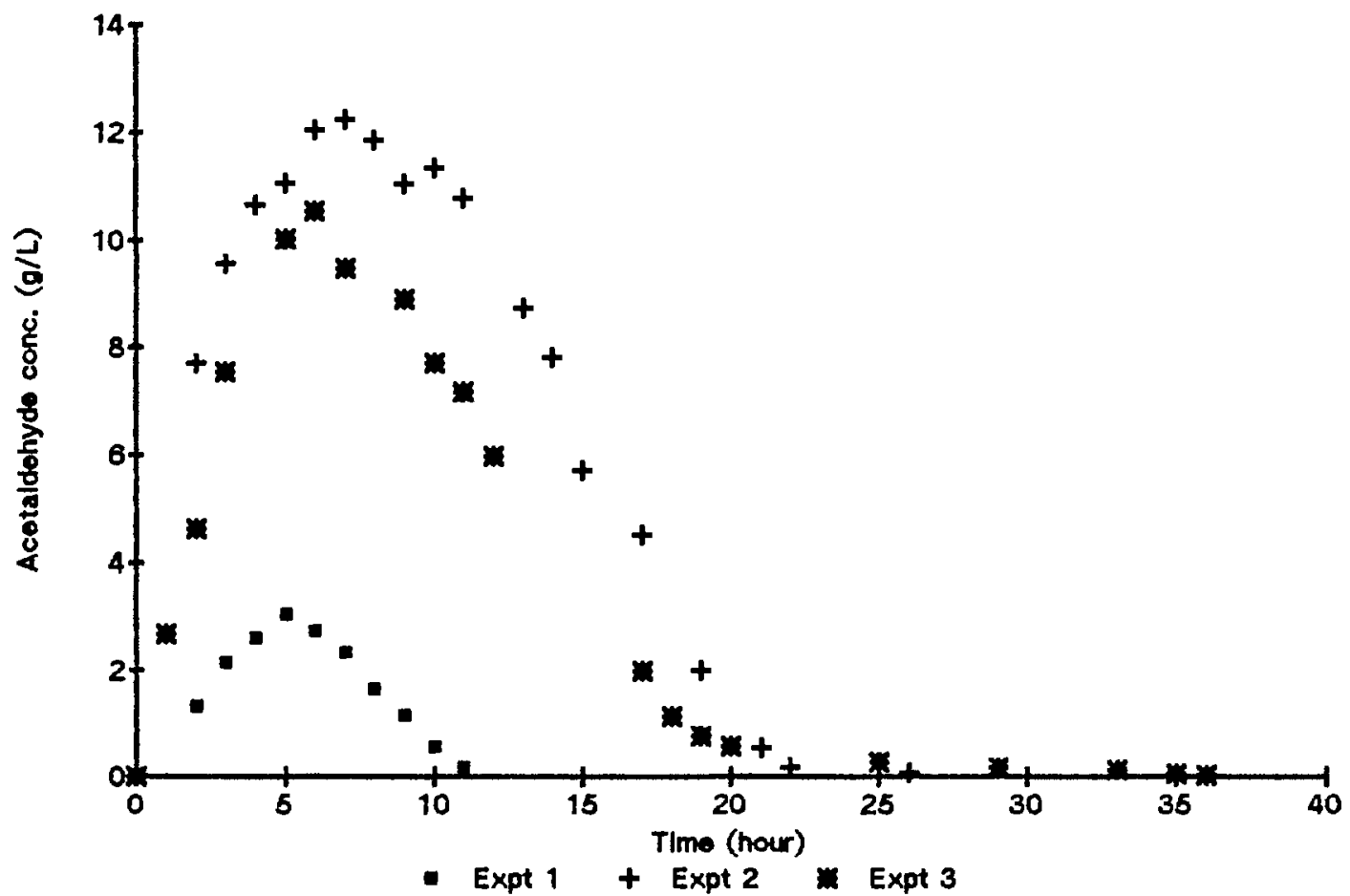

Figure 7. Acetaldehyde concentration profile in fermentor under different substrate concentrations. 
The concentration profiles of acetaldehyde in the fermentor are shown in Fig 7. Apparently, this enzymatic reaction yields better acetaldehyde production and longer alcohol oxidase activity with $10 \%(80 \mathrm{~g} / \mathrm{L})$ ethanol concentration.

Acetaldehyde is well known to have a tremendous impact on alcohol oxidase, even a $1.0 \mathrm{~g} / \mathrm{L}$ initial acetaldehyde concentration would cause $8 \%$ oxidase inhibition and $4.0 \mathrm{~g} / \mathrm{L}$ would cause $50 \%$ oxidase inhibition (refer to Chapter 2 ). Expts 4 and 5 were performed in an attempt to keep the activity of alcohol oxidase for longer period by adjusting the air flow rate, stripping acetaldehyde out of the reactor, and thus reduce the inhibition of whole cells by acetaldehyde in solution. It was hoped to keep acetaldehyde concentration below $1.0 \%$ by volume $(7.8 \mathrm{~g} / \mathrm{L})$, however, the initial acetaldehyde production was so high that acetaldehyde concentration reached $4.0 \mathrm{~g} / \mathrm{L}$ in the first hour and exceeded $1 \%$ after 3 hours. It is difficult to adjust the air flow rate to keep the acetaldehyde concentration below $1.0 \%$ because of the time delay in the air pipeline. When compared to Expt 2, Expts 4 and 5 didn't show great improvement but did prolong the reaction time for about eight hours longer than Expt 2 (Fig 8). There are two possibilities for this: (1) the end-product inhibition (acetaldehyde) is not a dominant factor, and (2) oxygen concentration limits the reaction rate and thus causes Expts 3,4 and 5 to have almost the same production rate. It is easy to prove that hypothesis (1) is not reasonable from the 


\begin{tabular}{cccccccc} 
Expt & pH & $\begin{array}{c}\text { Temp } \\
\left({ }^{\circ} \mathrm{C}\right)\end{array}$ & $\begin{array}{c}\text { Air rate } \\
(1 / \mathrm{min})\end{array}$ & $\begin{array}{c}\text { Stirrer } \\
(\mathrm{rpm})\end{array}$ & $\begin{array}{c}\text { DCW } \\
(\mathrm{g} / \mathrm{L})\end{array}$ & $\begin{array}{c}\text { Volume } \\
(\mathrm{ml})\end{array}$ & $\begin{array}{c}\text { Ethanol } \\
(\mathrm{g} / \mathrm{L})\end{array}$ \\
\hline 2 & 5.5 & 30 & 2.0 & 600 & 55 & 300 & 80 \\
4 & 5.5 & 30 & $2.0-4.0$ & 600 & 55 & 300 & 80 \\
5 & 5.5 & 30 & $2.0-3.5$ & 600 & 55 & 300 & 80 \\
\hline
\end{tabular}

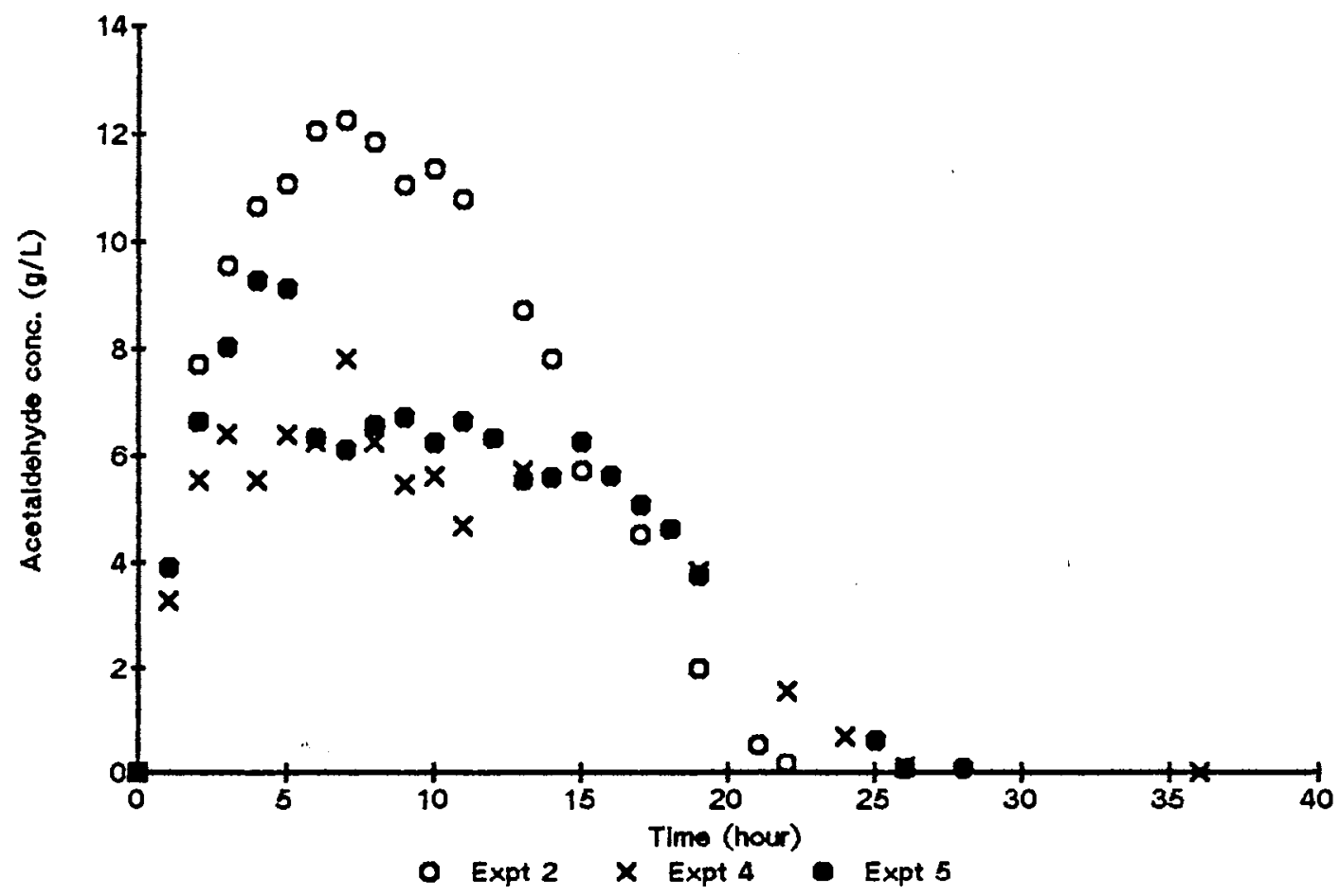

Figure 8. Acetaldehyde concentration profile in fermentor for Expts 2, 4 and 5 . Expts 4 and 5 were with a varied air flow rate in an attempt to make enzyme activity last longer than Expt 2 . 
Iiterature. Expt 6 was operated with the same conditions as Expt 4 and 5 except that air was replaced with pure oxygen. The result was astonishing (Fig 9). The acetaldehyde concentration reached $11.0 \mathrm{~g} / \mathrm{L}$, twice that in Expt 5 in the first hour, and the reaction time lasted for 100 hours with measurable acetaldehyde. Fig 10 is a comparison of Expt 3 with a normal gas disperser and another experiment (Expt $3 a$ ) at the same conditions as Expt 3 but with a broken sparger. Obviously, oxygen concentration plays an important role in the acetaldehyde bioreaction. However, researchers at Phillips Petroleum Company found that pure oxygen would damage cell structures and suggested using a mixture of air and oxygen or just pure air instead of pure oxygen. Two hypotheses were proposed: (1) the mixing effect was not good, and (2) the whole cell concentration was too high. So, a 5-1iter New Brunswick fermentor was borrowed from Phillips Petroleum Company to overcome the mixing problem and the cell concentration was cut to $1 / 5$ of Expt 6 to test these two hypotheses.

\section{Second Stage: Variable Investigation (5-liter New Brunswick fermentor)}

A 5-liter New Brunswick fermentor with 2-liter working Iiquid volume was used to overcome the mixing inefficiency observed in the first stage, and explore the variables effecting the acetaldehyde bioreaction.

In previous experiments, $\mathrm{pH}$ changes were not monitored 


\begin{tabular}{cccccccc} 
Expt & pH & $\begin{array}{c}\text { Temp } \\
\left({ }^{\circ} \mathrm{C}\right)\end{array}$ & $\begin{array}{l}\text { Gas rate } \\
(1 / \mathrm{min})\end{array}$ & $\begin{array}{c}\text { Stirrer } \\
(\mathrm{rpm})\end{array}$ & $\begin{array}{c}\text { DCW } \\
(\mathrm{g} / \mathrm{L})\end{array}$ & $\begin{array}{c}\text { Volume } \\
(\mathrm{ml})\end{array}$ & $\begin{array}{c}\text { Ethanol } \\
(\mathrm{g} / \mathrm{L})\end{array}$ \\
\hline 4 & 5.5 & 30 & $2.0-3.5 \mathrm{a}$ & 600 & 55 & 300 & 80 \\
5 & 5.5 & 30 & $2.0-4.0 \mathrm{~b}$ & 600 & 55 & 300 & 80 \\
6 & 5.5 & 30 & $2.0-3.5 \mathrm{c}$ & 600 & 55 & 300 & 80 \\
\hline
\end{tabular}

+ : The gas in Expts 4 and 5 was air but it was pure oxygen in Expt 6 .

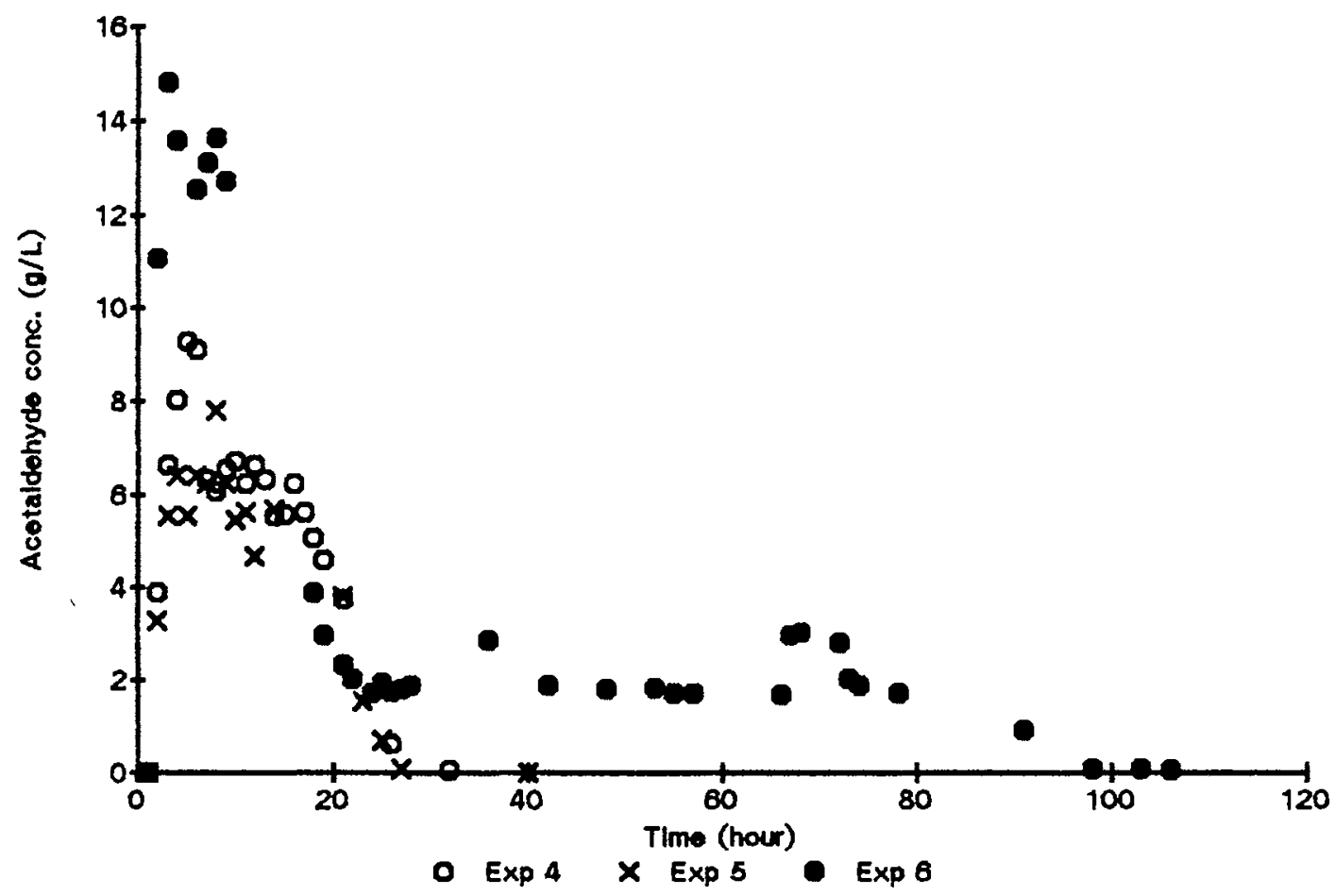

Figure 9. Acetaldehyde concentration profile in fermentor under controlled gas flow rate. The biomass concentration was $50 \%$ cell broth in fermentor (average $\mathrm{DCW}=55 \mathrm{~g} / \mathrm{L}$ ) 
Operating Conditions

\begin{tabular}{lccccccc} 
Expt & pH & $\begin{array}{c}\text { Temp } \\
(\cdot \mathrm{C})\end{array}$ & $\begin{array}{c}\text { Air rate } \\
(1 / \mathrm{min})\end{array}$ & $\begin{array}{c}\text { Stirrer } \\
(\mathrm{rpm})\end{array}$ & $\begin{array}{c}\text { DCW } \\
(\mathrm{g} / \mathrm{L})\end{array}$ & $\begin{array}{c}\text { Volume } \\
(\mathrm{ml})\end{array}$ & $\begin{array}{c}\text { Ethanol } \\
(\mathrm{g} / \mathrm{L})\end{array}$ \\
\hline 3 & 5.5 & 30 & 2.0 & 600 & 55 & 300 & 80 \\
$3 \mathrm{a}$ & 5.5 & 30 & 2.0 & 600 & 55 & 300 & 80 \\
\hline
\end{tabular}

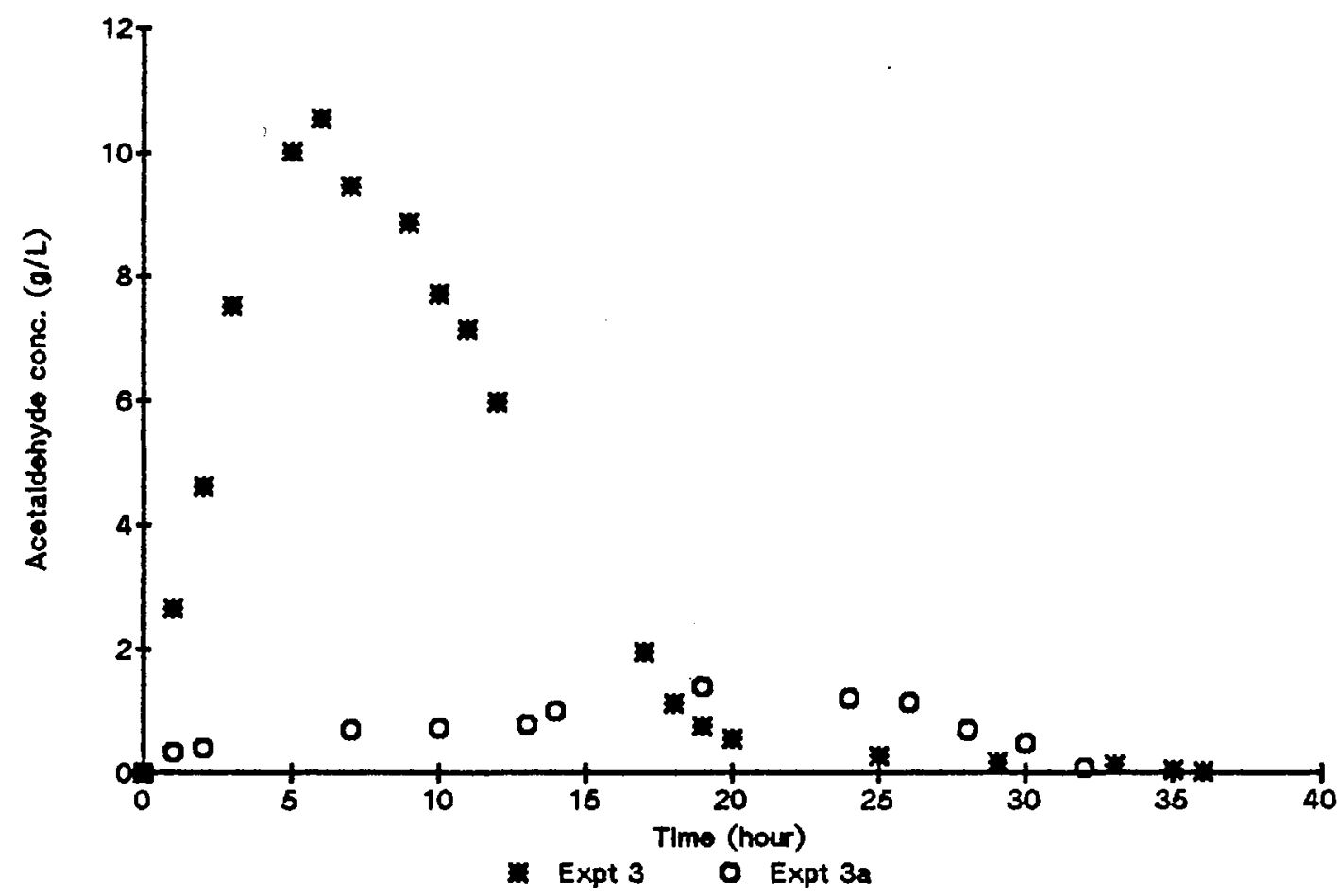

Figure 10. A comparison of acetaldehyde production between Expt 3 (with normal gas dispersor) and Expt $3 a$ with a broken gas dispersor). 
while the experiments were in progress. Although a difference in initial and final $\mathrm{pH}$ had changes around 0.5-1.0. Expts 7,8 and 9 were performed to see the $\mathrm{pH}$ influence on reaction. The biomass concentration had been reduced to 9.9 grams dried cell weight per liter. The results were shown on Fig 11 . Expts 8 and 9 , with well controlled $\mathrm{pH}$, showed longer reaction time (over 200 hours) than Expt 4 or Expt 5 (only 36 hours); but the initial acetaldehyde production rate (only $0.25 \mathrm{~g} / \mathrm{L}$ in Expt 8 and $0.47 \mathrm{~g} / \mathrm{L}$ in Expt 9) was less than Expt $4(3.9 \mathrm{~g} / \mathrm{L})$ or Expt 5 $(3.2 \mathrm{~g} / \mathrm{L})$. Regarding overall acetaldehyde production, which is proportional to the area under acetaldehyde concentration profile with time, Expts 8 and 9 were better than Expts 4,5 and 6. Up to this point, one can see how important oxygen is to this enzymatic reaction. From the comparison between Expt 8 and Expt 6 , it seems reasonable to overcome 'the oxygen limitation by reducing biomass concentration and avoid breaking cell structure by replacing pure oxygen by air. Of course, agitation is also important to offer better contact between alcohol oxidase and the ethanol substrate. Several investigators $[11,16,19,23,24]$ have shown that the optimum $\mathrm{pH}$ for alcohol oxidase ranged from 7.0-8.0. This was consistent with results of Expts 7 to 9 even though 7.5 is more accurate in this study. Another experiment run at $\mathrm{pH} 8.0$ was abandoned in the 5 th hour because of electrical shutdown. The initial production rate of acetaldehyde was worse than Expt 9. Careful examination 


\begin{tabular}{cccccccc} 
Expt & pH & $\begin{array}{c}\text { Temp } \\
(\circ \mathrm{C})\end{array}$ & $\begin{array}{c}\text { Air rate } \\
(1 / \mathrm{min})\end{array}$ & $\begin{array}{c}\text { Stirrer } \\
(\mathrm{rpm})\end{array}$ & $\begin{array}{c}\mathrm{DCW} \\
(\mathrm{g} / \mathrm{L})\end{array}$ & $\begin{array}{c}\text { Volume } \\
(\mathrm{ml})\end{array}$ & $\begin{array}{c}\text { Ethanol } \\
(\mathrm{g} / \mathrm{L})\end{array}$ \\
\hline 7 & $7.05-7.32$ & 30 & 2.0 & 200 & 9.9 & 2000 & 80 \\
8 & $7.16-7.24$ & 30 & $2.0-4.0$ & 200 & 9.9 & 2000 & 80 \\
9 & $7.45-7.55$ & 30 & $2.0-3.5$ & 200 & 9.9 & 2000 & 80 \\
\hline
\end{tabular}

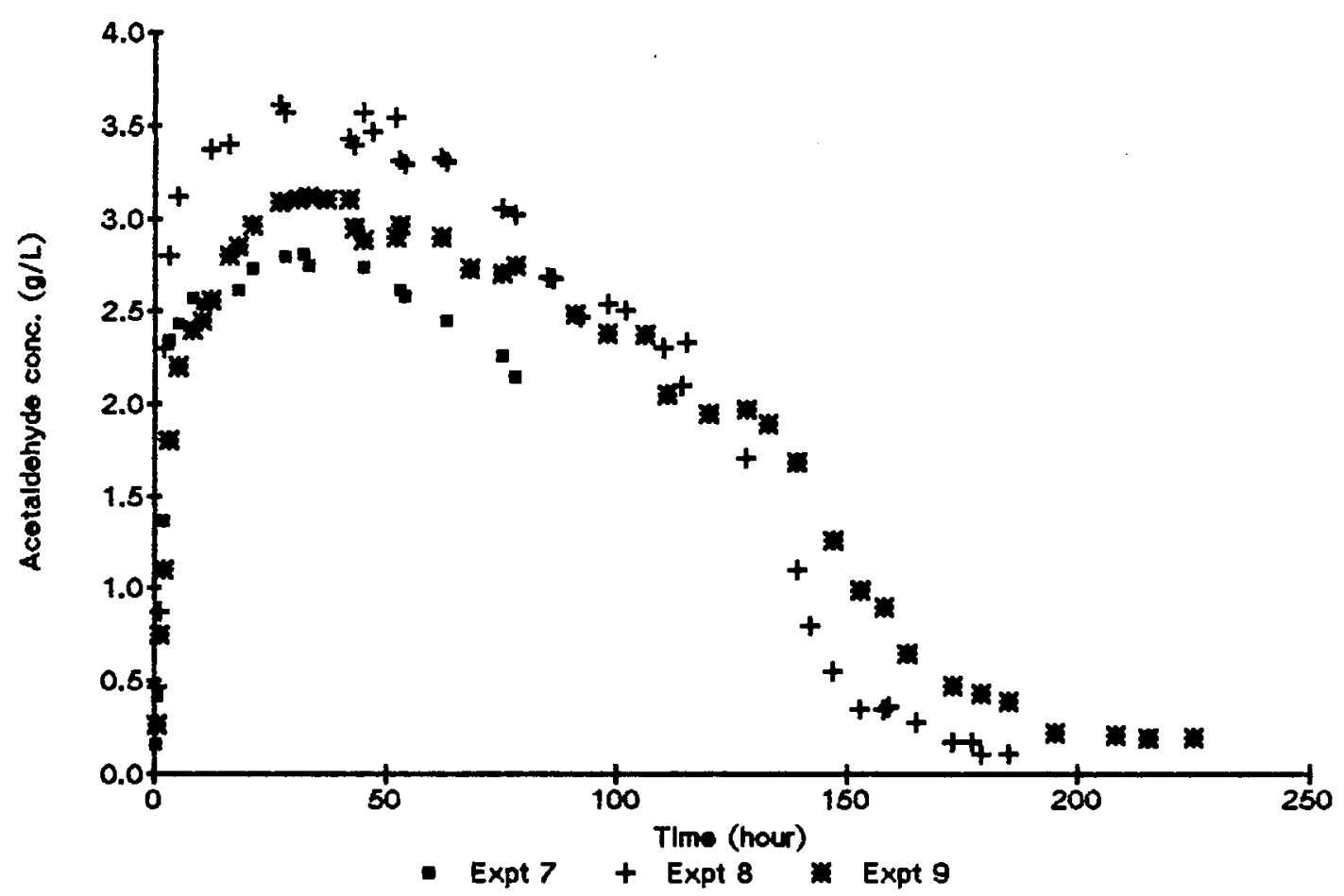

Figure 11. Acetaldehyde concentration profile in fermentor for Expts 7,8 and 9 . The biomass concentration was $9 \%$ cell broth (average $\mathrm{DCW}=9.9$ $g / L)$. 
of the results from Expts 8 and 9 reveals that Expt 8 has higher acetaldehyde concentration in the reaction medium but Expt 9 has longer reaction time. Both experiments yield almost the same overall acetaldehyde production rate. In order to have a better understanding of the effect of oxygen on the enzyme, Expts 10 to 13 tested different combinations of air and pure oxygen (Fig 12). Some expected results were observed: (1) pure air gave longer reaction time but a lower initial acetaldehyde production rate, (2) a higher oxygen ratio yielded a higher initial acetaldehyde production rate but had a shorter reaction time, and (3) Expt 13 with a doubled total gas flow rate of Expt 12 showed a higher initial rate but very short reaction time. This might be due to cell damage by higher oxygen flow rate.

The effect of initial ethanol concentration on acetaldehyde reaction was investigated again in Expts 14 to 16 (Fig 13). The results showed the same tendency as those in the first stage investigations. However, this time, the differences were not as sharp. Substrate concentration at $80 \mathrm{~g} / \mathrm{L}$ still yielded the best acetaldehyde production. The results of all experiments are described in Appendix $C$. 


\begin{tabular}{ccccccccc}
\multicolumn{10}{c}{ Operating Conditions } \\
Expt & pH & $\begin{array}{c}\text { Temp } \\
\left({ }^{\circ} \mathrm{C}\right)\end{array}$ & $\begin{array}{c}\text { Air rate } \\
(\mathrm{I} / \mathrm{min})\end{array}$ & $\begin{array}{c}\text { O2 rate } \\
(\mathrm{I} / \mathrm{min})\end{array}$ & $\begin{array}{c}\text { Stirrer } \\
(\mathrm{rpm})\end{array}$ & $\begin{array}{c}\mathrm{DCW} \\
(\mathrm{g} / \mathrm{L})\end{array}$ & $\begin{array}{c}\text { Volume } \\
(\mathrm{ml})\end{array}$ & $\begin{array}{c}\text { Ethanol } \\
(\mathrm{g} / \mathrm{L})\end{array}$ \\
\hline 10 & 7.5 & 30 & 2.0 & 0.0 & 200 & 9.9 & 2000 & 80 \\
11 & 7.5 & 30 & 1.0 & 1.0 & 200 & 9.9 & 2000 & 80 \\
12 & 7.5 & 30 & 1.5 & 0.5 & 200 & 9.9 & 2000 & 80 \\
13 & 7.5 & 30 & 3.0 & 1.0 & 200 & 9.9 & 2000 & 80 \\
\hline
\end{tabular}

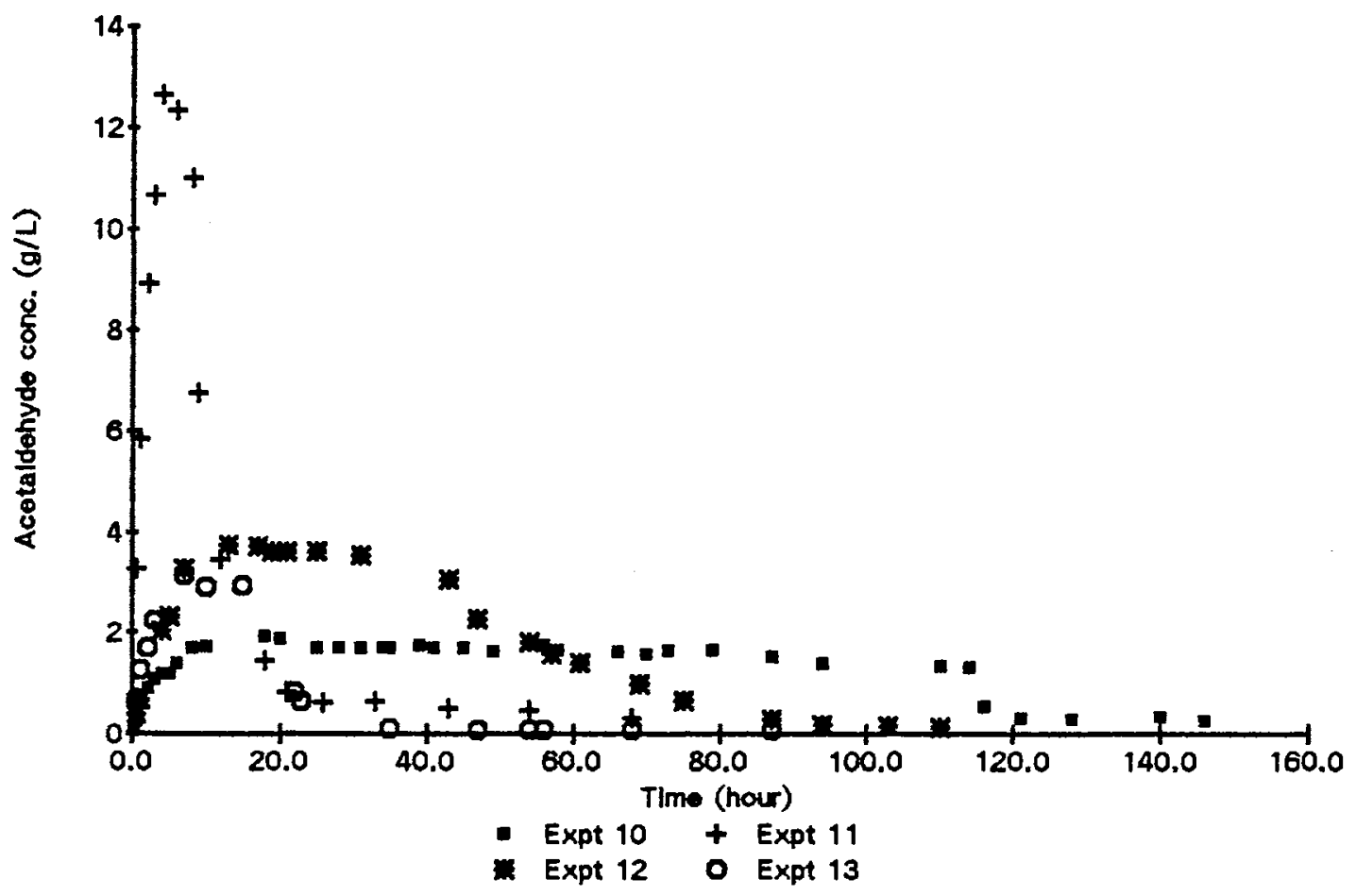

Figure 12. Acetaldehyde concentration profile in fermentor with different ratios of air to oxygen. 


\begin{tabular}{cccccccc} 
Expt & $\mathrm{pH}$ & $\begin{array}{c}\text { Temp } \\
\left({ }^{\circ} \mathrm{C}\right)\end{array}$ & $\begin{array}{c}\text { Air rate } \\
(\mathrm{l} / \mathrm{min})\end{array}$ & $\begin{array}{c}\text { Stirrer } \\
(\mathrm{rpm})\end{array}$ & $\begin{array}{c}\text { DCW } \\
(\mathrm{g} / \mathrm{L})\end{array}$ & $\begin{array}{c}\text { Volume } \\
(\mathrm{ml})\end{array}$ & $\begin{array}{c}\text { Ethanol } \\
(\mathrm{g} / \mathrm{L})\end{array}$ \\
\hline 14 & 7.5 & 30 & 2.0 & 200 & 9.9 & 2000 & 80 \\
15 & 7.5 & 30 & 2.0 & 200 & 9.9 & 2000 & 40 \\
16 & 7.5 & 30 & 2.0 & 200 & 9.9 & 2000 & 120 \\
\hline
\end{tabular}

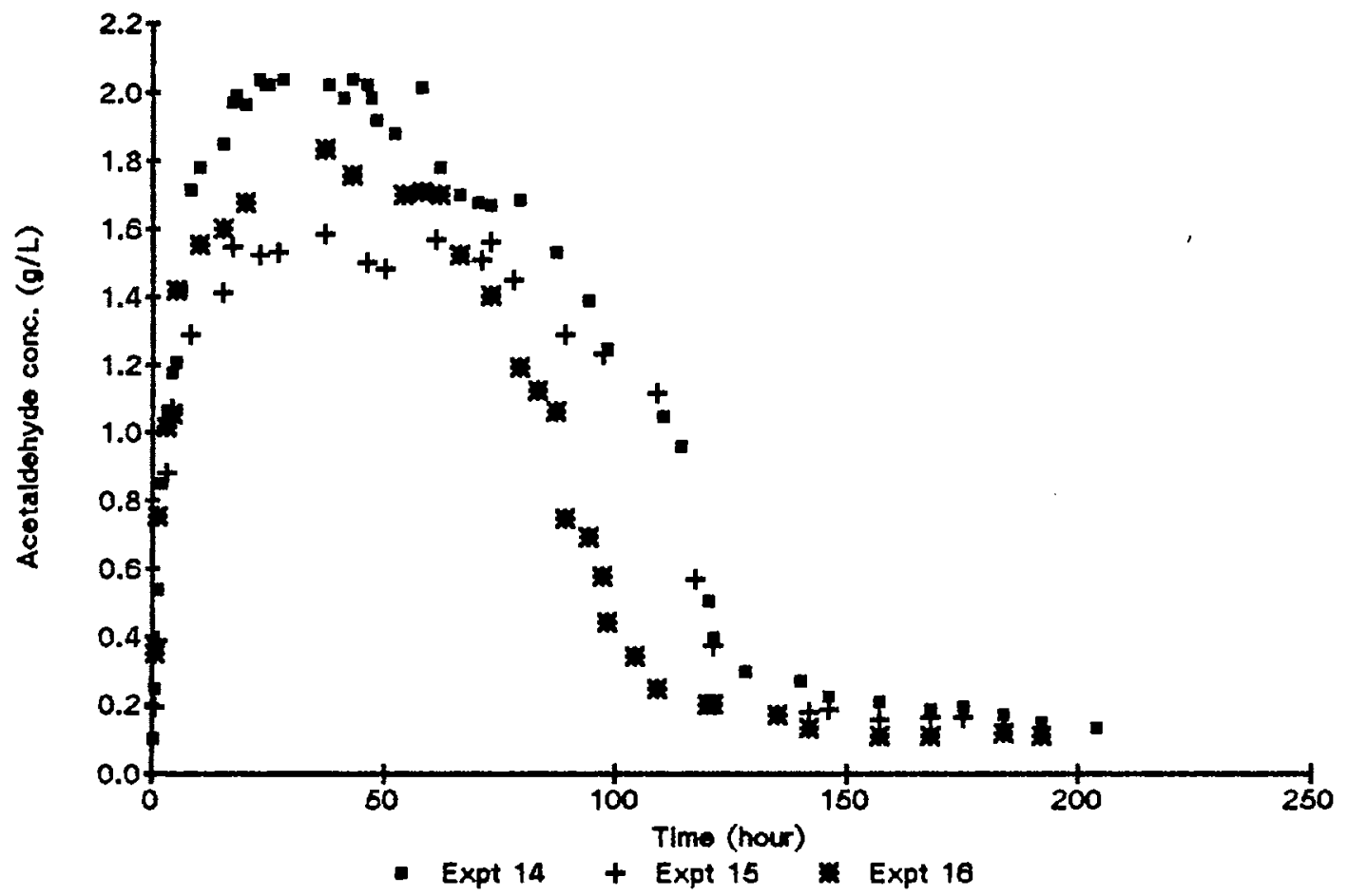

Figure 13. Acetaldehyde concentration profile in fermentor under different substrate concentrations. 


\section{CHAPTER V}

\section{MATHEMATICAL MODEL DEVELOPMENT}

Description of Modeled System

The system configuration is shown in Fig 14. This is basically an unsteady state, enzymatic CSTR operated in semi-batch mode. That is, the substrate, ethanol, is fed into the reactor to restore the original concentration whenever it becomes lower than $90 \%$ of its initial value. The feeding pattern and hypothetical product profile are shown in Fig 15 .

\section{Conditions and Assumptions}

In order to develop a mathematical model to simulate this complex enzymatic system, assumptions are necessary. a. Isothermal at $30^{\circ} \mathrm{C}$, isobaric at 1 atm.

b. Inlet gas is completely dried.

c. Perfect mixing in both liquid and gas phases.

d. Homogeneous liquid phase.

e. Equilibrium is achieved between the gas/vapor mixture and the liquid.

f. Gas/vapor mixture behaves like an ideal gas.

g. The dissolved gas concentration in the liquid remains constant. 


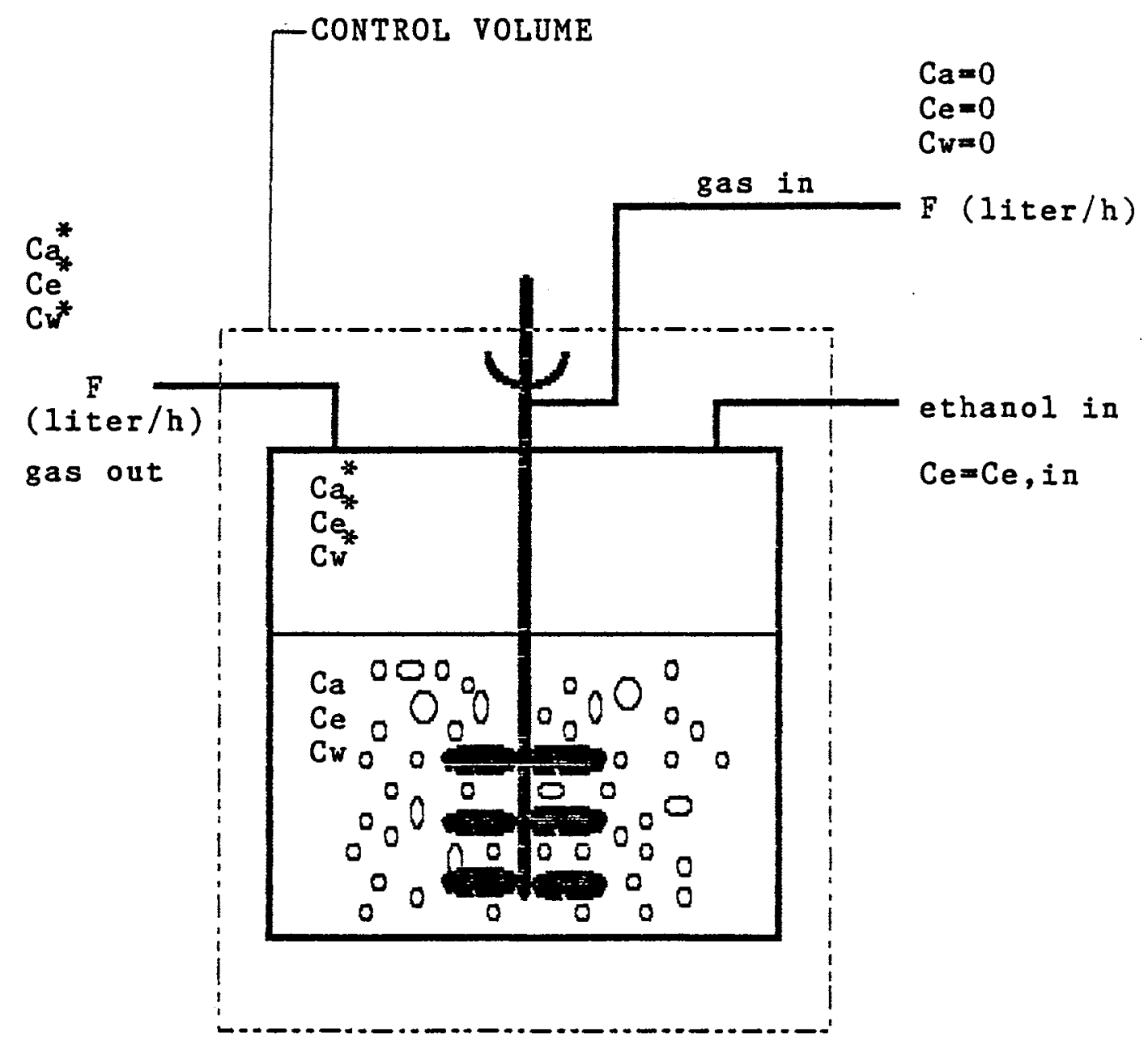

$$
\mathrm{C} 2 \mathrm{H} 5 \mathrm{OH}+\frac{1}{2} \mathrm{O} 2 \stackrel{\text { enzymes }}{\longrightarrow} \mathrm{CH} 3 \mathrm{CHO}+\mathrm{H} 2 \mathrm{O}
$$

Figure 14. The system configuration for acetaldehyde bioreactor. 

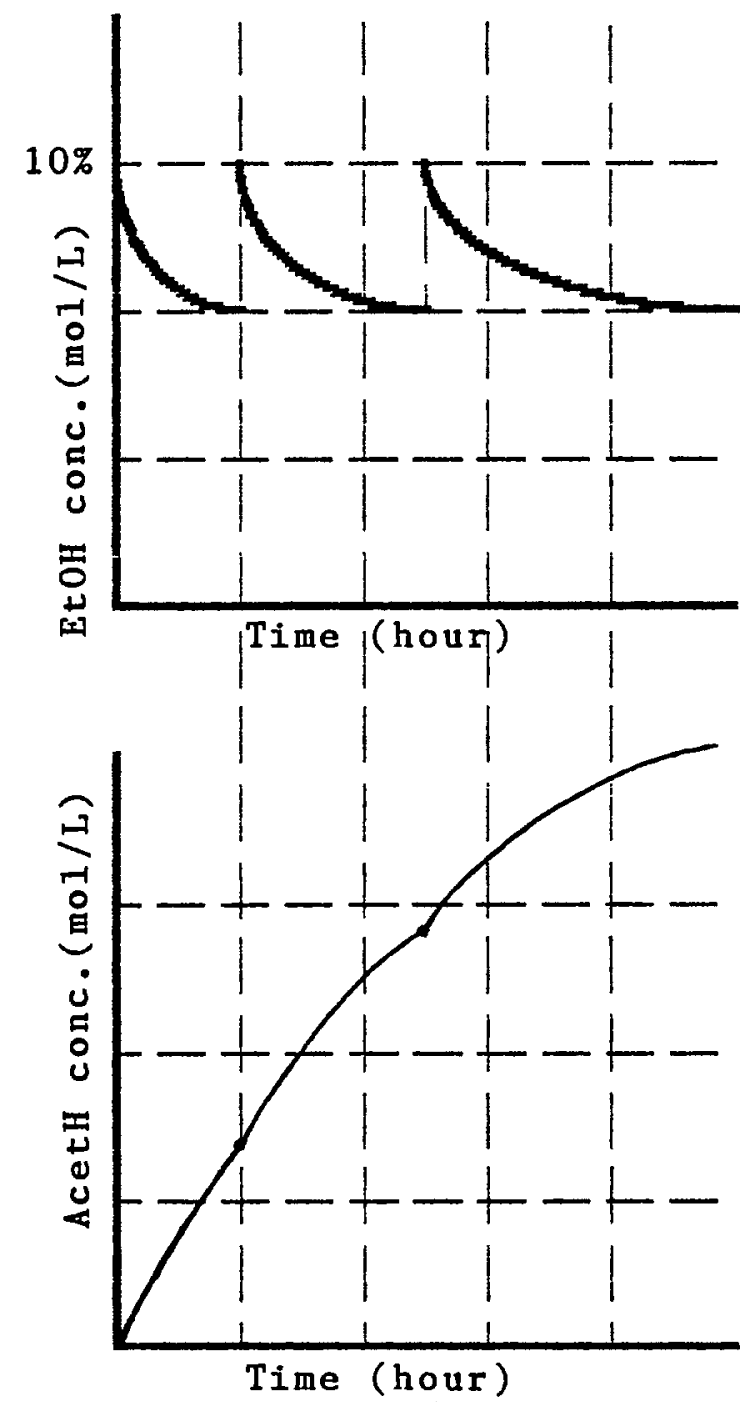

Figure 15. The feed pattern of ethanol and possible acetaldehyde profile. 
h. No product hold-up in the cells.

Notice that all the assumptions above are limited to this model only. Assumption (e) is generally a good

approximation in the earlier stage of liquid phase enzymatic reactions. However, as the cell wall begins to break and protein leaks out (near the end of reaction), this assumption is no longer true. Concerning assumption (i), Murray[16] reported there is about $10 \%$ acetaldehyde hold-up in whole cells. For the moment, this assumption simplifies the system.

Mathematical Expression

Material balance for acetaldehyde in the control volume, shown in Fig 14 , is:

$$
\begin{aligned}
& {\left[\begin{array}{l}
\text { rate of } \\
\text { acetaldehyde } \\
\text { accumulation }
\end{array}\right]=\left[\begin{array}{l}
\text { rate of } \\
\text { acetaldehyde } \\
\text { in }
\end{array}\right]+\left[\begin{array}{l}
\text { rate of } \\
\text { acetaldehyde } \\
\text { generation }
\end{array}\right]} \\
& \frac{\left(V_{1} C_{a}+V_{\mathbf{g}_{a}}\right)}{d t}=F C a_{a}, \text { in }+R_{a} V_{1}-F C_{a} *
\end{aligned}
$$

with initial condition $C_{a}=C_{a} i=0$. where,

V1 : liquid phase volume (liter).

$V_{g}$ : gas phase volume (liter).

$V_{0}$ : reactor total volume $\left(=V_{g}+V_{1}\right)$.

Ca : acetaldehyde conc. in liquid phase (mol/L). 
Cai : initial acetaldehyde conc. (mol/L).

$\mathrm{Ca}^{*}$ : acetaldehyde conc. in gas phase (mol/L).

Ca, in : input acetaldehyde conc. $(\mathrm{mol} / \mathrm{L})$. Because there is no input of acetaldehyde in this system, $\mathrm{Ca}_{\mathrm{a}}$ in $=0$.

F : volumetric gas flow rate (liter/h)

$R_{a}$ : rate equation $(\mathrm{mol} / \mathrm{L} / \mathrm{h})$.

$t$ : time (hour)

Expand the first term on the left, substitute $V_{g}=V_{o}-V_{1}$, $\frac{d V_{g}}{d t}=-\frac{d V_{1}}{d t}$, and rearrange, eq (1) becomes $V_{1} \frac{d C_{a}}{d t}=R_{a} V_{1}-\left[F C_{a} *+V_{B} \frac{d_{a} *}{d t}+\left(C_{a}-C_{a} *\right) \frac{d V_{1}}{d t}\right]$

Define,

$$
-\mathrm{V}_{1}\left[\frac{\mathrm{dC} a}{\mathrm{dt}}\right]_{\text {strp }}=\mathrm{FC}_{\mathbf{a}} *+\mathrm{V}_{\mathrm{g}} \frac{\mathrm{dC}^{*}}{\mathrm{dt}}+\left(\mathrm{C}_{\mathbf{a}}-\mathrm{Ca}_{\mathbf{a}} *\right) \frac{\mathrm{dV_{1 }}}{\mathrm{dt}}
$$

Then, eq (2) can be expressed as

$$
\frac{\mathrm{dC} \mathbf{a}}{\mathrm{dt}}=\mathrm{R}_{\mathbf{a}}+\left[\frac{\mathrm{dC} \mathbf{a}}{\mathrm{dt}}\right]_{\mathrm{strp}}
$$

At the same way, material balance for ethanol in the control volume (Fig 14) is:

$$
\frac{d C_{e}}{d t}=-R_{a}+\left[\frac{d C_{e}}{d t}\right]_{s t r p}
$$

with the initial and boundary conditions as

$$
\begin{array}{lll}
\text { I.C. } & \mathrm{Ce}=\mathrm{Ce} i \text { at } \mathrm{t}<0 \\
\text { B.C. } & \mathrm{Ce}=\mathrm{Ce} i \text { when } \mathrm{Ce}<=0.9 \cdot \mathrm{Ce} i
\end{array}
$$


The boundary condition is based on the assumption that whenever the ethanol concentration is below $90 \%$ of its initial value, it is refilled quickly to the original concentration.

where,

$-V_{1}\left[\frac{d C_{e}}{d t}\right]_{s t r p}=F C_{e}^{*}+V_{g} \frac{d C_{e}^{*}}{d t}+\left(C_{e}-C_{e}^{*}\right) \frac{d V_{1}}{d t}$

Ce : ethanol conc, in liquid phase (mol/L).

Cei : initial ethanol conc. (mol/L).

In order to solve eq (4) and eq (5) simultaneously, the following information must be known:

$R_{a}$ : rate equation.

$\mathrm{Ca}_{\mathrm{a}}, \mathrm{Ca}^{*}$ : equilibrium concentrations of acetaldehyde in the liquid and vapor phases.

$\mathrm{Ce}_{e}, \mathrm{Ce}^{*}$ : equilibrium concentrations of ethanol in the liquid and vapor phases.

$\left[\frac{d C_{a}}{d t}\right]_{\text {strp, }}\left[\frac{d C e}{d t}\right]_{\text {strp }}:$ the stripping rate $(\operatorname{mol} / \mathrm{L} / \mathrm{h})$ of

A. Equilibrium relation

For multicomponent vapor/liquid equilibrium, $f_{i} g=y_{i} \phi_{i} \pi=\epsilon_{i x_{i}} f_{i}=f_{i} \quad(i=1,2, \ldots N)$

at low pressure, vapor phases approximates ideal gas, eq (7) becomes

$$
E_{i}=\frac{y_{i} \pi}{x_{i} P_{i} \text { sat }}
$$

where,

$f_{i} s$ : fugacity of component $i$ in vapor phase. 
$f_{i} l$ : fugacity of component $i$ in liquid phase.

$y_{1}$ : mole fraction of component i in vapor phase.

$\pi$ : total pressure.

$E_{i}$ : activity coefficient of component $i$.

$x_{i}$ : mole fraction of component $i$ in liquid phase.

$p_{i}$ sat : saturated vapor pressure of pure component $i$.

The stoichimetric relation between acetaldehyde and ethanol in this reaction is:

\begin{tabular}{lccc}
$\mathrm{C}_{2} \mathrm{H}_{5} \mathrm{OH}+\frac{1}{2} \mathrm{O}_{2} \stackrel{\text { enzyme }}{\longrightarrow}$ & $\mathrm{CH}_{3} \mathrm{CHO}+\mathrm{H}_{2} \mathrm{O}$ \\
$\mathrm{Ne}_{\mathrm{i}}$ & $\mathrm{N}_{0} \mathrm{i}$ & 0 & $\mathrm{~N}_{w i}$ \\
$-\mathrm{n}$ & $-\mathrm{n}$ & $+\mathrm{n}$ & $+\mathrm{n}$ \\
\hline$\left(\mathrm{N}_{\mathrm{e} i}-\mathrm{n}\right)$ & $\left(\mathrm{N}_{0} \mathrm{i}-\mathrm{n}\right)$ & $(\mathrm{n})\left(\mathrm{N}_{\mathrm{w}}+\mathrm{n}\right)$
\end{tabular}

total moles $=\left(N_{e}-n\right)+\left(N_{i}-n\right)+n+\left(N_{w i}+n\right)$

$=\mathrm{Ne}_{1}+\mathrm{N}_{W i}+\mathrm{n}$

Notice that Noi-n, moles of dissolved oxygen, is

negligible when compared to $n$ or $N_{e} 1$ or $N_{w i}$ (i.e. Noi-n $<n$ or $\mathrm{Ne}_{i}$ or $\mathrm{N}_{\mathrm{w}}$ ).

where,

Ne1 : initial moles of ethanol.

No1 : initial moles of dissolved oxygen.

$N_{w 1}$ : initial moles of water.

n : moles consumed (produced) in reaction.

Thus, the mole fraction of each component is

$$
\begin{aligned}
& X_{a}=\frac{n}{N_{e}+N_{w i}+n}=\frac{C_{a}}{C_{e} 1+C_{w i}+C_{a}} \\
& X_{e}=\frac{N_{e}-n}{N_{e} 1+N_{w 1}+n}=\frac{C_{e}-C_{a}}{C_{e} 1+C_{w 1}+C_{a}}
\end{aligned}
$$




$$
\mathrm{X}_{\mathrm{w}}=1-\mathrm{X}_{\mathrm{a}}-\mathrm{X}_{\mathbf{e}}
$$

Since $C_{a} \ll C_{e} 1+C_{w 1}$, let $C_{e} i+C_{w 1}=C_{o}$, eq (9), (10) and (11) reduce to

$$
\begin{aligned}
& X_{a}=\frac{C_{a}}{C_{0}} \\
& X_{e}=\frac{C_{e} i-C_{a}}{C_{0}} \\
& X_{w}=1-X_{a}-X_{e}
\end{aligned}
$$

Substitute eq (12) and eq (13) into eq (8), one gets

$$
\begin{aligned}
& C_{a}^{*}=\frac{y_{a} \pi}{R T}=\frac{\epsilon_{a} P_{a} s a t}{R T} \frac{C_{a}}{C_{0}} \\
& C_{e}^{*}=\frac{y_{e} \pi}{R T}=\frac{\epsilon_{e} P_{a} s a t}{R T} \frac{C_{e}}{C_{o}}
\end{aligned}
$$

where,

(1) Pisat can be obtained by Antonine vapor-pressureequation [28].

Acetaldehyde $: \ln \left(\mathrm{Pa}_{\mathrm{a}} \mathrm{at}\right)=16.2481-2465.15 /(\mathrm{T}-37.15)$

Ethanol $\quad: \ln \left(\mathrm{Pe}_{\mathrm{sat}}\right)=18.9119-3803.98 /(\mathrm{T}-41.68)$

Water $\quad: \ln \left(\mathrm{P}_{\mathrm{w}} \mathrm{sat}\right)=18.3036-3816.44 /(\mathrm{T}-46.13)$

at 1 atm and $30^{\circ} \mathrm{C}$,

$\mathrm{Pa}_{\mathrm{a}} \mathrm{sat}=1075.6 \mathrm{mmHg}=1.4153 \mathrm{~atm}$

$\mathrm{Pe}_{\mathrm{sat}}=78.5 \mathrm{mmHg}=0.1033 \mathrm{~atm}$

$P_{w}$ at $=31.7 \mathrm{mmHg}=0.0417 \mathrm{~atm}$

(2) $\epsilon_{i}$ can be predicted by using UNIFAC method, a significant development in the molecular thermodynamics of liquid behavior based on the concept of local composition [29-31]. The UNIFAC method calculates the 
activity coefficients from contributions of the various groups making up the moleculars of a solution. A computer program is attached in Appendix $D$ to predict the activity coefficient for each component.

B. Simplification

For the system concerned, Co $\left(=C_{e} i+C_{w i}\right)$ is 50.87 and 52.61 mole/L for ethanol concentration at $15 \%$ and $5 \%$ (water at $75 \%$ and $85 \%), \epsilon_{a}$ is from 4.203 to 4.210 , $\epsilon_{e}$ is from 3.746 to 3.755 , and $F$ is 1201 iter/hr. Substitute all these values into eq (15) and eq (16), it is obviously that $\mathrm{Ca}^{*} \ll \mathrm{C}_{\mathrm{a}}$ and $\mathrm{Ce}^{*} \ll \mathrm{Ce}_{\mathrm{e}}$. Thus eq (3) and eq (6) can be simplified as

$$
\begin{aligned}
& {\left[\begin{array}{l}
d C_{a} \\
--- \\
d t
\end{array}\right]_{s t r p}=\underset{V_{1}}{---}\left[F_{a} *+C_{a} \frac{d V_{1}}{d t}\right]} \\
& =\left[\begin{array}{cc}
F \epsilon_{a} P_{a} s a t & d V_{1} \\
\hdashline \text { RTCo }_{0} & \text { dt }
\end{array}\right] \frac{C_{a}}{--} \\
& =\left[\begin{array}{ll}
(120)\left(\epsilon_{a}\right)(1.4513) \\
\hdashline(0.082)(303.2) \mathrm{Co}_{0} & \mathrm{dV} \mathrm{d}_{1}
\end{array}\right] \begin{array}{c}
\mathrm{Ca}_{\mathrm{a}} \\
\mathrm{dt}
\end{array} \\
& {\left[\begin{array}{l}
\mathrm{dC}_{\mathrm{a}} \\
\hdashline-- \\
\mathrm{dt}
\end{array}\right]=\left[(6.8310)\left(-\frac{\epsilon_{a}}{\mathrm{Co}_{0}}\right)+\frac{\mathrm{dV}_{\mathbf{1}}}{\mathrm{dt}}\right]-\frac{\mathrm{Ca}_{\mathbf{a}}}{\mathrm{V}_{\mathbf{l}}}}
\end{aligned}
$$

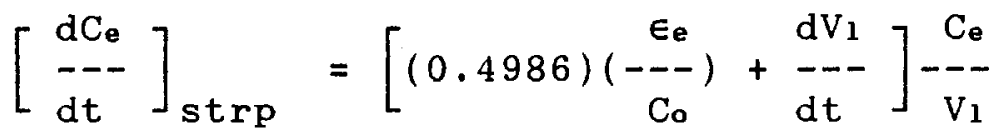

C. Determination of Acetaldehyde and Water Stripping Rate

The stripping effect of acetaldehyde or ethanol can be obtained either from theoretical derivation, eq (17) and 
eq (18), or from experimental correlation.

\section{(1) Theoretical Derivation}

For the experiments we have run and the concentrations of all components concerned, take $\mathrm{C}_{0}=52 \mathrm{~mole} / \mathrm{L}, \epsilon_{\mathrm{a}}=4.2$, $\epsilon_{e}=3.75$ and $\mathrm{dV}_{1} / \mathrm{dt}=0.01, \mathrm{~F}=120 \mathrm{l} / \mathrm{hr}$. Substitute $\epsilon_{\mathrm{a}}, \epsilon_{\mathrm{e}}$, $d V_{1} / d t$ and $F$ into eq (17) and (18), the stripping rates for acetaldehyde and water are

$$
\begin{aligned}
& {\left[\frac{d C_{a}}{d t}\right]_{s t r p}=-0.2812 \mathrm{Ca} \quad \operatorname{mol} / \mathrm{L} / \mathrm{h}} \\
& {\left[\frac{d C_{e}}{d t}\right]_{\text {strp }}=-0.0230 \mathrm{Ce} \quad \mathrm{mol} / \mathrm{L} / \mathrm{h}}
\end{aligned}
$$

(2) Experimental correlation

In order to evaluate the effectiveness of eq (19) and eq (20), a similar experiment without reaction has been performed to express the acetaldehyde and ethanol concentrations as a function of time. The operation conditions are the same as Expt 14 except there are no cells in reactor. Fig 16 and 17 show the concentration profiles of acetaldehyde and ethanol as a function of time. By using nonlinear least square curve-fitting, they can be expressed as

$$
\begin{aligned}
& C_{a}=0.2860 \times e^{-0.29344} t(\operatorname{mole} / L) \\
& C_{e}=2.2583 \times e^{-0.02203} t(\mathrm{~mole} / L)
\end{aligned}
$$

or 


\section{AcetH/EtOH/Water Stripping System}

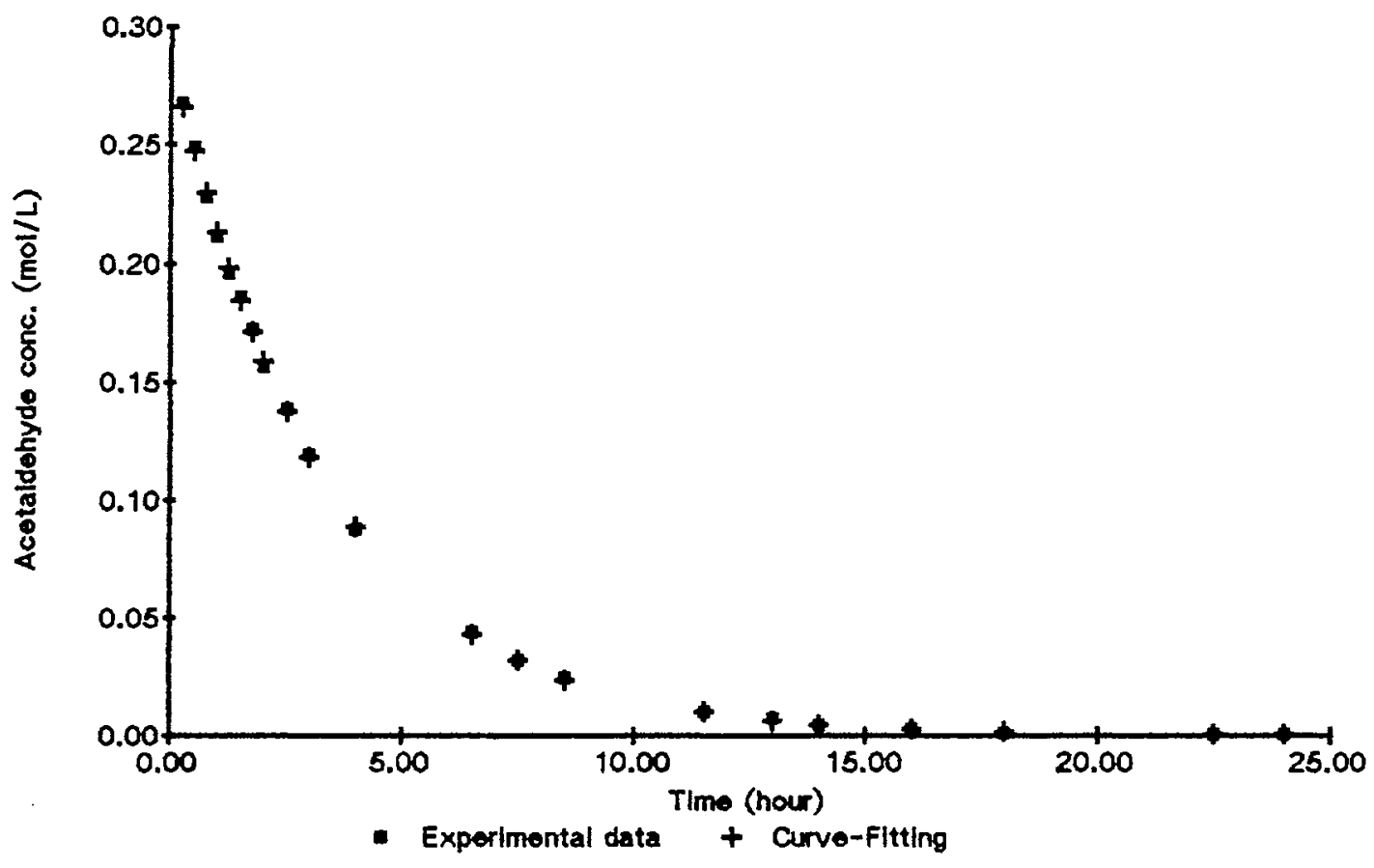

Figure 16. The acetaldehyde concentration in a no reaction stripping system. 


\section{AcetH/EtOH/Water Stripping System}

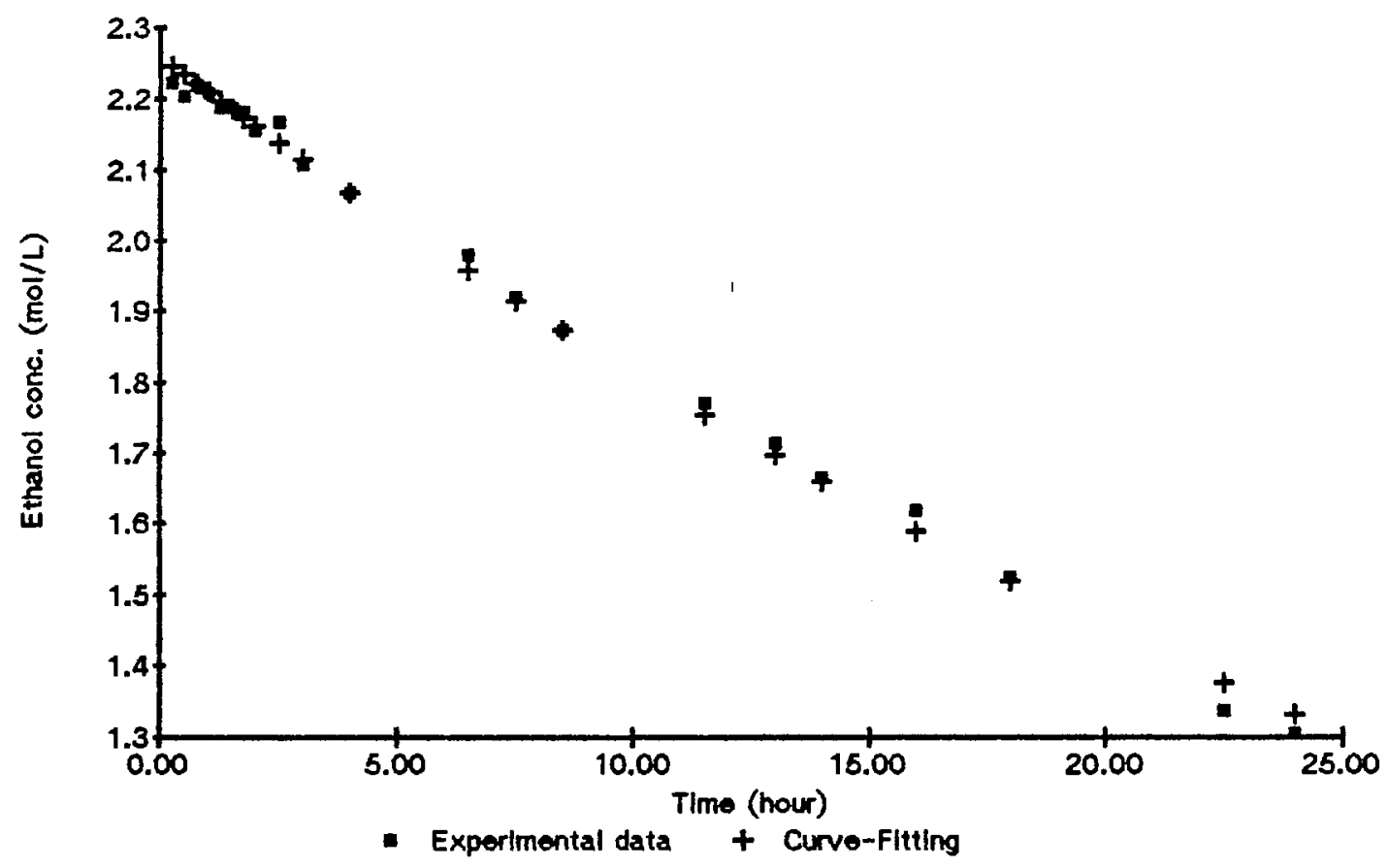

Figure 17. The ethanol concentration in a no reaction stripping system. 


$$
\begin{aligned}
& \frac{d C_{a}}{d t}=-0.2934 \mathrm{Ca}_{a} \\
& \frac{d C_{e}}{d t}=-0.0220 \mathrm{Ce}
\end{aligned}
$$

The deviations of eq (19) and (20) to eq (21) and (22) are $4.2 \%$ and $4.5 \%$, respectively. Thus, eq (4) and eq (5) can be rewritten as

$$
\begin{aligned}
& \frac{\mathrm{dC}_{a}}{\mathrm{dt}}=\mathrm{R}_{\mathbf{a}}-0.2934 \mathrm{Ca}_{\mathbf{a}} \\
& \frac{\mathrm{dC}_{\mathrm{e}}}{\mathrm{dt}}=-\mathrm{R}_{\mathrm{a}}-0.0220 \mathrm{C}_{\mathrm{e}}
\end{aligned}
$$

Notice that the values 0.2934 and 0.220 are function of flow rate, concentration, temperature, and liquid volume strippedout per hour by air. These values are constants for the case studied.

D. Rate Equation Evaluation

From the plot of maximum acetaldehyde concentration velocity vs. initial substrate concentration for Expts 14 , 15 and 16 , the maximum velocity occurs when initial ethanol concentration is about $10 \%(80 \mathrm{~g} / \mathrm{L})$. It means that the substrate inhibition begins to appear when ethanol concentration is greater than $10 \%$. Of course, product (acetaldehyde) inhibition is also observed even though it is not great (around $10 \%-15 \%$ as reported by Murray [16]). Thus, a simultaneous substrate and inhibition kinetic model [32-36] should be developed in order to account for these effects. 
The proposed model is

$$
R_{a}=\frac{V_{n} S}{K_{s}+S+S^{2} / K_{i}} \cdot \frac{\exp \left(-D_{i} C_{a}\right)}{(1-1 /(1+\exp (-A+B t))}
$$

where the rate constants are

$$
\begin{array}{rlr}
\mathrm{V}_{\mathbf{m}}=0.081 & \mathrm{~mol} / \mathrm{L} \\
\mathrm{K}_{\mathbf{s}}=3.06 & \mathrm{~mol} / \mathrm{L} \\
\mathrm{K}_{\mathbf{i}}=0.85 & \mathrm{~mol} / \mathrm{L} \\
\mathrm{D}_{\mathbf{1}}=5.854 & \mathrm{~L} / \mathrm{mol} \\
\mathrm{A}=-3.864 & \\
\mathrm{~B}=0.0275 & \mathrm{hr}-1
\end{array}
$$

Equations (23) and (24) are solved numerically by using a forward finite difference method, a computer program is attached in Appendix E. The comparisons of the proposed model and experimental data for Expts 14,15 and 16 are shown in Figs 18,19 and 20 respectively. The model departure with experimental data becomes large when the operating time is greater than 100 hours. This is due to a poor mathematical expression for the rapid enzyme deactivation. 


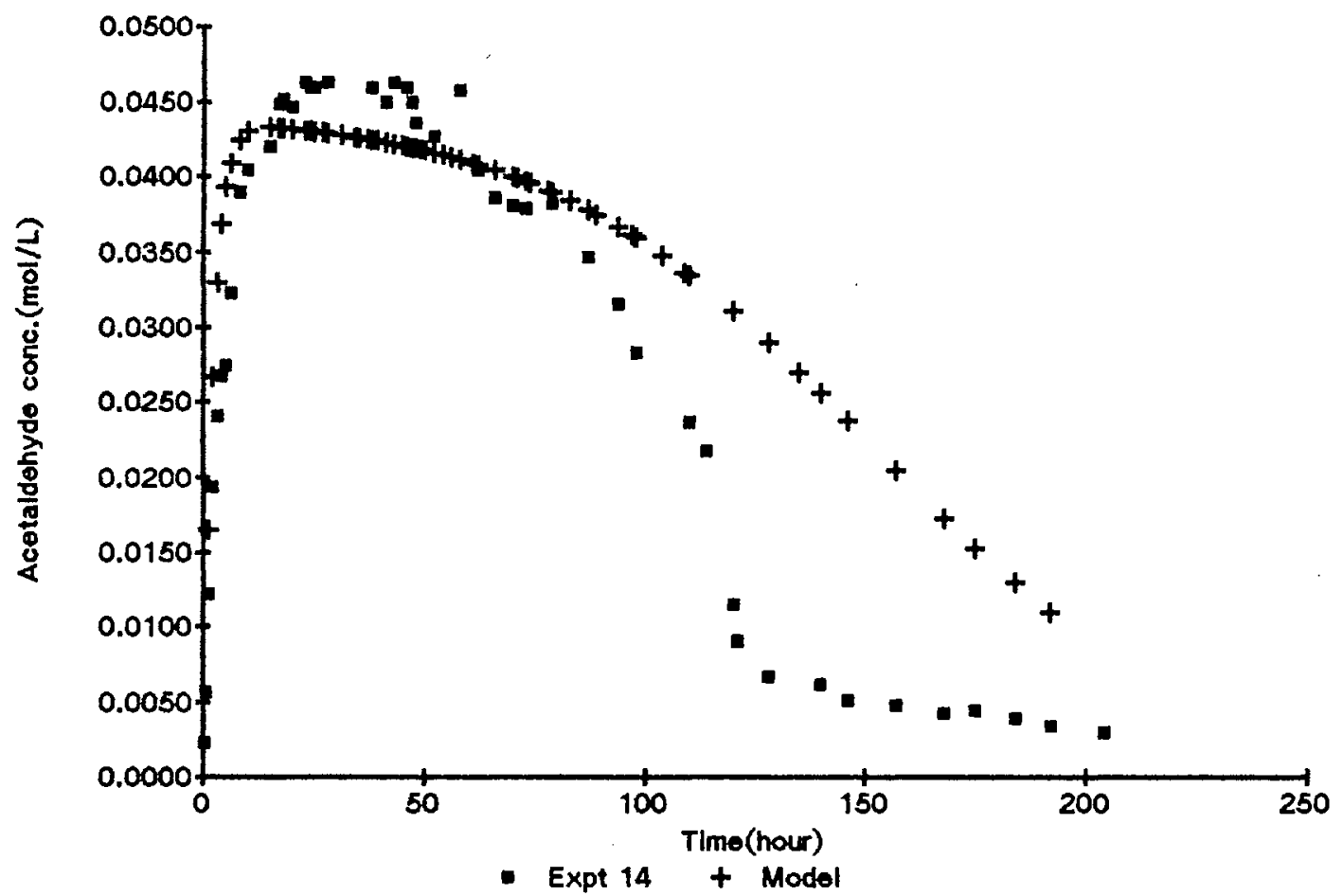

Figure 18. A fit to Expt 14 (10\% ethanol) by proposed model. 


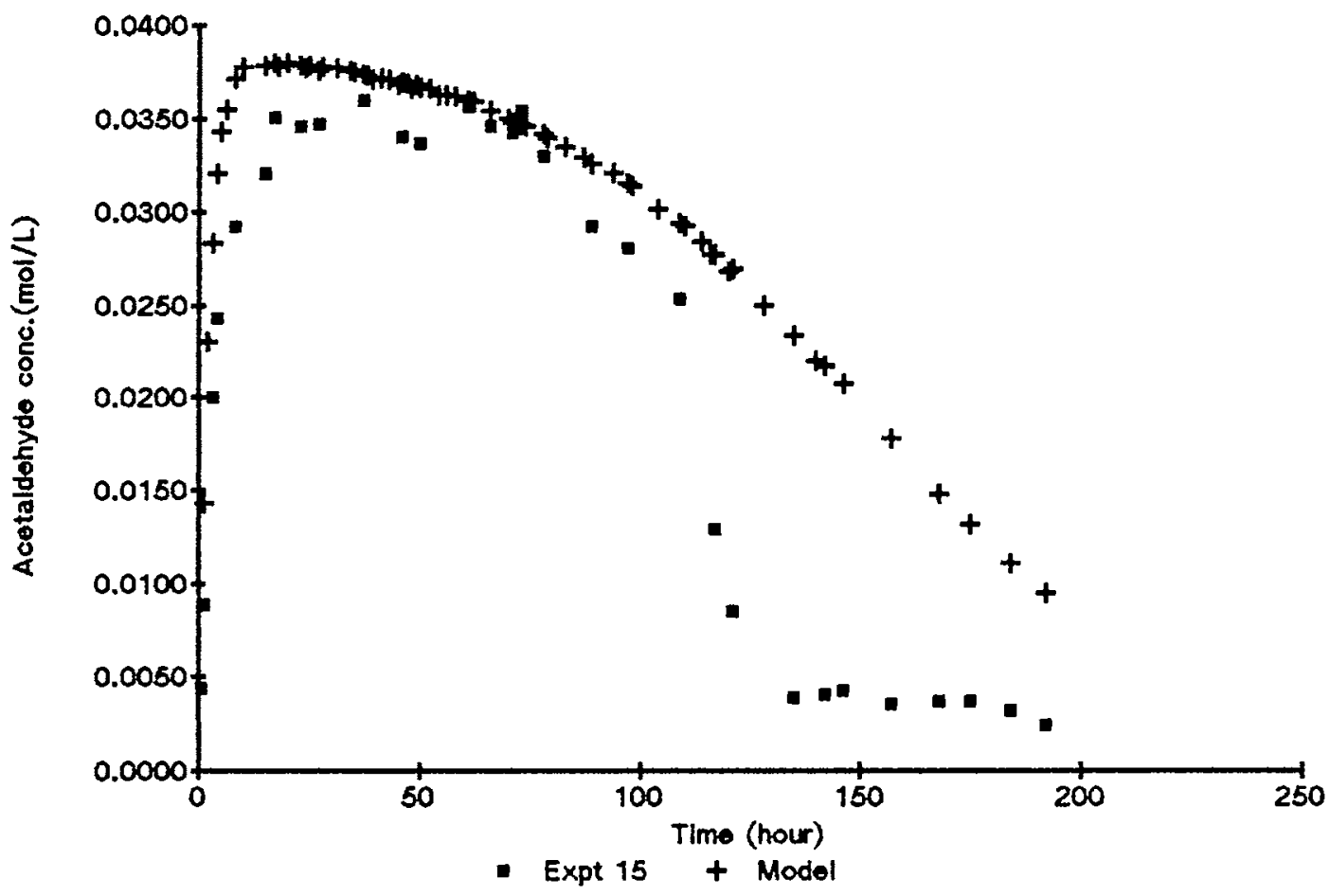

Figure 19. A fit to Expt 15 (5\% ethanol) by proposed model. 


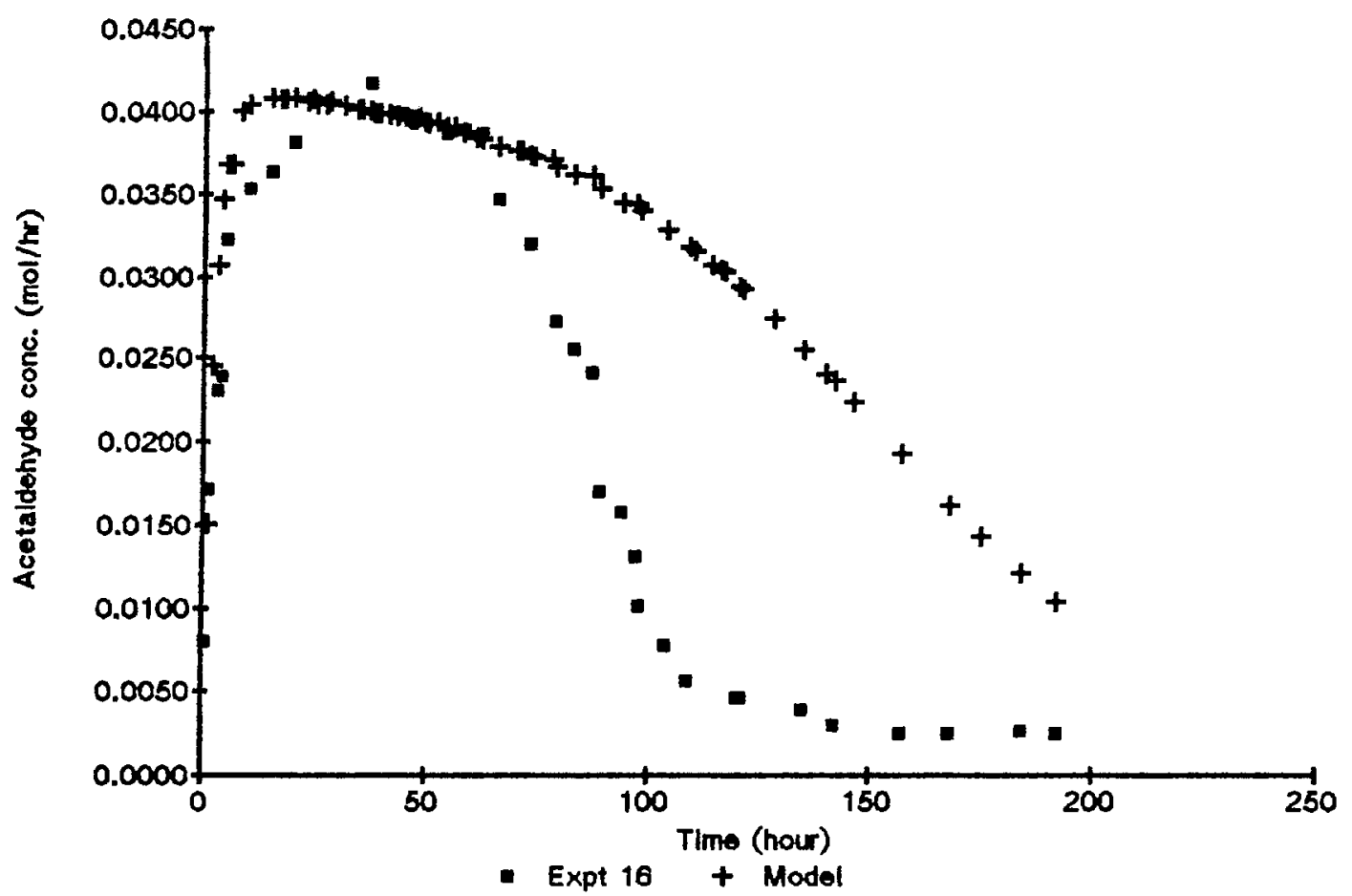

Figure 20. A fit to Expt 16 (15\% ethanol) by proposed model. 
CHAPTER VI

REACTOR DESIGN AND ECONOMIC EVALUATION

OF AN ACETALDEHYDE BIOPROCESS

\section{Reactor Design}

The model developed in CHAPTER $V$ is used to size the acetaldehyde bioreactor. Three cases are studied; (1) a batch reactor, (2) three batch reactors operated in sequence, and (3) a batch reactor with old cells withdrawn and new cells fed. The processes for each case is proposed and the economic evaluation for each one is also studied.

\section{Conditions and Assumptions}

1. The volumetric air flow rate (liter/min) is equal to the volume occupied by the broth.

2. The acetaldehyde recovery efficiency is $60 \%$.

3. The cell loss during reaction is negligible (about $1 \%$ ).

4. The operation time for each batch is 120 hours ( 5 days) in case (1) and 168 hours ( 7 days) for case (2). For case(3), the reactor is operated continuously for 300 days.

Case (1): a batch reactor designed to produce <a 75,000 gal/year, or <b> $125,000 \mathrm{gal} /$ year, or 


$$
\text { 〈c } 200,000 \mathrm{gal} / \mathrm{year} \text {. }
$$

From Chapter $V$, the acetaldehyde production rate is $\mathrm{FC}_{\mathrm{a}}$, where $\mathrm{Ca}_{\mathrm{a}}$, can be evaluated from eq (15).

$$
\mathrm{Ca}_{\mathrm{a}} * \frac{\mathrm{Ya}_{\mathrm{a}} \pi}{\mathrm{RT}}=\frac{\mathrm{EaPa}_{\mathrm{a}} \mathrm{at}}{\mathrm{RT}} \frac{\mathrm{Ca}_{\mathrm{a}}}{\mathrm{C}_{\mathrm{a}}}=0.004754 \cdot \mathrm{Ca}
$$

Thus, the overall acetaldehyde produced in one batch is equal to $($ time/batch $) \cdot(F) \cdot\left(0.004754 \cdot C_{a}\right)$. The units for $F$ and $C_{a}$ are liter/h and mol/L respectively. (a) 75,000 gal/yr: assume there are 50 batches per year, then it becomes $1,500 \mathrm{gal} / \mathrm{batch}(=100,690 \mathrm{~mol}$ AcetH/batch $)$.

$$
F \int\left(C_{a}^{*}\right) d t=100,690 /(0.6)
$$

the $\int\left(C_{a}^{*}\right) d t$ can be calculated by graphic method (Fig 21) and the results are listed below,

$$
\begin{array}{lll}
\text { first day: } & 4.48 \times 10-3 & \mathrm{~mol} \cdot \mathrm{h} / \mathrm{L} \\
\text { second day: } & 4.84 \times 10-3 & \mathrm{~mol} \cdot \mathrm{h} / \mathrm{L} \\
\text { third day: } & 4.64 \times 10-3 & \mathrm{~mol} \cdot \mathrm{h} / \mathrm{L} \\
\text { fourth day: } & 4.32 \times 10-3 & \mathrm{~mol} \cdot \mathrm{h} / \mathrm{L} \\
\text { fifth day: } & 3.84 \times 10-3 & \mathrm{~mol} \cdot \mathrm{h} / \mathrm{L}
\end{array}
$$

thus, for each batch

$$
\int\left(C_{a}^{*}\right) d t=0.02212 \mathrm{~mol} \cdot \mathrm{h} / \mathrm{L}
$$

substute eq (27) into eq (26), then

$$
F=7,586,649 \text { liters } / \mathrm{h}=126,444 \text { liters } / \mathrm{min}
$$

assume the broth volume is $2 / 3$ of the reactor volume, then

$$
\mathrm{V}=126,444 \cdot 3 / 2 \approx 189,700 \text { liters }
$$


Acetaldehyde conc. In gas phase

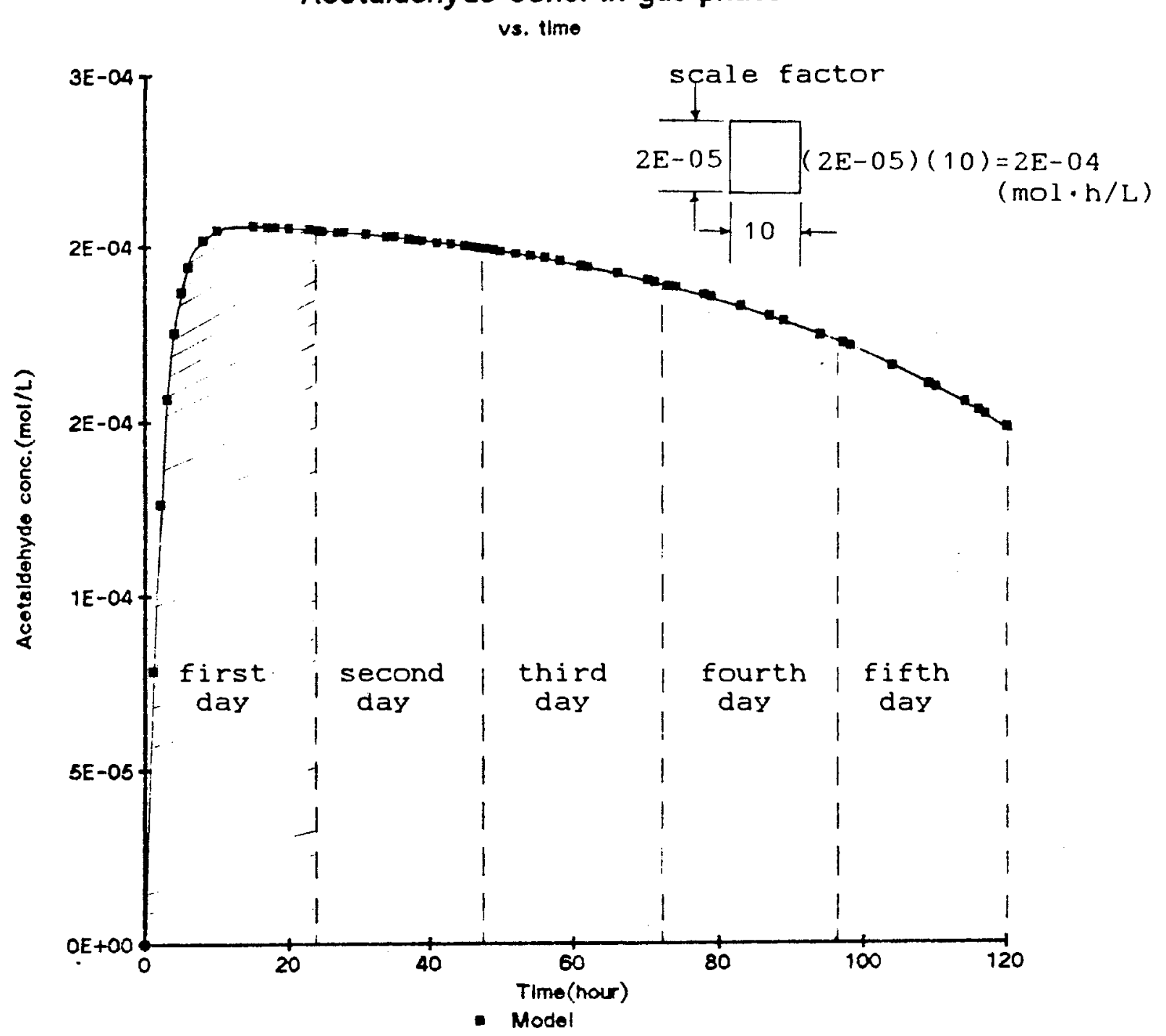

Figure 21. The graphic method for total acetaldehyde produced in one batch (case 1 ). 
<b> $125,000 \mathrm{gal} / \mathrm{yr}$

The derivation is the same as $\langle a\rangle$, this time the reactor volume,

$\mathrm{V} \approx 316,100$ Liters

<c $200,000 \mathrm{gal} / \mathrm{yr}$

The derivation is the same as $\langle a\rangle$, this time the reactor volume,

$\mathrm{V} \approx 505,800$ Liters

Case (2): three batch reactors are operated in sequence and 36 batches/yr for each reactor.

The operating algorithm is,

1 th batch: operated at day 1 , day 9 , day $17, \ldots \ldots$

2nd batch: operated at day 2 , day 10 , day $18, \ldots \ldots$

3rd batch: operated at day 3 , day 11 , day $19, \ldots \ldots$

that is, the overall operating time for each batch is 8 days ( 7 days operation plus 1 days shutdown for maintenance). Three-day spacing yields a better acetaldehyde production profile, and thus more economical downstream processing (Fig 23). In order to compare case (2) with case(1), the total batches per year for case (2) is thirty-six. That is there are $36 \cdot 7 \approx 250$ working days per year in case (2) as $50 \cdot 5=$ 250 working days per year in case(1).

The $\int\left(\mathrm{Ca}^{*}\right) \mathrm{dt}$ can be calculated by graphic method 
(Fig 22). The plot of $\int\left(\mathrm{Ca}^{*}\right) \mathrm{dt}$ vs. time (day) is shown in

Fig 23 and the daily acetaldehyde production of all three batches is tabulated in Table 8 .

For $75,000 \mathrm{gal} / \mathrm{yr}$, the reactor volume for each is 69,200 liters. For producing $125,000 \mathrm{gal} / \mathrm{yr}$ and 200,000 gal/yr, the volume are 115,300 liters and 184,400 liters for each batch reactor separately. The results show case (2) is a little worse than case (1). The reason is it is not economic to continue the operation in the 6 th and $7 \mathrm{th}$ days because of the low acetaldehyde production rate.

Case (3): a batch reactor with cell refreshed.

Since enzyme deactivation proceeds with respect to time, some old cells withdrawn and some new cells fed is necessary to keep enzyme activity high. The new cells introduced to the reactor begin at hour 60 and three cases of cell-input-rate are considered; $\langle a\rangle 0.5 \%$ initial

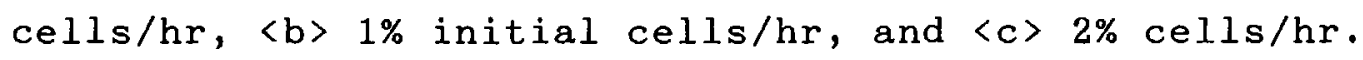

Since we assume perfect mixing (CSTR), a method must be developed for enzyme activity to account for the cells introduced in different time intervals. The simplest method is a normal distribution in statistics. That is,

$$
\text { Enzyme Activity }=\sum_{i} \operatorname{Cf}_{\mathbf{f}} \mathbf{t} \Phi_{i t}
$$
where,

Cfrit: the cell fraction of group $i(e . g .90 \%)$ at time $t$.

$\Phi_{i t}$ : the enzyme activity of cell group $i$ at time $t$. 
Acetaldehyde conc. In gas phase

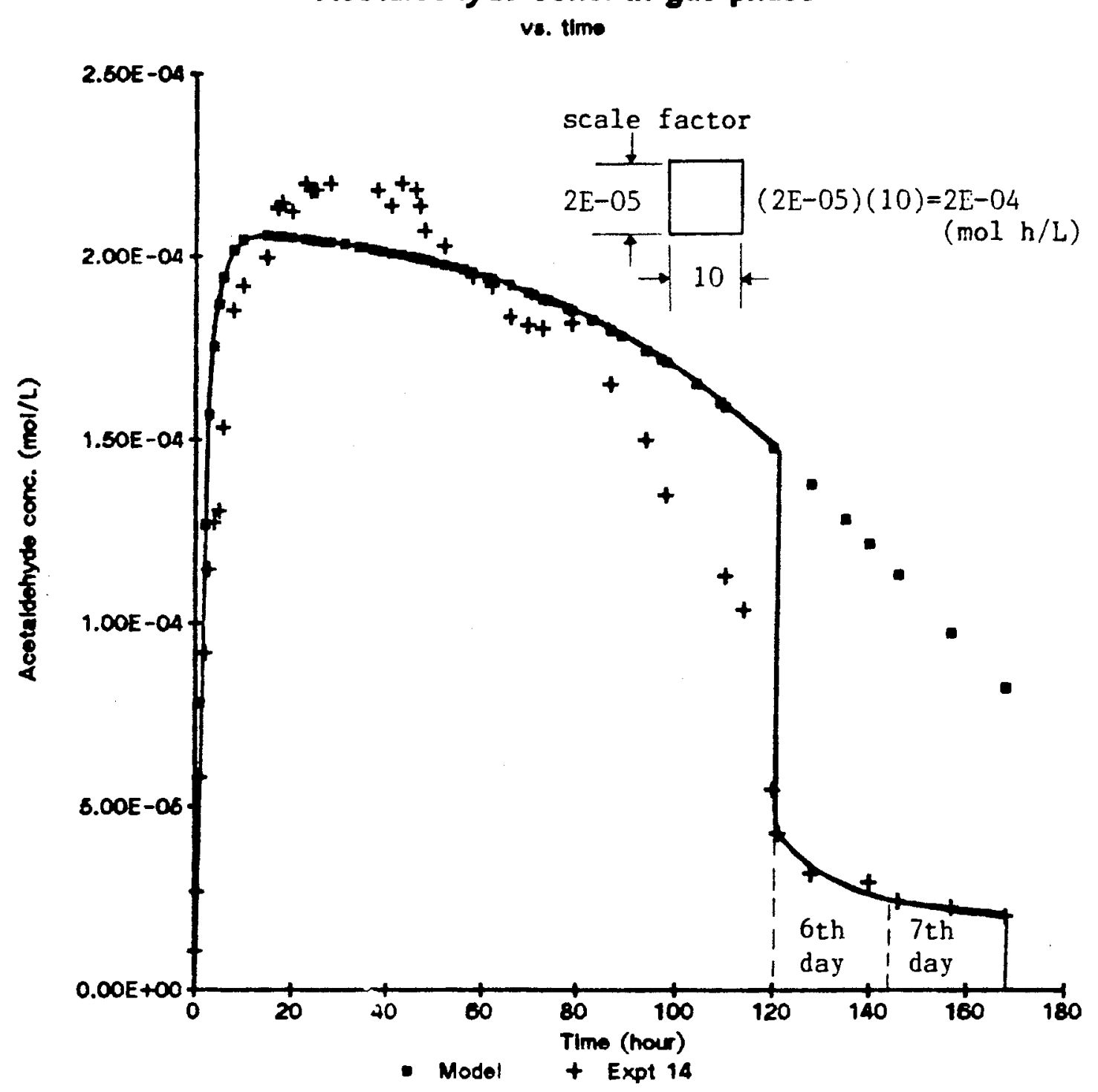

Figure 22. The graphic nethod for total acetaldehyde produced in one batch (case 2). The acetaldehyde concentration profile in the first 5 days is predicted by model, however, the experimental data is used in the 6 th and 7 th days. 
TABLE 8

THE DAILY ACETALDEHYDE PRODUCTION OF ALL

THREE BATCHES OPREATBD IN SEQJUC:

\begin{tabular}{|c|c|c|c|c|}
\hline Day & Batch 1 & Batch 2 & Batch 3 & $\begin{array}{c}\text { Total } \\
(\operatorname{mol} \cdot h / L)\end{array}$ \\
\hline $\begin{array}{r}1 \\
2 \\
3 \\
4 \\
5 \\
6 \\
7 \\
8 \\
9 \\
10 \\
11 \\
12 \\
13 \\
14 \\
15 \\
16 \\
17 \\
18 \\
19 \\
20 \\
21 \\
22 \\
23 \\
24 \\
25\end{array}$ & $\begin{array}{c}0.004480 \\
0.004840 \\
0.004640 \\
0.004320 \\
0.003840 \\
0.000512 \\
0.000352 \\
0.004480 \\
0.004840 \\
0.004640 \\
0.004320 \\
0.003840 \\
0.000512 \\
0.000352 \\
0.004480 \\
\ldots \ldots \\
\ldots \ldots \\
\ldots \ldots\end{array}$ & $\begin{array}{c}0.004480 \\
0.004840 \\
0.004640 \\
0.004320 \\
0.003840 \\
0.000512 \\
0.000352 \\
0.004480 \\
0.004840 \\
0.004640 \\
0.004320 \\
0.003840 \\
0.000512 \\
0.000352 \\
\ldots \\
\ldots \\
\ldots\end{array}$ & $\begin{array}{c}0.004480 \\
0.004840 \\
0.004640 \\
0.004320 \\
0.003840 \\
0.000512 \\
0.000352 \\
0.004480 \\
0.004840 \\
0.004640 \\
0.004320 \\
0.003840 \\
0.000512 \\
0.000352 \\
\ldots \\
\ldots \ldots \\
\ldots . .\end{array}$ & $\begin{array}{c}0.004480 \\
0.009320 \\
0.013960 \\
0.013800 \\
0.012800 \\
0.008672 \\
0.004704 \\
0.000864 \\
0.004832 \\
0.009320 \\
0.013960 \\
0.013800 \\
0.012800 \\
0.008672 \\
0.004704 \\
0.000864 \\
0.004832 \\
\ldots . \\
\ldots . \\
\ldots \ldots \\
\ldots \ldots \\
\ldots \ldots \\
\ldots \ldots\end{array}$ \\
\hline
\end{tabular}




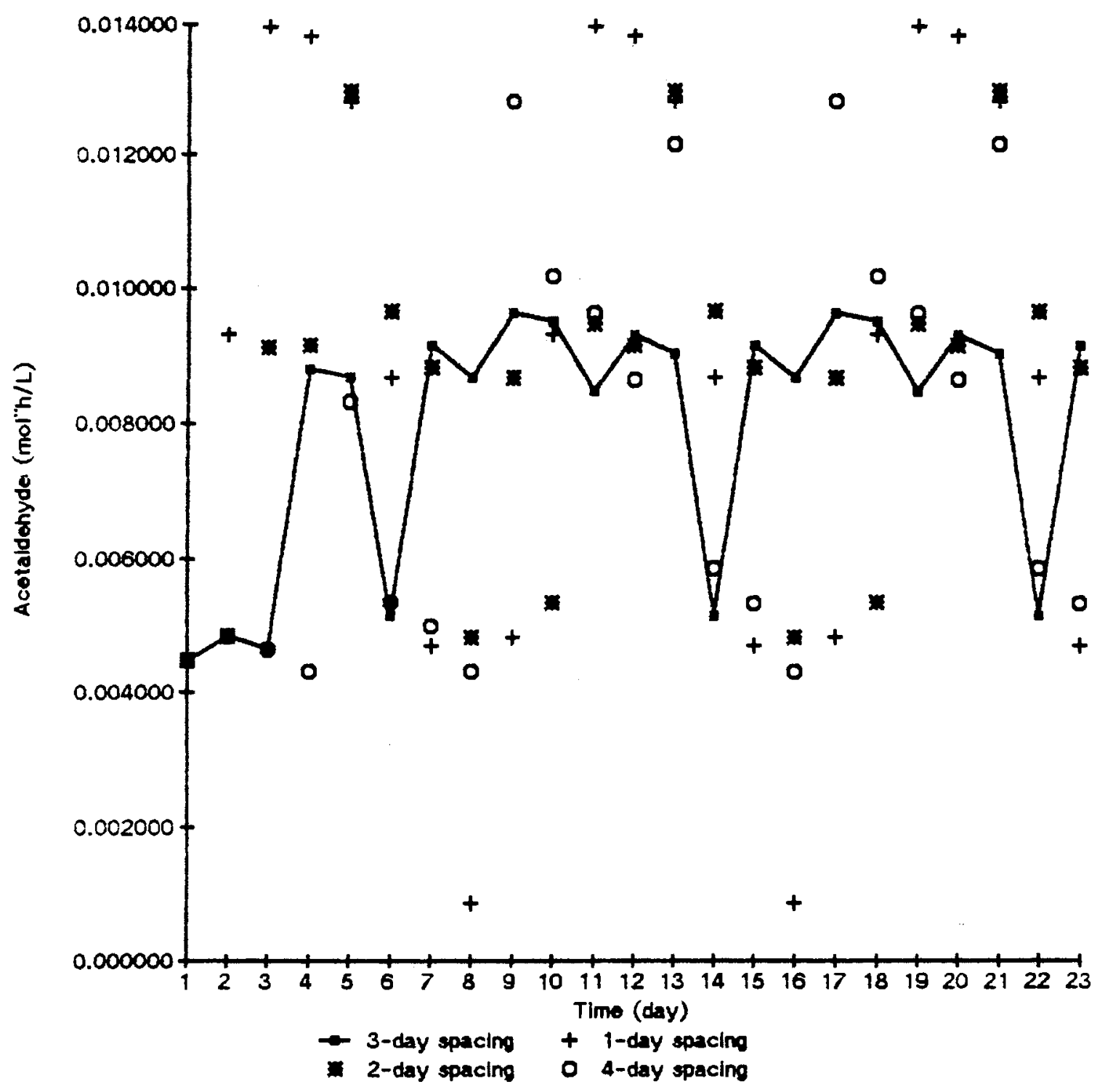

Figure 23. The daily acetaldehyde production rate for all three batches operated in sequence. 
Example

At 61 st hour, $0.5 \%$ old cells (group 1 ) is withdrawn and its activity is 0.9179 . At the same time, $0.5 \%$ new cells (group 2) has been introduced, its activity is assumed to be 1 . Then,

Activity at $61 \mathrm{st}$ hour $=0.995 \cdot 0.9179+0.005 \cdot 1=0.9183$ At $62 \mathrm{st}$ hour, $0.5 \%$ of cells in 61 th hour has been withdrawn and $0.5 \%$ new cells (group 3 ) has been fed, then

$$
\begin{aligned}
& \text { Activity at } 62 \text { st hour }=C_{f} \mathbf{r}_{1} \Phi_{1}+C_{f} r_{2} \Phi_{2}+C_{f} \mathbf{r}_{3} \Phi_{3} \\
& C_{f \times 1} \Phi_{1}=[0.995 \cdot(1-0.005)] \cdot 0.9154=0.906269 \\
& \mathrm{C}_{\mathrm{fr} 2 \Phi 2}=[0.005 \cdot(1-0.005)] \cdot 0.9995=0.004973 \\
& \mathrm{C}_{\mathrm{f} \times 3 \Phi_{3}}=0.005 \cdot 1=0.005
\end{aligned}
$$

where,

$0.9154,0.9995$ and 1 in eq $(29),(30)$ and (31) are the enzyme activity of group 1,2 and 3 at the 62 nd hour. So,

Activity at 62 nd hour $=(0.906269+0.004973+0.005)$

$$
=0.9162
$$

In using this algorithm, the enzyme activity can be predicted in extended operation and the semi-batch reactor in case(1) or (2) becomes a chemostat (continuous CSTR). The enzyme activity vs. time for three different cell withdrawal (input) rates is shown in Fig 24 . When steadystate is reached, the enzyme activity becomes constant, the value for each one is

0.4911 for $(0.5 \%$ cell withdrawn and fed)/hr 
Enzyme Activity vs. Time

with Now Cell input at Both hour

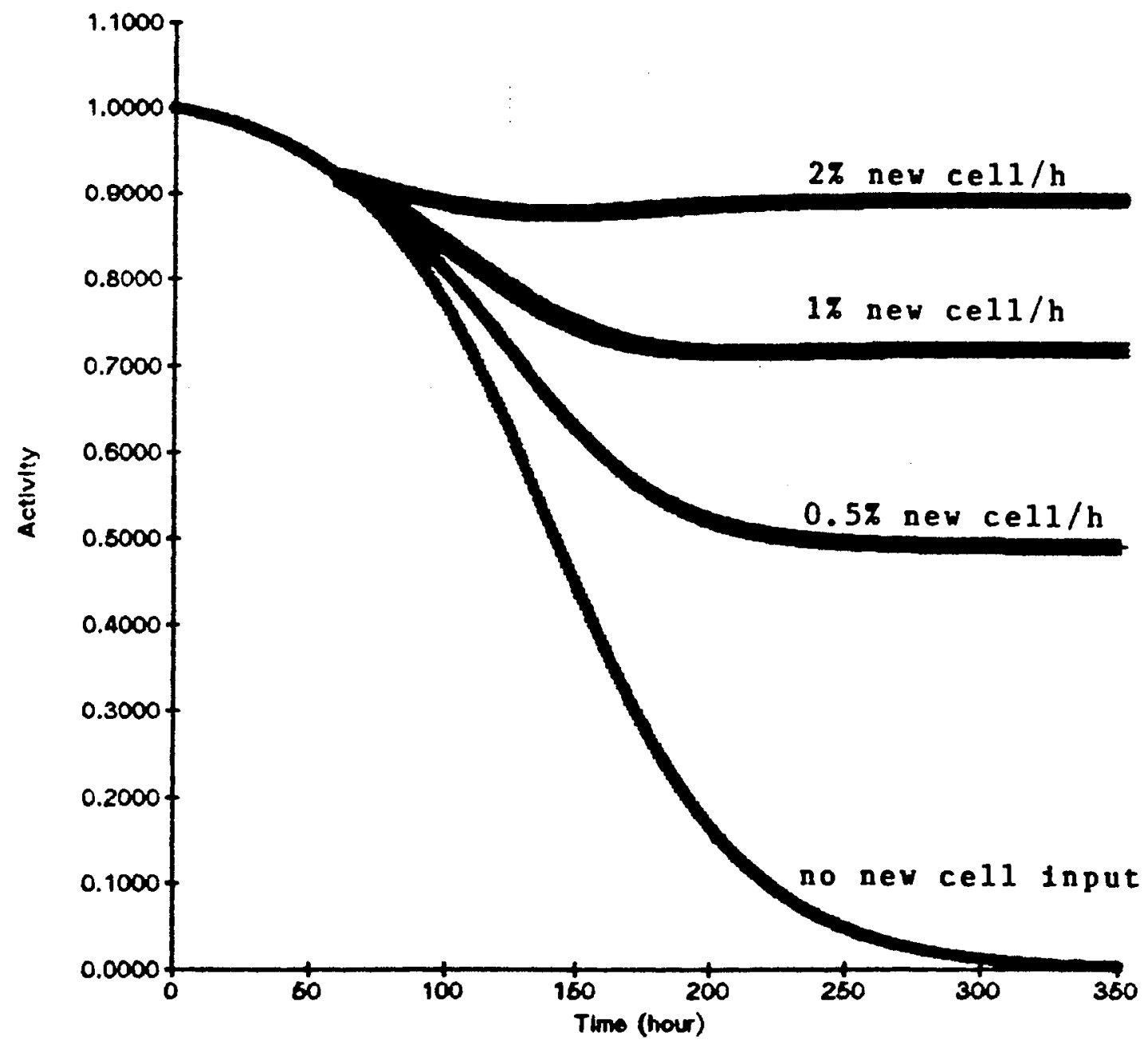

Figure 24. The enzyme activity rs. time for three different cell withdrawn/fed strategies. 
0.7186 for $(1.0 \%$ cell withdrawn and fed $) / \mathrm{hr}$ 0.8928 for $(2.0 \%$ cell withdrawn and fed $) / \mathrm{hr}$ Thus, the acetaldehyde concentration profile vs. time can be predicted by using eq (23) and (24) in Chapter V, as shown in Fig 25. The steady-state acetaldehyde concentration for these three cell feeding strategies are

$$
\begin{aligned}
& \left.\begin{array}{l}
\mathrm{Ca}=0.02434 \mathrm{~mol} / \mathrm{L} \\
\mathrm{Ca} *=1.1571 \cdot 10-4
\end{array}\right] \ldots \ldots \quad 0.5 \% \text { cell withdrawn/fed } \\
& \left.\begin{array}{l}
\mathrm{Ca}=0.03326 \mathrm{~mol} / \mathrm{L} \\
\mathrm{Ca} *=1.5811 \cdot 10-4
\end{array}\right] \ldots \ldots \quad 1.0 \% \text { cell withdrawn/fed } \\
& \left.\begin{array}{l}
\mathrm{Ca}=0.03979 \mathrm{~mol} / \mathrm{L} \\
\mathrm{Ca} *=1.8915 \cdot 10-4
\end{array}\right] \ldots \ldots 2.0 \% \text { cell withdrawn/fed }
\end{aligned}
$$

Thus, the reactor volume can be calculated (eq (26)) as before, the results are summarized as below

<a> $0.5 \%$ cell fed/withdrawn

$\mathrm{V} \approx 252000 \mathrm{liters}$ for $75000 \mathrm{gal} / \mathrm{yr}$ acetaldehyde

$\mathrm{V} \approx 420000$ liters for $125000 \mathrm{gal} / \mathrm{yr}$ acetaldehyde

$\mathrm{V} \approx 671200$ liters for $200000 \mathrm{gal} / \mathrm{yr}$ acetaldehyde

〈b〉 $1.0 \%$ cell fed/withdrawn

$\mathrm{V} \approx 184000$ liters for $75000 \mathrm{gal} / \mathrm{yr}$ acetaldehyde

$\mathrm{V} \approx 307000$ liters for $125000 \mathrm{gal} / \mathrm{yr}$ acetaldehyde

$\mathrm{V} \approx 491000$ liters for $200000 \mathrm{gal} / \mathrm{yr}$ acetaldehyde

<c> $2.0 \%$ cell fed/withdrawn

$\mathrm{V} \approx 154000$ liters for $75000 \mathrm{gal} / \mathrm{yr}$ acetaldehyde

$\mathrm{V} \approx 257000$ liters for $125000 \mathrm{gal} / \mathrm{yr}$ acetaldehyde

$\mathrm{V} \approx 411000 \mathrm{liters}$ for $200000 \mathrm{gal} / \mathrm{yr}$ acetaldehyde 
Acetaldehyde Concen. Profile with

Continuous Now Cell input at 60th hr

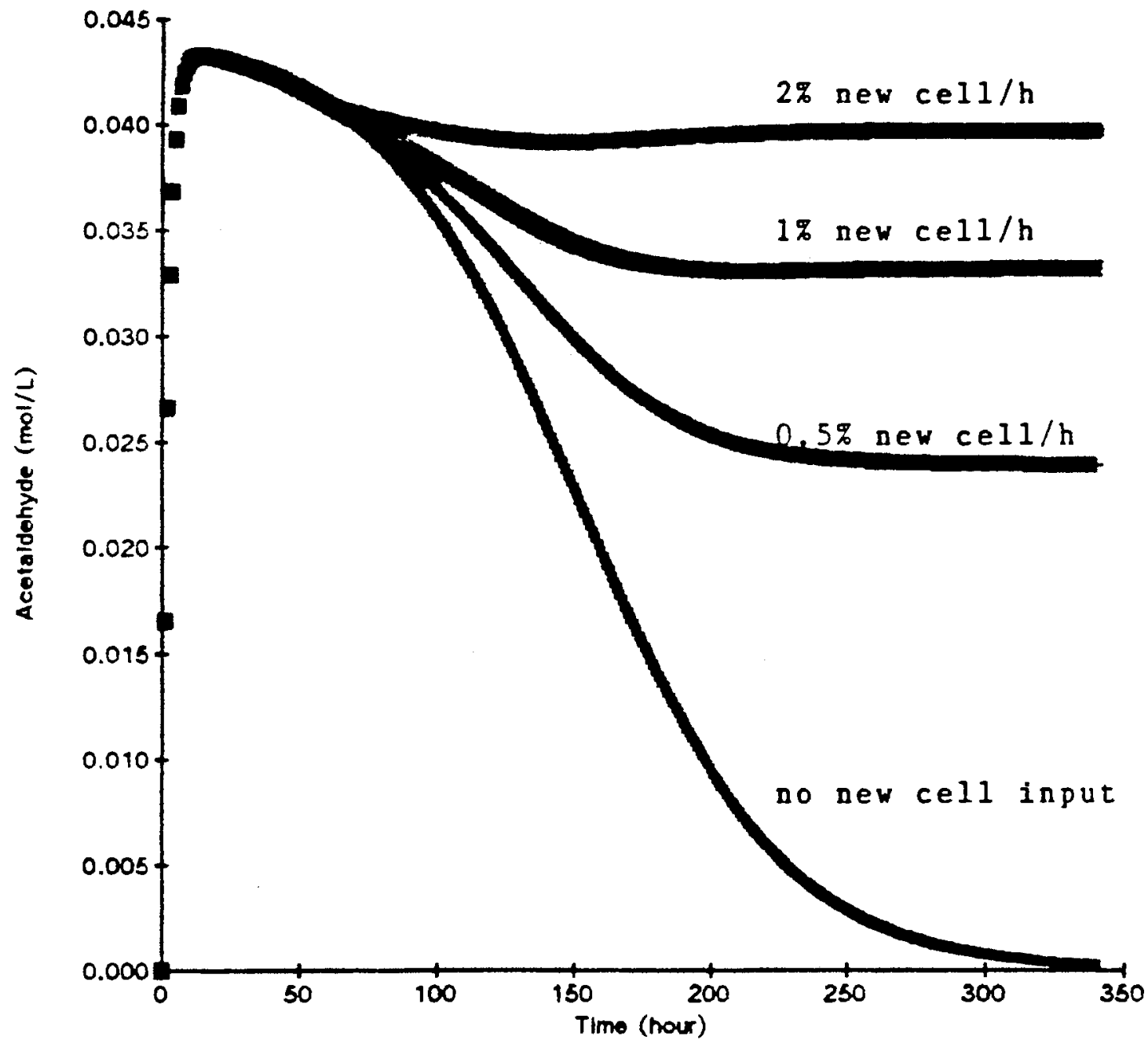

Figure 25. The acetaldehyde conc. profile rs, time for three different cell withdrawn/fed strategies. 
Economic Evaluation of Acetaldehyde Bioprocess

Three processes have been studied and the economic evaluation of each one will also be discussed. These processes [37-40] were designed to produce 125,000 gal/yr acetaldehyde and the flowsheet for each process was shown on Fig 25. The fermentor in each process was operated at 1 atm, $30^{\circ} \mathrm{C}$ and $\mathrm{pH}=7$.

\section{Process Description}

The Pichia pastoris whole cells were stored in seed $\operatorname{tank}(D C W=120 \mathrm{~g} / \mathrm{L})$ and were transferred by air pressure to the main fermentor to form $10 \%$ whole cell, $10 \%$ ethanol and $80 \%$ water solution. For process $\langle 1\rangle$ or $\langle 2\rangle$, the fermentor was operated on a one-week batch cycle to produce 125,000 gal/yr. However, process <3> was operated continuously ( 300 days/year) with cells withdrawn/fed beginning in the 61 st hour to maintain high cells activity.

A mixing tank was provided for ethanol and water to serve the initial ethanol concentration of $10 \%(80 \mathrm{~g} / \mathrm{L})$ and to control the ethanol concentration at $80 \mathrm{~g} / \mathrm{L}$ ' in extended operation. The contents of the mixing tank were pumped through the sterilizer into the fermentor.

The volumetric air flow rate (liter/min) was equal to the broth volume and was sparged through the fermentor to provide enough oxygen for reaction. The product, unreacted ethanol and water stripped out by air passed through a 


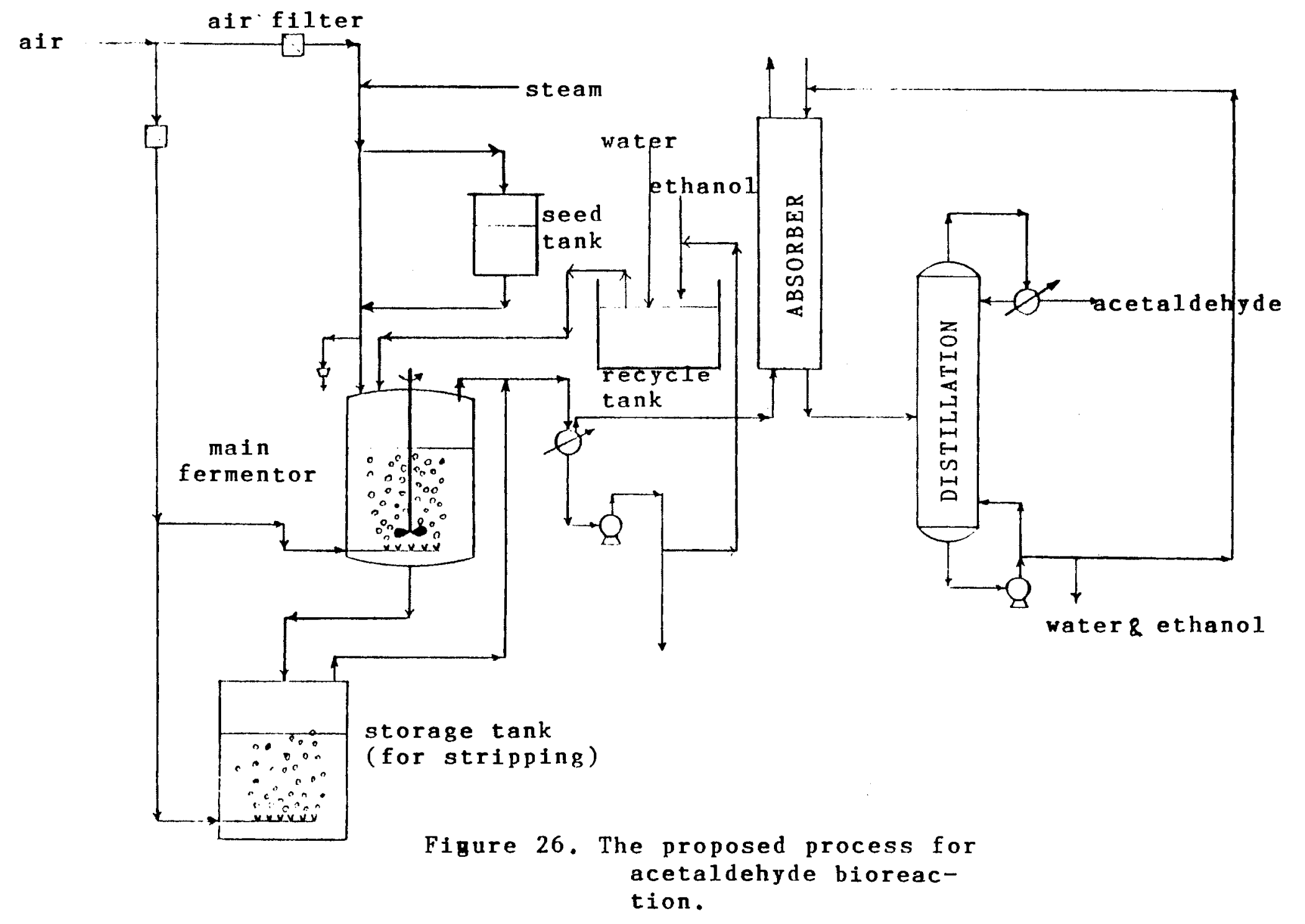


condenser at $-10^{\circ} \mathrm{C}$, of which $6 \%$ of acetaldehyde, $60 \%$ ethanol and $80 \%$ of water were condensed. These values for acetaldehyde, ethanol and water condensed were based on the expermental data. The condensate was then recycled to the mixing tank. Uncondensed acetaldehyde was purified through an absorber and distillation column, it was assumed $60 \%$ of acetaldehyde could be recovered. Since the purification process was out of the scope of this study, only a rough estimation of cost is furnished.

After each batch operation, the residual broth was pushed out by air to a storage tank, and air was supplied to strip the residual ethanol $(80 \mathrm{~g} / \mathrm{L})$ and acetaldehyde $(2 \mathrm{~g} / \mathrm{L})$ into the purification pipeline. Material balance for each process is tabulated and is given in Appendix F.

\section{Estimation of Cost}

Capital cost for each process is listed in Table 9-11 and the production costs are in Table 12-14 [41-45]. Based on the same amount of acetaldehyde production, 125,000 gal/yr, process <2> is not superior to process $\langle 1\rangle$, because of an increase in capital cost without an increase in production cost. It is interesting to find that process < 3$\rangle$ is worse than process $\langle 1\rangle$ or $\langle 2\rangle$ even though it is operated continously. The main reason is the high whole cell cost and low specific enzyme activity in this bioprocess.

The break even price for acetaldehyde is $\$ 2.1 / 1 b$ (about 5 times of present synthesized price) for 125,000 gal/yr 
acetaldehyde produced; the interest on capital cost is not included. The break even point for this process $\langle 1\rangle$ is about one year if acetaldehyde saled at $\$ 4.0 / 1 b$, based on $80 \%$ plant financed over 7 years at an annual interest rate of $15 \%$.

If the specific activity of whole cell can be enhanced then this process has the potential for commercial production. 
TABLE 9

ESTIMATION OF CAPITAL COST

(CASE 1)

Item description

cost

Fermentor, $320 \mathrm{~m} 3,304$ SS

$\$ 300,000$

Agitator, $25 \mathrm{hp}$, medium rpm, dual impeller

$\$ 38,000$

Seed tank, $25 \mathrm{~m} 3,304$ sS

$\$ 12,000$

Mixing tank, $10 \mathrm{~m} 3,304$ SS

$\$ 23,000$

Storage tank, ethanol, recycle, $100 \mathrm{~m} 3,304 \mathrm{sS} \$ 30,000$ recycle, $100 \mathrm{~m} 3,304$ SS

Storage tank, acetaldehyde, $20 \mathrm{~m} 3,304 \mathrm{sS}$ \$4,000

Sterilizer, 304 SS

$\$ 30,000$

Compressor

$\$ 20,000$

Pump

$\$ 5,000$

Distillation column

$\$ 65,000$

Absorber

$\$ 120,000$

Condenser

$\$ 16,000$

$\$ 663,000$ 
TABLE 10

ESTIMATION OF CAPITAL COST

(CASE 2)

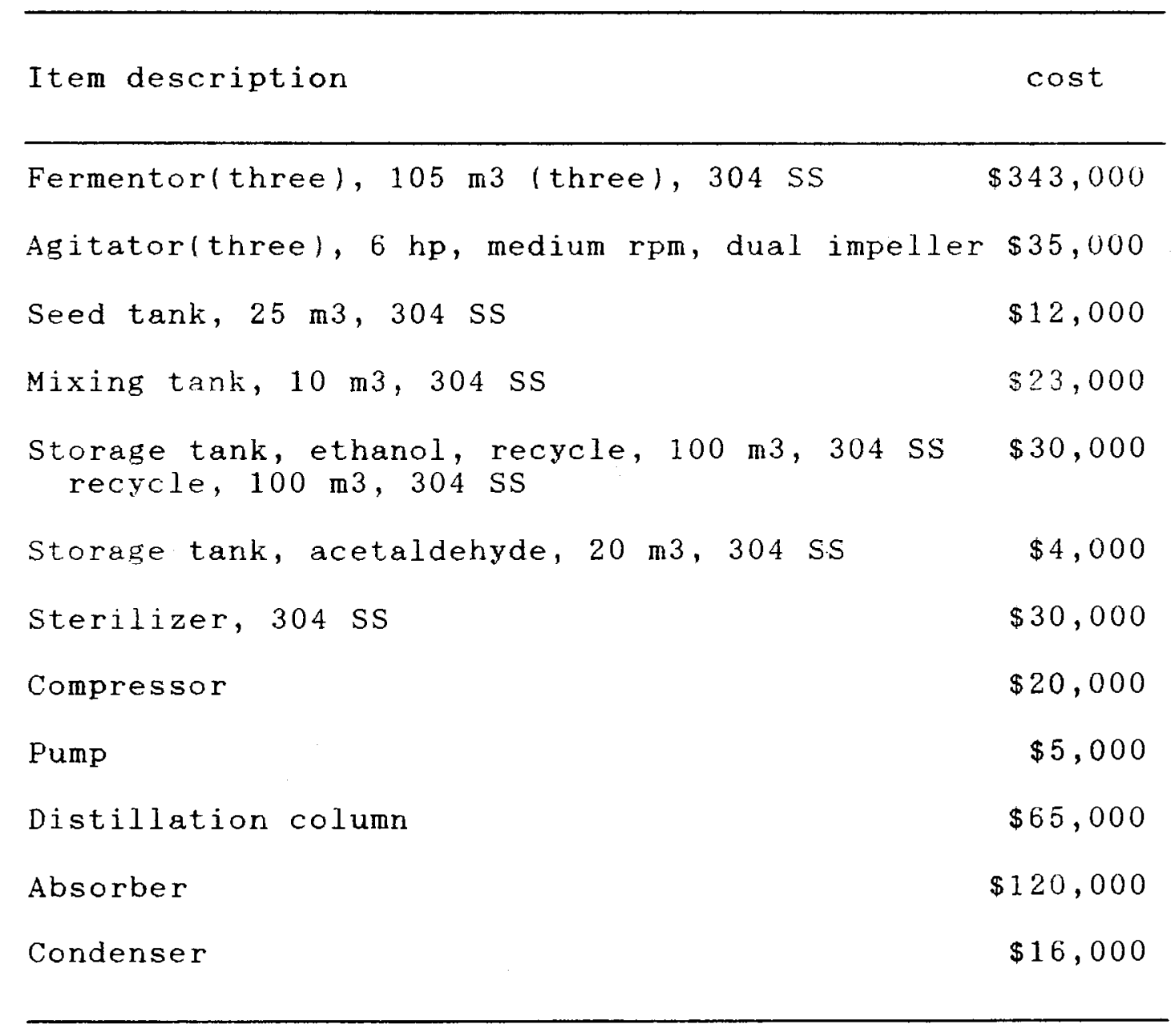

$\$ 703,000$ 
TABLE 11

ESTIMATION OF CAPITAL COST

FOR 2\% CELL WITHDRAWN/FED

(CASE 3)

Item description

$\cos t$

Fermentor, $257 \mathrm{~m} 3,304$ SS

$\$ 280,000$

Agitator, $20 \mathrm{hp}$, medium rpm, dual impeller

$\$ 31,000$

Seed tank, $25 \mathrm{~m} 3,304$ SS

$\$ 12,000$

Mixing tank, $10 \mathrm{~m} 3,304$ SS

$\$ 23,000$

Storage tank, ethanol, recycle, $100 \mathrm{~m} 3,304$ SS recycle, $100 \mathrm{~m} 3,304 \mathrm{SS}$

Storage tank, acetaldehyde, $20 \mathrm{~m} 3,304$ SS

$\$ 4,000$

Sterilizer, 304 SS

$\$ 30,000$

Compressor

$\$ 20,000$

Pump

$\$ 5,000$

Distillation column

$\$ 65,000$

Absorber

$\$ 120,000$

Condenser

$\$ 16,000$

$\$ 636,000$ 
TABLE 12

ESTIMATION OF PRODUCTION COST

(CASE 1)

Item description

$\operatorname{cost}$

\begin{tabular}{lr} 
Raw materials & \\
Pichia whole cell, $\$ 0.4 / \mathrm{kg}$ & $\$ 422,000$ \\
Ethanol, fermentation, $\$ 0.35 / \mathrm{kg}$ & $\$ 537,000$ \\
Utilities and waste disposal & $\$ 180,000$ \\
Labor-dependent cost & $\$ 260,000$ \\
Capital-dependent items & $\$ 88,000$ \\
Maintenance( $2 \%$ DFC) & $\$ 145,000$ \\
Insurance + taxes (7\%) & $\$ 99,000$ \\
Depreciation (15\% DFC) & Total \\
\hline
\end{tabular}


TABLE 13

ESTIMATION OF PRODUCTION COST

(CASE 2 )

\begin{tabular}{lc}
\hline Item description & cost \\
\hline Raw materials & \\
$\quad$ Pichia whole cell, $\$ 0.4 / \mathrm{kg}$ & $\$ 422,000$ \\
Ethanol, fermentation, $\$ 0.35 / \mathrm{kg}$ & $\$ 537,000$ \\
Ltilities and waste disposal & $\$ 180,000$ \\
Labor-dependent cost & $\$ 500,000$ \\
Capital-dependent items & $\$ 88,000$ \\
Maintenance( $2 \%$ DFC) & $\$ 145,000$ \\
Insurance + taxes ( & \\
Depreciation (15\% DFC) & $\$ 99,000$ \\
\hline
\end{tabular}


TABLE 14

$\begin{array}{ll}\text { ESTIMATION } & \text { OF PRODUCTION COST } \\ \text { (CASE 3) }\end{array}$

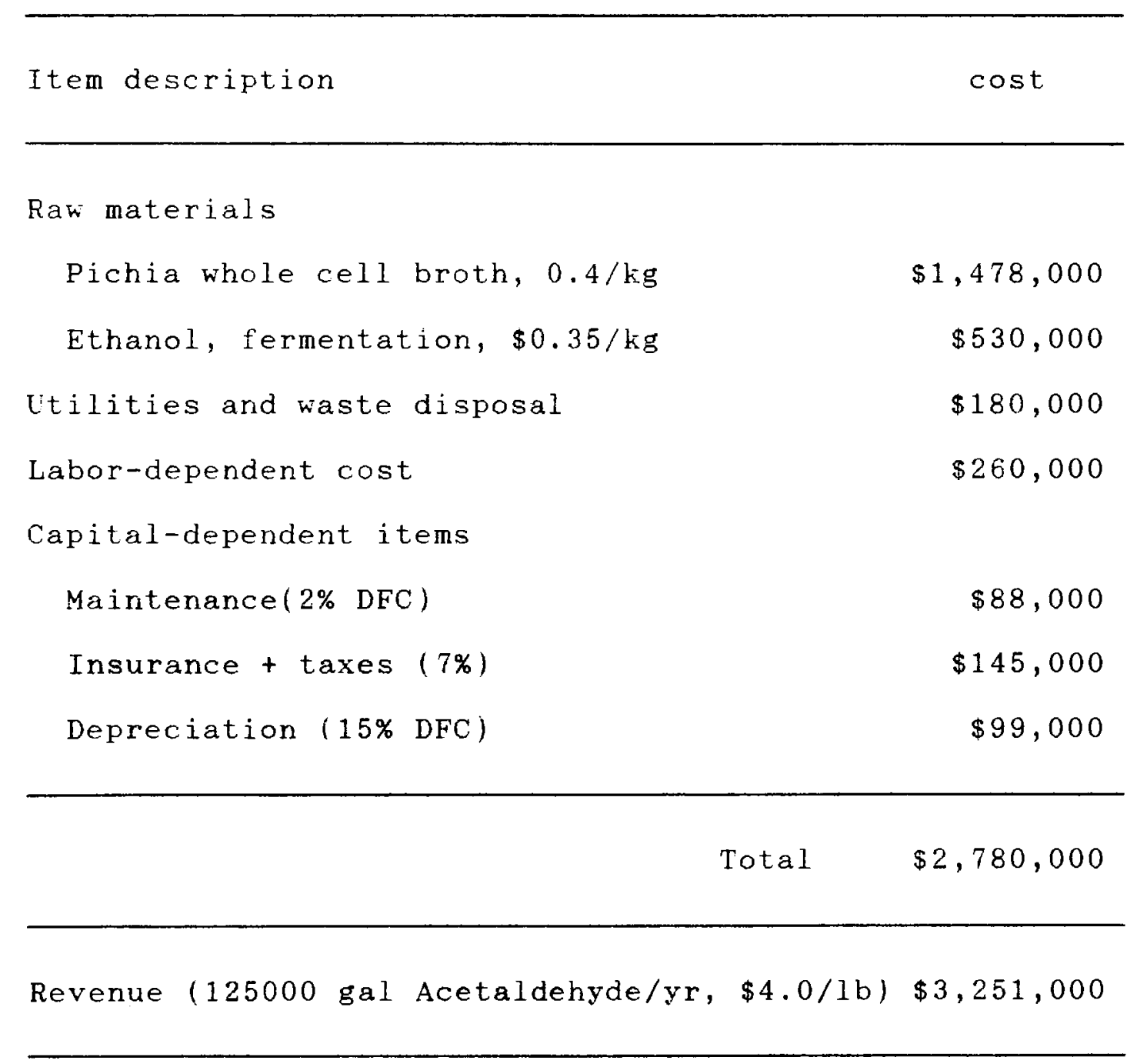


CHAPTER VII

CONCLUSIONS AND RECOMMENDATIONS

The research examines both the technical and economic feasibility of producing "natural, food grade" acetaldehyde from ethanol by using Pichia Pastoris non-growing whole yeast cells.

\section{Conclusions}

1. The optimal operating conditions for this process are $7.5 \mathrm{pH}$ and $10 \%$ (best of $5 \%, 10 \%$, and $15 \%$ ) ethanol concentration. A temperature of $30^{\circ} \mathrm{C}$ is acceptable, but may not be the optimum temperature.

2. Both the substrate, ethanol, and product, acetaldehyde, inhibitions occur simultaneously in this bioreaction. Acetaldehyde inhibition is severe when its concentration is over $4.0 \mathrm{~g} / \mathrm{L}(50 \%$ inhibition).

3. Alcohol oxidase is sensitive to oxygen concentration. High oxygen concentration offers high acetaldehyde production rate but it also causes the enzyme deactivation to proceed quickly. In general, this study is under oxygen limitation in order to prolong the enzyme activity in extended operation.

4. Acetaldehyde recovery is a big problem, a method must be 
developed to overcome this (tris buffer or sulfuric hydroxylamine).

5. The proposed model predicts well in the first 120 hours operation which is considered for full scale process design. However, the proposed model has some limitations, such as (1) it doesn't include the effect of oxygen concentration on rate equation, thus this model can be applied only for pure air, (2) the deactivity of enzyme should be studied (i.e. the enzyme activity as a function of time) since the inactivity term in this model uses the data by Duff and Murray and, (3) this model doesn't include the effects of temperature and agitation speed on the rate equation.

6. A cell withdrawn/fed process is not able to compete with the batch process due to the high yeast cell cost and low acetaldehyde production rate.

\section{Recommendation}

1. The proposed model needs to be modified for rigorous calculation. That is, the effect of temperature, oxygen concentration, and agitation speed on acetaldehyde production rate should be studied and included in future models.

2. Extensive studies about the effect of oxygen concentration on alcohol oxidase should be performed. Because oxygen concentration is the determinate factor in this study and a function of gas flow rate, temperature and agitation speed. 
3. A high specific activity of alcohol oxidase (detergenttreated cell) with strong resistance to acetaldehyde inhibition is the key for commercial application.

4. A prevented inactivation or regenerated activity chemical ( $\beta$-mercaptoethanol) needs to be studied to regenerate the enzyme activity.

5. The cell withdrawn/fed strategy needs to be modified in order to compete with batch reactor. In this study, the withdrawn cells are simply taken out to a storage (stripping) tank without further processing for recycle. It might be possible to use a filter or membrane separator to separate the cells and liquid. The cells can then stay in the reactor and continue to produce acetaldehyde. At same point this will require a purge of the built-up cell mass. 


\section{BIBLIOGRAPHY}

1. Byrne, B. and Shermen, G, . Food Technology, pp. 57-61 $(1984)$.

2. Guilbault, G. G., Enzymatic Methods of Analysis, Pergamon Press, New York (1970).

3. Aguilo, A. and Penrod, J. D., Encyclopedia of Chemical Processing and Design, pp. 114-162, Vol.1, Marcel Dekker, Inc., New York (1976).

4. Smidt, J., et al., Angew. Chem., Vol. 71, pp.176-182 $(1959)$.

5. Windholz, M., Editor, Merck Index, Tenth Edition, pp.6 $(1983)$.

6. Kulaev, I. S. and Vagabov, V. M., Advances in Microbial Physiology, pp.1-81, Academic Press, London (1983).

7. Ellis, S. B., et al., Molecular and Cellular Biology, pp. 1111-1121 (1985).

8. De Duve, C., Annals of the New York Academy of Sciences, pp.369 (1969).

9. Bromann, C. and Sahn, H. , Archives of Microbiology, Vol. 117 , pp. 67 (1978).

10. Sahm, H. and Wagner, Fritz, Eur. J. Biochem., Vol. 36 , pp.250-256 (1973).

11. Hopkins, T.R., U.S. Patent 4,540,668 (1985).

12. Hoiberg, D.A., Hatfield, G.W., and Moyed, H.S., PCT (World Intellectual Property Organization) WO87/04725 (1987).

13. Guilbault, G.G. and Kauffmann, J.M., Biotechnology and Biochemistry, vol. 9, pp.95-113 (1987). 
14. Barzana, E., Klibanov, A.M., and Karel, M., Applied Biochemistry and Biotechnology, vol. 15, pp.25-34 $(1987)$.

15. Boeiu, G.G., Dordick, J.S., and Klibanov, A.M., Biotechnology, Vol. 4, pp.997-999 (1986).

16. Duff, S.J.B. and Murray, W.D., Biotechnology and Bioengineering, Vol.31, pp.44-49 (1988).

17. Kierstan, M., Biotechnology and Bioengineering, Vo1.24, pp. 2275-2277 (1982).

18. Duff, S.J.B. and Murray, D., Biotechnology and Bioengineering, Vol.31, pp.790-795 (1988).

19. Couderc, R. and Baratt, J., Biotechnology and Bioengineering, Vol.22, pp.1155-1173 (1980).

20. Tani, Y., Biotechnology and Genetic Engineering Reviews, Vol.3, pp.111-135 (1985).

21. Klibanov, A.M., Advances in Applied Microbiology, Vol.29, pp. 1-28 (1983).

22. Personal communication with Phillips researchers, May 16, 1988, Phillips Petroleum Company, Battlesville, Ok lahoma.

23. Raymond, W.R., US Patent 4,481,292 (1984).

24. Couderc, R. and Baratti, J., Agricultural Biological Chemistry, Vol.44, pp.2279-2289 (1980).

25. Wecker, M.S.A. and Zal1, R.R., Applied Enviromental Microbjology, Vol.53, pp.2815-2820 (1987).

26. Bormann, C. and Sahm, H., Archives of Mocrobiology, V.117, pp.67(1978).

27. Armstrong, D.W., Martin, S.M., and Yamazaki, Hiroshi, Biotechnology Letters, Vol.6, pp.183-188 (1984).

28. Reid, R.C., Prausnitz, J.M., and Sherwood, T.K., The Properties of Gases and Liquids, McGraw-Hi11, New York (1980).

29. Smith, J.M., Introduction to Chemical Engineering Thermodynamics, MCGraw-Hi11, New York (1987). 
30. Gmenling, J., Onken, U., and Arlt, W., Vapor-Liquid Equilibrijum Data Collection, Chemistry Data Series, Vol.I, Parts 1-8 (1977-1984).

31. Gmehling, J., Rasmussen P., and Fredenslund, A., Ind. Eng. Chem. Process. Des. Dev., Vol.21, pp.118 $(1982)$.

32. Bailey, J.E. and 011 is, D.F., Biochemical Engineering Fundamenta1s, McGraw-Hi11, New York (1986).

33. Van Den Heuve1, J.C. and Beeftink, H.H., Biotechnology and Bioengineering, Vol.31, pp.718-724 (1988).

34. Han, Keehyun and Levenspie1, 0., Biotechnology and Bioengineering, Vo1.32, pp.430-437 (1988).

35. Hsu, Teh-An and Tsao, G.T., Biotechnology and Bioengineering, Vol.21, pp.2235-2246 (1979).

36. Sadana, A. and Malhotra, A., Biotechnology and Bioengineering, Vol.30, pp.1041-1056 (1987).

37. Stanbury, P.F. and Whitaker, A., Principles of Fermentation Technology, Pergamon Press, New York $(1986)$.

38. Wang, D.I.C., Fermentation and Enzyme Technology, wiley, New York (1979).

39. Wandrey, C. and Flaschel, E., Advances in Biochemical Engineering, Vol.12, pp.147-218 (1979).

40. Drapeau, D., Blanch, H.W., and Wilke, C.R., Biotechnology and Bioengineering, Vol.30, pp.946953 (1987).

41. Peters, M.S. and Timmerhaus, K.D., Plant Design and Economics for Chemical Engineers, MCGraw-Hi11, New York $(1980)$.

42. Cran, J., Chemical Engineering, April 6, pp.65-79 $(1981)$.

43. Viola, J.L., Chemical Engineering, Aprit 6, pp.80-86 $(1981)$.

44. Hal1, R.S., Matley J., and MCNaughton, K.J., Chemical Engineering, Apri1 5, pp.81-116 (1982).

45. Klumpar, I.V. and Slavsky, Chemical Engineering, Vol.7, pp.73-75 (1985). 


\section{NOMENCLATURE}

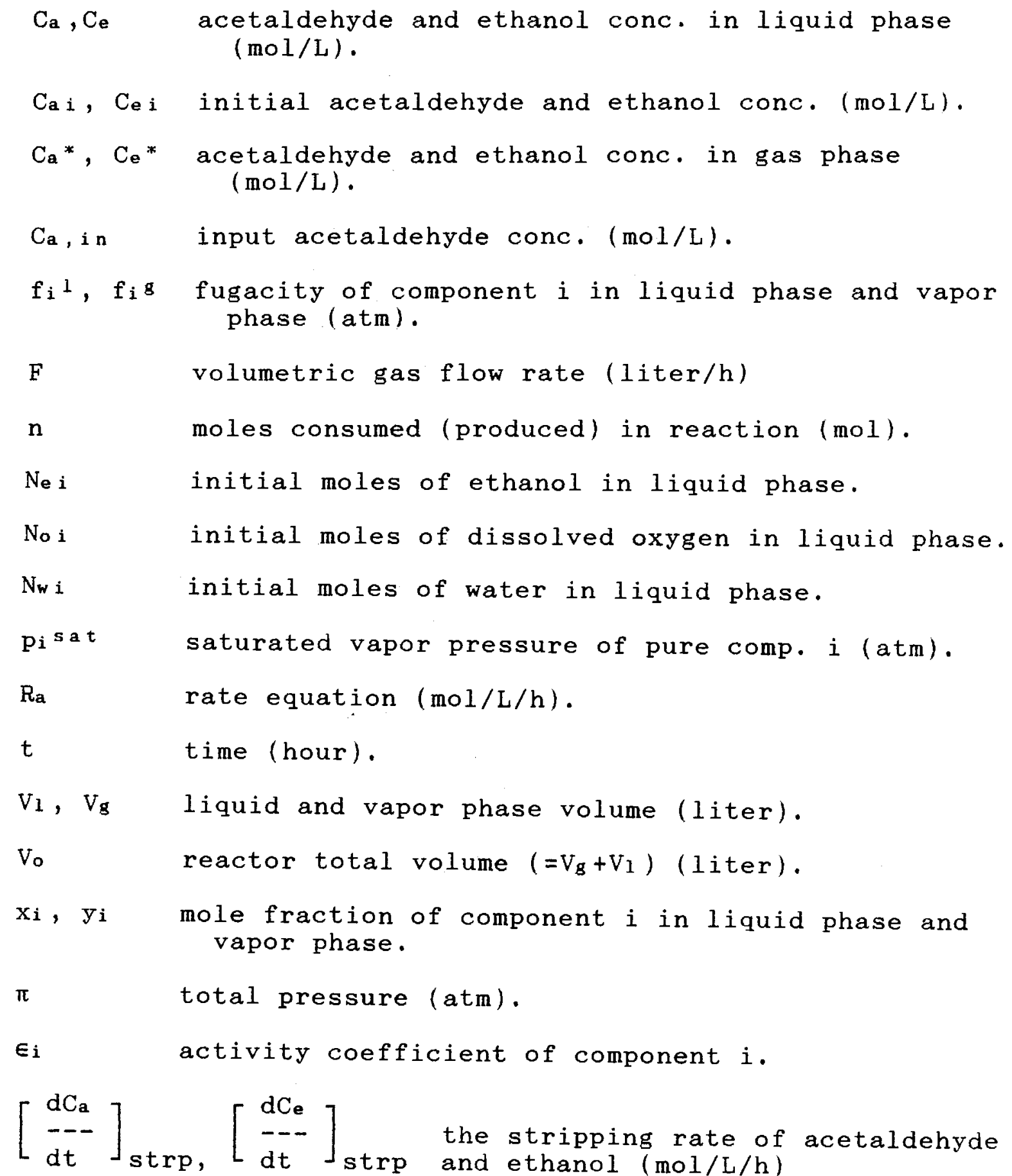


APPENDIX A

FLOW METER CORRELATION FACTOR FOR GASES 
TABLE 15

SPECIFIC GRAVITY

CORRECTION FACTOR FOR GASES

Meter is air Specific Air Helium Ammonia Hydrogen Nitrogen calibrated gravity

\begin{tabular}{lllllll}
\hline Air & 1.00 & 1.00 & 2.69 & 1.30 & 3.81 & 1.01 \\
Helium & 0.138 & 0.37 & 1.0 & 0.48 & 1.41 & 0.38 \\
Ammonia & 0.59 & 0.77 & 2.06 & 1.00 & 2.92 & 0.78 \\
Hydrogen & 0.069 & 0.26 & 0.71 & 0.34 & 1.00 & 0.27 \\
Nitrogen & 0.967 & 0.98 & 2.64 & 1.28 & 3.74 & 1.00 \\
\hline
\end{tabular}


APPENDIX B

STANDARD CALIBRATION CURVE

FOR ETHANOL AND ACETALDEHYDE 
TABLE 16

STANDARD CALBRICATION DATA FOR ACETALDEHYDE AND ETHANOL

\begin{tabular}{ccc}
\hline \multirow{2}{*}{$\begin{array}{c}\text { Concentration } \\
\text { by volume })\end{array}$} & Acetaldehyde & Ethanol \\
\cline { 2 - 3 } $1 \%$ & 28193 & 40662 \\
$2 \%$ & 56065 & 79132 \\
$4 \%$ & 101082 & 147521 \\
$10 \%$ & 266138 & 387963 \\
\hline
\end{tabular}

* The data were the average for at least three injections for each concentration.

* The sample volume was ten $\mu l$ analyzed by HP 5880A GC. 


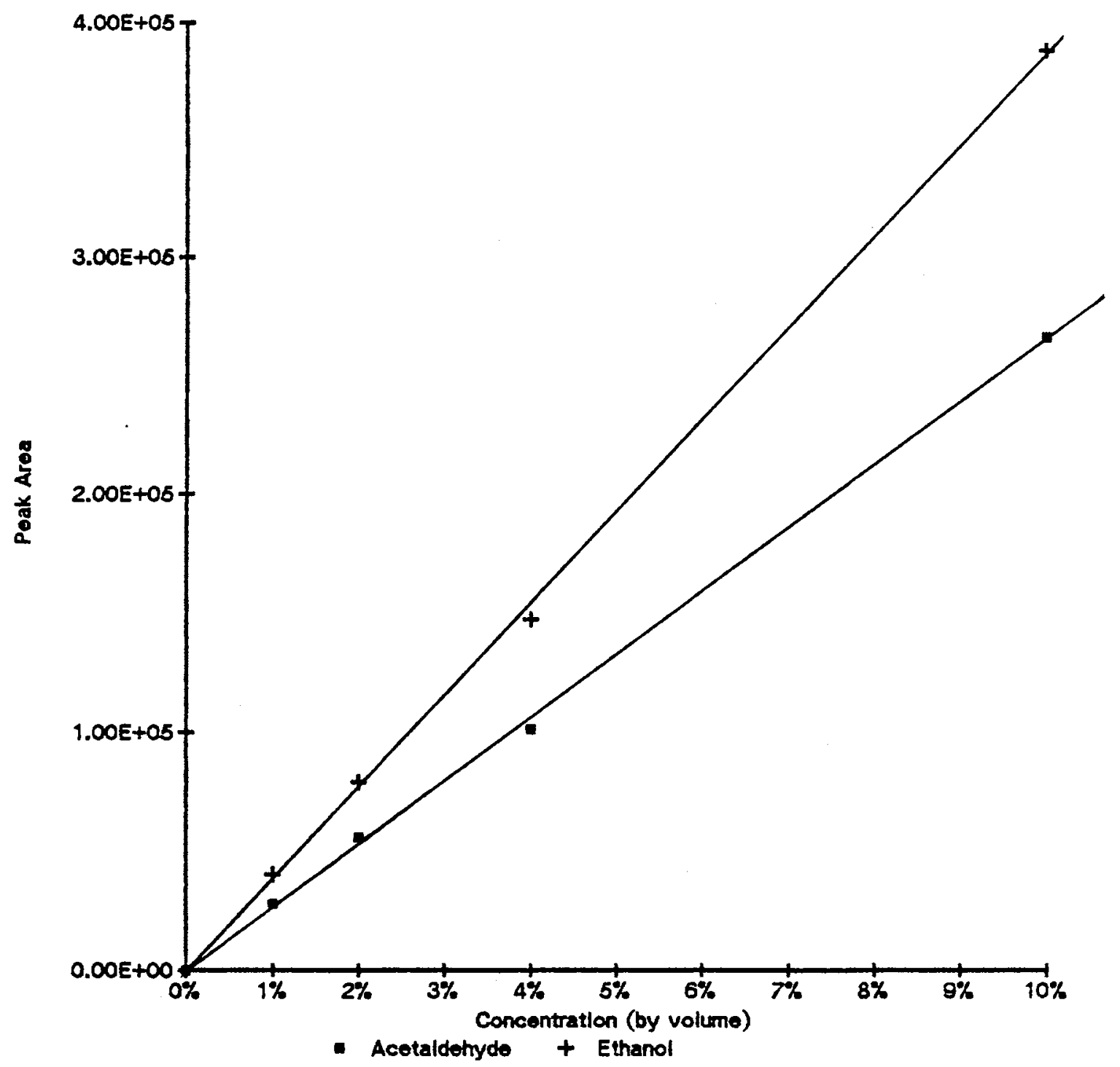

Figure 27. Standard calibration curres for acetaldehyde and ethanol. 
APPENDIX C

DESCRIPTION OF BATCH REACTOR EXPERIMENTS 
Operating conditions for all experiments are listed in Table 7. Experiments 1 to 6 were performed in a 2-liter glass fermentor and experiments 7 to 16 were performed in a 5-liter New Brunswick fermentor. A description of each experiment is given below:

Experiment 1

A 2-liter glass fermentor was filled with $330 \mathrm{ml}$ broth, $330 \mathrm{ml}$ water, and $35 \mathrm{ml}$ ethanol (5\%); for a total volume of $695 \mathrm{ml}$. $0.5 \mathrm{ml}$ antifoam was used. The physical conditions were: air flow, $2,000 \mathrm{cc} / \mathrm{min}$; broth temperature, $30^{\circ} \mathrm{C}$; stirrer speed, $600 \mathrm{rpm}$; isopropanol reservoir, $-20^{\circ} \mathrm{C}$. At this temperature the vapor pressure of acetaldehyde is 120 mmHg. Ethanol concentration was maintained at $5 \%$. Acetaldehyde concentration in the broth reached $0.38 \%(2.97$ $g / L)$ after 5 hours, with no acetaldehyde detected after 12 hours. The material balance indicated that the acetaldehyde collected was $7.5 \%$ of the ethanol utilized.

\section{Experiment 2}

A $50 \%$ broth was used with $10 \%$ ethanol for this experiment. The cold trap reservoir was converted to liquid nitrogen to maintain a temperature $-70^{\circ} \mathrm{C}$. At this temperature the vapor pressure of acetaldehyde is $5 \mathrm{mmHg}$ (see Table 3 in Chapter II). The maximum acetaldehyde concentration in the broth was $1.53 \%(12 \mathrm{~g} / \mathrm{L})$ after seven hours. Quantitative acetaldehyde was detectable after 24 hours $(0.015 \%)$ and traces remained in the broth until 42 
hours. The condensate collected over the first ten hours was $30 \%$ acetaldehyde, with $4 \%$ of the water trap as acetaldehyde. The condensate for the next 12 hours was 14.3\% acetaldehyde. Again we were only able to collect $7.1 \%$ of ethanol used as acetaldehyde product. The utilization rate of ethanol for the first ten hours was 0.042 mole per hour. If all ethanol is converted to acetaldehyde the production rate would be 12.3 grams per 1 iter broth per hour. Over the entire run of the experiment this would produce a potential maximum of 172 grams of acetaldehyde per liter of broth.

\section{Experiment 3}

This trial was with $20 \%$ ethanol in the reactor. The results were clearly below those of $10 \%$ tests. The maximum acetaldehyde in the broth reached $1.32 \%(10.3 \mathrm{~g} / \mathrm{L})$ after 6 hours, dropped steadily through 20 hours and was no longer detectable after 36 hours.

\section{Experiment 4}

This experiment was an attempt to maintain acetaldehyde activity for a longer period by adjusting the air flow rate, strip acetaldehyde from the system, and prevent cell shutdown by high concentrations of acetaldehyde. The conditions of Expt 2 were used. The goal was to prevent acetaldehyde concentrations greater than $1 \%$. To maintain a level below $1 \%$ requires a doubling of the air flow rate to $4,000 \mathrm{cc} / \mathrm{min}$ for three hours. After this time the air flow 
can be reduced. The result did indicate extended activity when compared with Expt 2 , even though the difference is small (about 5 to 8 hours longer). However, there appears to be no improvement in the area under the curve, which is proportional to the total acetaldehyde production rate.

\section{Experiment 5}

The conditions of Expt 4 were repeated. The result was similar to Expt 4

\section{Experiment 6}

The conditions were the same as Expt 4 (or 2) except the gas, air, was replaced by pure oxygen. The results were surprised, the acetaldehyde concentration reached $1.4 \%$ (11 $g / L)$, nearly twice of Expt 5 , in the first hour, and the reaction lasted for 100 hours with detectable acetaldehyde. This did prove that $P$. pastoris whole cell is sensitive to oxygen limitation. Quantitative conversion of 40 grams of ethanol was obtained in the first two hours. If all ethanol is converted to acetaldehyde, the amount of acetaldehyde produced in the first 5 hours would be $90 \mathrm{~g} / \mathrm{L}$.

\section{Experiment 7}

This experiment was performed in a 5-liter New Brunswick fermentor with 2 liters working volume. This fermentor was filled with $180 \mathrm{ml}$ Pichia broth (9\%), (dated 4/12/88 and frozen for one and half months before use), 200 $\mathrm{ml}$ ethanol $(10 \%)$, and $1620 \mathrm{ml}$ water $(81 \%)$, and $1 \mathrm{ml}$ 
antifoam. An oxygen probe and $\mathrm{pH}$ meter were mounted into the fermentor to continuously monitor the DOC (dissolved oxygen concentration) and $\mathrm{pH}$. The result was substantialiy better than previous experiments. The acetaldehyde production rate was nearly constant in the first hour, and the ethanol consumed was $4.5 \mathrm{~g} / \mathrm{L}$. The acetaldehyde concentration reached a maximum after 12 hours and was maintained at this level. In the $86 \mathrm{th}$ hour, the experiment was abandoned due to the blockage in the cold trap.

\section{Experiment 8}

The conditions of Expt 7 were repeated with careful controlied pH of $7.2 \pm 0.04$ (in Expt 7 the pH fluctuated from 7.05 to 7.32 ). The result was slightly better than Expt 7. The maximum acetaldehyde concentration in the broth reached $0.49 \%(3.8 \mathrm{~g} / \mathrm{L})$ after 20 hours, compared to that of $0.36 \%(2.8 \mathrm{~g} / \mathrm{L})$ in Expt 7 . The acetaldehyde concentration maintained almost at the same level with little decrease until the 140th hour, then began to drop rapidly. However, the cells were still able to maintain activity with measurable acetaldehyde $(0.015 \%)$ observed after 186 hours. Again the collected acetaldehyde in the cold trap $\left(-20^{\circ} \mathrm{C}\right)$ was on ly 10\% of the ethanol consumed. If al1 ethanol is converted to acetaldehyde, then this experiment produced more than 800 grams of acetaldehyde after 186 hours of operation. 
Experiment 9

The whole cells were obtained from Phillips Petroleum Company on June 8,1988 . All operating conditions were the same as Expt 7 except $\mathrm{pH}$ was controlled at 7.5 . The result was similar to Expt 8 . The overall operating time was 208 hours and the overall ethanol consumed was 1100 grams.

Experiment 10

The operating conditions were the same as Expt 7 . The initial ethanol consumption rate was $4.6 \mathrm{~g} / \mathrm{L}$ and the acetaldehyde concentration in broth reached $0.077 \%(0.06$ $g / L)$ in the first hour. The maximum product concentration in the broth reached $0.25 \%(2 \mathrm{~g} / \mathrm{L})$ in the $20 \mathrm{th}$ hour. From then on, the concentration kept nearly in the same level with only slightly decrease until the 115 th hour, after this point, it began to drop off very rapidly. Another quisi steady-state was obtained after 125 hours, though the production rate was low and acetaldehyde concentration was about $0.012 \%$ in broth.

\section{Experiment 11}

A 2 1/min gas mixture, composed of $1: 1$ air and oxygen, flow rate was used instead of pure air in Expt 10. All other conditions were the same as Expt 10. This experiment was designed to test the reaction of $P$. pastoris to oxygen concentration. The initial acetaldehyde concentration was $0.748 \%(5.834 \mathrm{~g} / \mathrm{L})$ which was about eight times of that in 
Expt 10. Maximum product concentration $1.7 \%(13.3 \mathrm{~g} / \mathrm{L})$ was obtained after 5 hours and then began to decrease quickly. This result was amazing. On the one hand, it seemed that excess dissolved oxygen concentration could enhance the production rate of acetaldehyde, on the other hand; it also increased the acetaldehyde inhibition rate on cells.

\section{Experiment 12}

This time, the mixture was composed of $1.51 / \mathrm{min}$ air and $0.51 / \mathrm{min}$ oxygen. The acetaldehyde concentration in the first hour was $0.087 \%(0.68 \mathrm{~g} / \mathrm{L})$ which is $1 / 9$ of Expt 11 . The acetaldehyde concentration reached the maximum $0.48 \%$ $(3.8 \mathrm{~g} / \mathrm{L})$ in the $12 \mathrm{th}$ hour. It then stayed almost the same concentration until 142th hour. From Expts 10, 11, and 12, it is easy to see that the more dissolved oxygen concentration, the more acetaldehyde produced and the less enzyme half-life.

\section{Experiment 13}

The mixed flow rate in Expt 12 was doubled to see how the activity of enzyme would change and hope that the enzyme activity could last longer. Obviously, the result was similar to Expt 12 with a little worse. It also indicated that the oxygen impact is more determinate than acetaldehyde inhibition. 
All conditions in Expt 10 were repeated except that the cells used was from different batch to that of Expt 10. The results are similar, perhaps a little better.

\section{Experiment 15}

All conditions were the same as Expt 14 except that the substrate concentration was $5 \%$ instead of $10 \%$. The acetaldehyde concentration in the first hour reached $0.05 \%$ $(0.39 \mathrm{~g} / \mathrm{L})$ which is $4 / 7$ of Expt 14 . The initial ethanol consumption rate was $5.54 \mathrm{~g} / \mathrm{L} / \mathrm{h}, 3 / 5$ of that in Expt 14 . The concentration vs. time profile was similar both in Expts 14 and 15. However, it is easy to see that Expt 14 had a better performance than Expt 15, even though the enzyme activity in Expt 15 is more stable than that of Expt 14 .

\section{Experiment 16}

The substrate concentration was $15 \%$ in this experiment. As expected, the initial production rate $11.54 \mathrm{~g} / \mathrm{L}$ was a little higher than Expt 14 and 15, and the enzyme activity was decreased a little faster than the previous two experiments. From the plot of acetaldehyde concentration vs. time profiles of Expts 14,15 , and 16, it seemed that the substrate inhibition began to appear as the ethanol concentration was greater than $10 \%$. 
APPENDIX D

COMPUTER PROGRAM FOR UNIFAC METHOD 


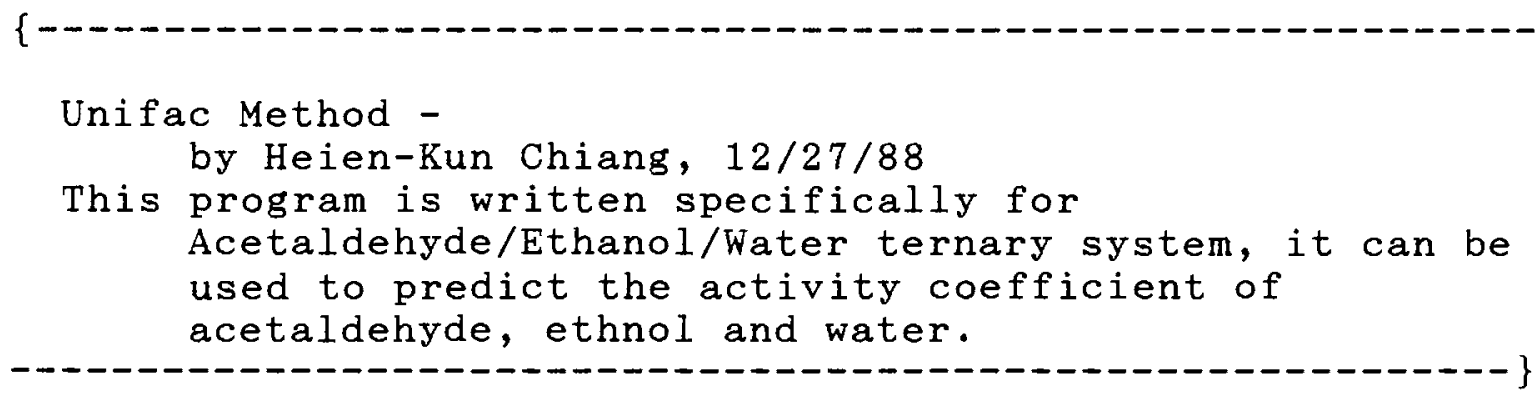

PROGRAM UNIFAC;

Uses

Crt, Dos, Graph; $\{$ Units in Turbo Pascal 5.0 \} Type

One_Dim = Array[1..3] of Real; Const

No_Comp $=3$;

ViewX1 $=70 ;$ ViewX2 $=570 ;$

ViewY1 $=25 ;$ ViewY2 $=325$; Var

Index, Step : Integer;

Temperature : Real ;

Comp_x, LnAct_x,

Act_x : One_Dim;

GraphDriver : Integer;

GraphMode : Integer;

MaxX, MaxY : Word;

ErrorCode : Integer;

MaxColor : Word;

$\mathrm{x}, \mathrm{y}$, No : Integer;

\{ No. of component $\}$

\{ Coordinate of $\}$

$\{$ Viewport $\}$ 


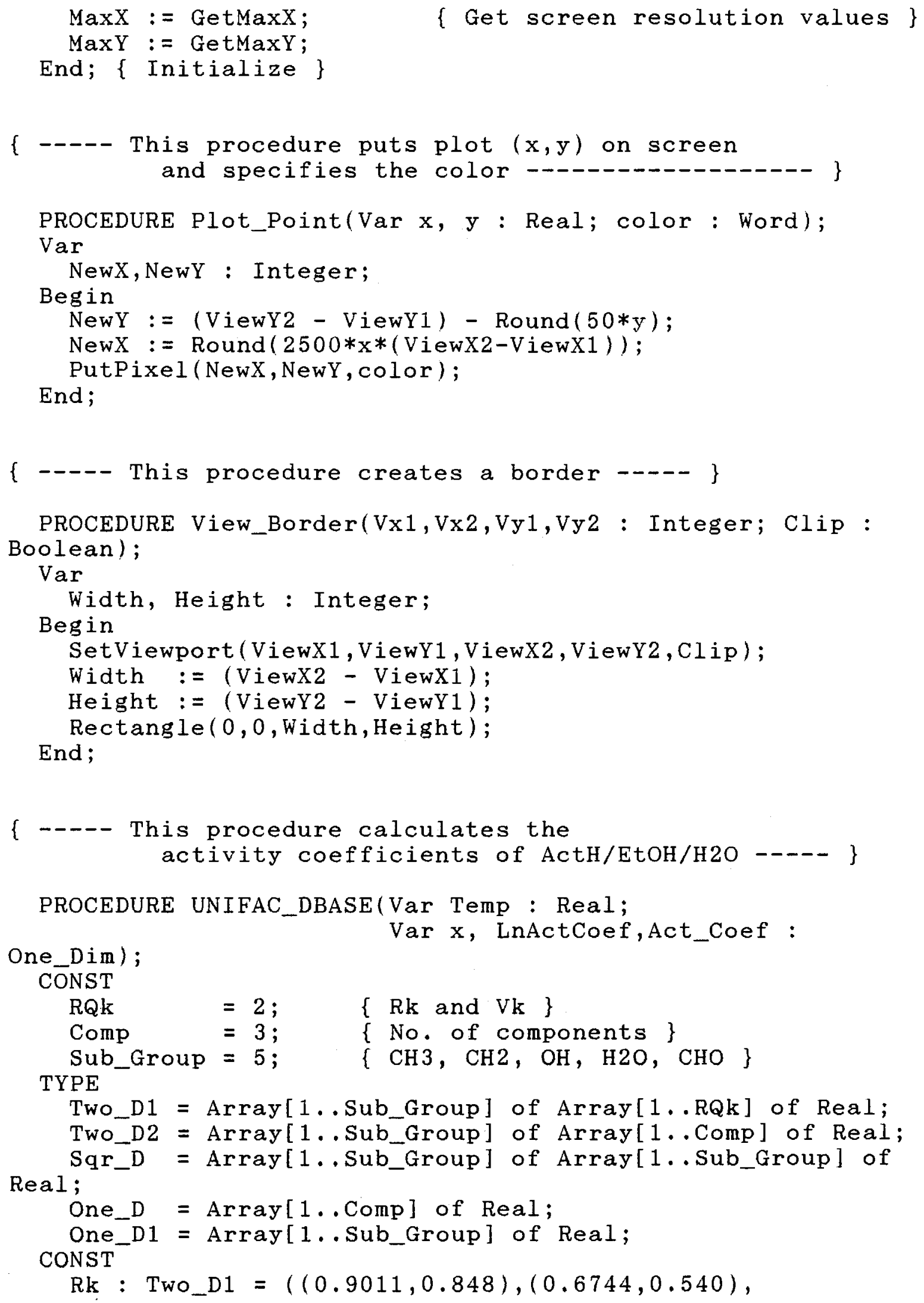




$$
\begin{aligned}
& (1.0000,1.2),(0.9200,1.400),(0.998,0.948)) \text {; } \\
& \mathrm{Vk}: \text { Two_D2 }=((1,1,0),(0,1,0),(0,1,0),(0,0,1),(1,0,0)) \text {; } \\
& \text { \{ ---- Interaction parameters ---- }\} \\
& \begin{aligned}
\text { a }: \text { Sqr } & = \\
((0,0,986.5,1318,677) & ,(0,0,986.5,1318,677) \\
& (156.4,156.4,0,353.5,441.8), \\
& (300,300,-329.1,0,-157.3) \\
& (505.7,505.7,-404.8,332.7,0)) ;
\end{aligned}
\end{aligned}
$$

VAR

Tau : Sqr_D;

G, Sk : Two_D2;

$\mathrm{r}, \mathrm{q}, \mathrm{Jx}, \mathrm{Lx} \quad$ : One_D;

Theta, Eta : One_D1;

$\mathrm{I}, \mathrm{J}, \mathrm{K}, \mathrm{M}$ : Integer;

J_Total, L_Total : Real;

$\mathrm{Mu}$, LnGammaC, LnGammaR : One_D;

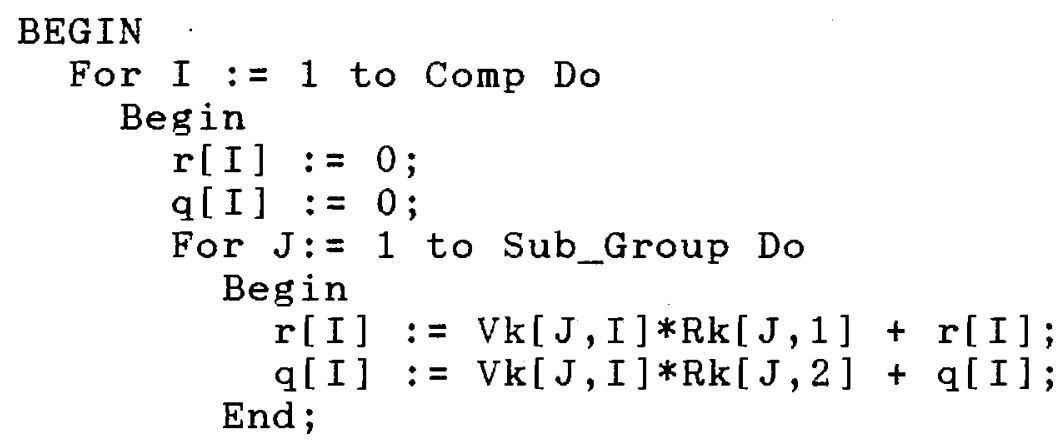




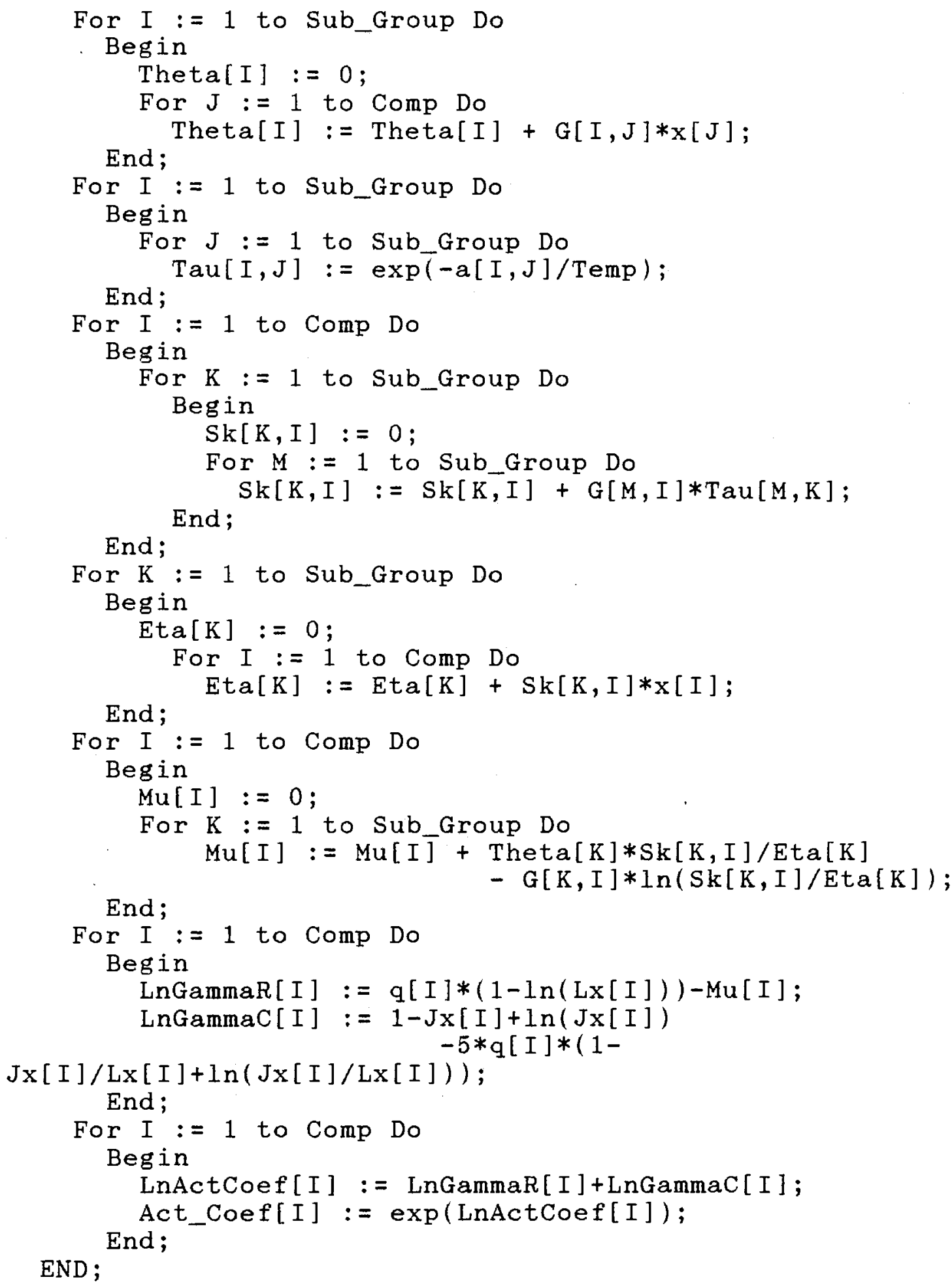




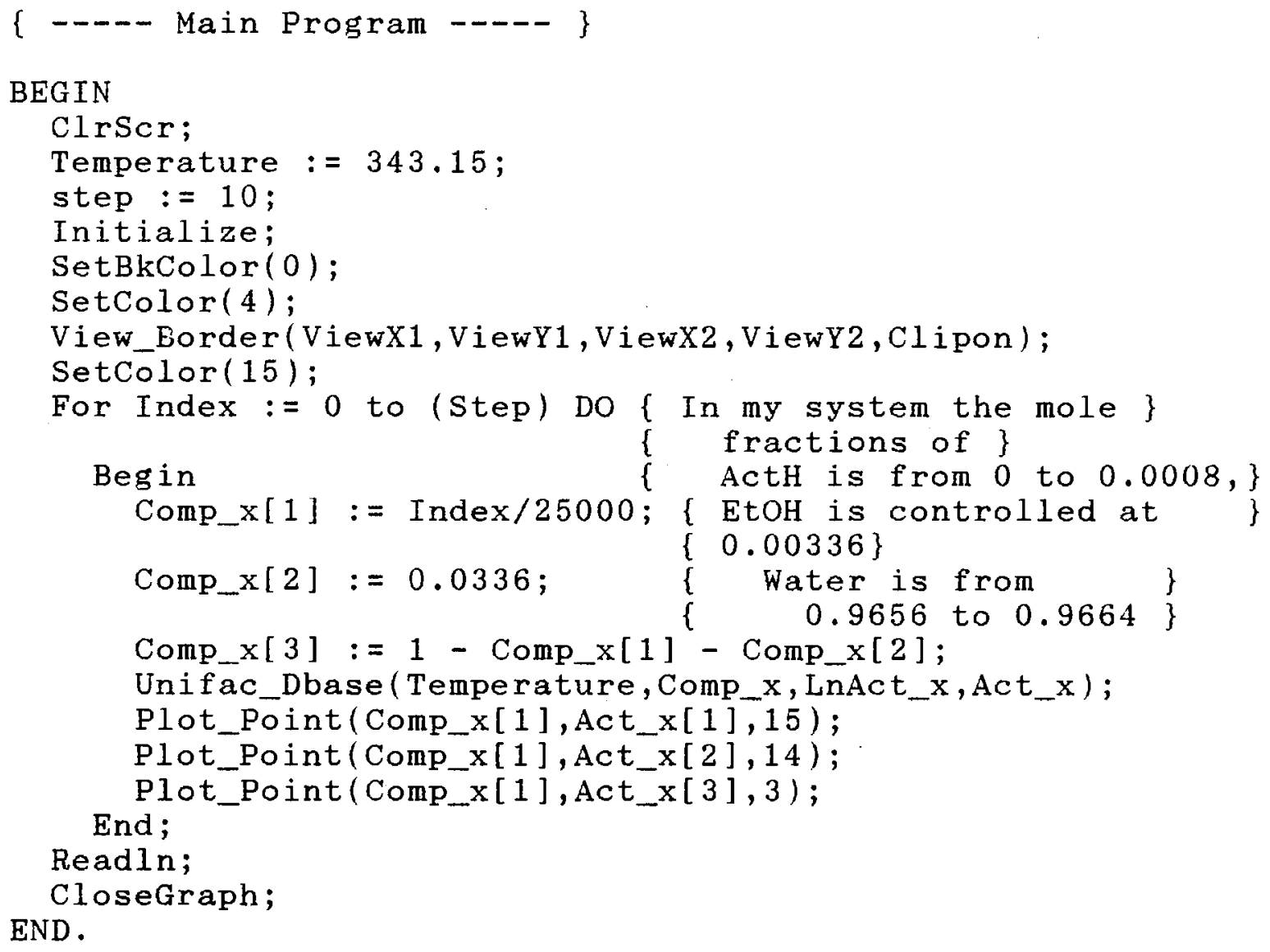


APPENDIX E

COMPUTER PROGRAM FOR PROPOSED KINETIC MODEL 


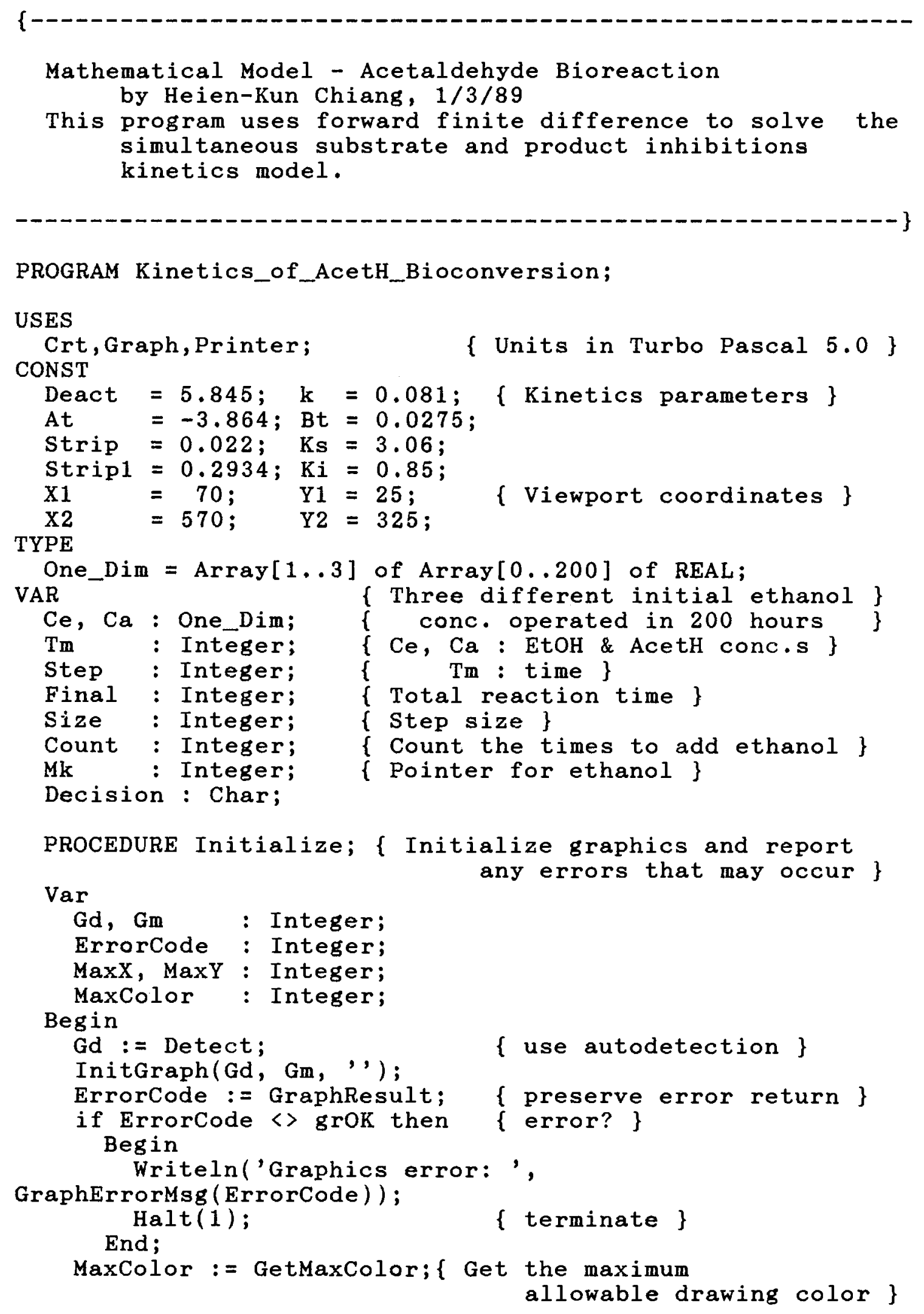

PROGRAM Kinetics_of_AcetH_Bioconversion;

USES

Crt,Graph,Printer; \{ Units in Turbo Pascal 5.0 \} CONST

Deact $=5.845 ; \quad k=0.081 ; \quad\{$ Kinetics parameters $\}$

At $\quad=-3.864 ; \mathrm{Bt}=0.0275$;

Strip $=0.022 ; \mathrm{Ks}=3.06$;

Strip1 $=0.2934 ; \mathrm{Ki}=0.85 ;$

$\mathrm{X} 1 \quad=70 ; \quad \mathrm{Y} 1=25 ; \quad\{$ Viewport coordinates $\}$

$\mathrm{X} 2 \quad=570 ; \quad \mathrm{Y} 2=325$;

TYPE

One_Dim = Array[1,.3] of Array[0..200] of REAL; VAR

$\mathrm{Ce}, \mathrm{Ca}$ : One_Dim;

Tm : Integer;

Step : Integer;

Final : Integer;

Size : Integer;

Count : Integer;

Mk : Integer;

Decision : Char;

PROCEDURE Initialize; \{ Initialize graphics and report

Var any errors that may occur \}

$$
\begin{array}{ll}
\text { Gd, Gm } & \text { Integer; } \\
\text { ErrorCode } & \text { Integer; } \\
\text { MaxX, MaxY : Integer; } & \text { Integer; }
\end{array}
$$




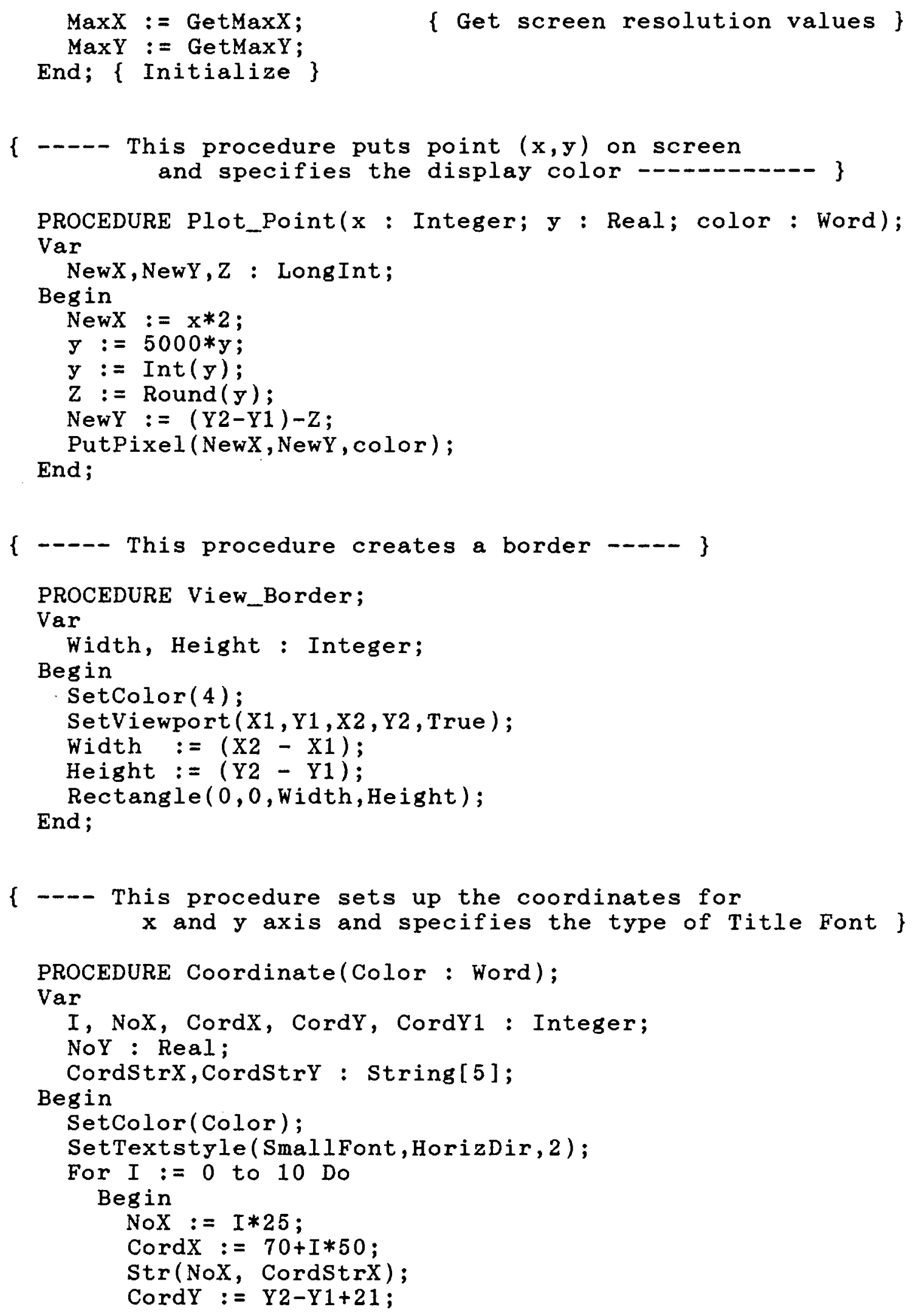




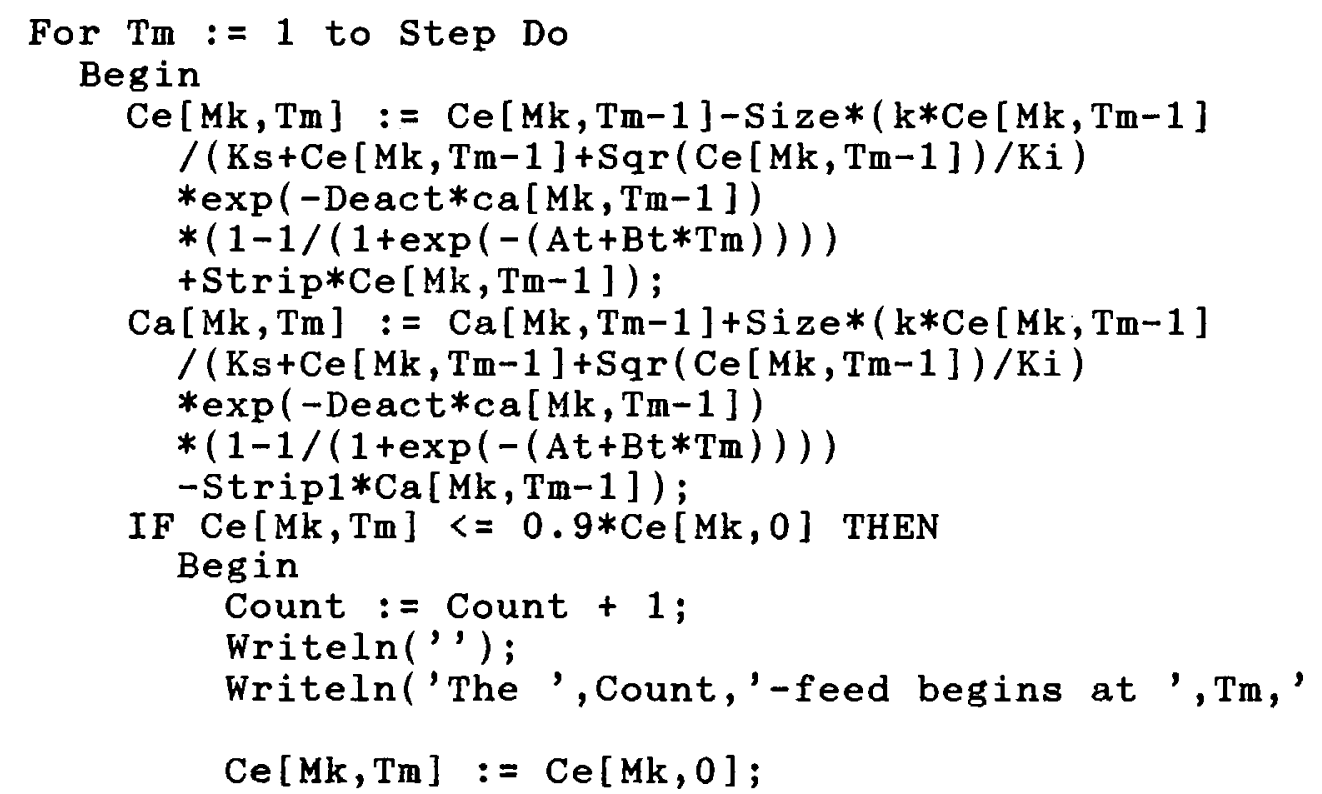
End;

Hour' ) ;

Writeln $(\mathrm{Tm}: 4, \mathrm{Ce}[\mathrm{Mk}, \mathrm{Tm}]: 20: 5, \mathrm{Ca}[\mathrm{Mk}, \mathrm{Tm}]: 20: 5)$;

End; End;

End;

') ;

Write('Do you want to see the graph: 〈Enter> " $\mathrm{Y}$ " or " $N$ "

Decision : = Readkey;

If (Decision $=$ ' $Y$ ') or (Decision $=$ ' $y$ ') Then

Initialize;

Coordinate (15);

SetColor (4);

View_Border;

For $M k:=1$ to 3 Do

Begin

For $\mathrm{Tm}:=0$ to 200 Do

Begin

\{ Plot_Point(Time, Ce[Mk,Time],14); \} End ;

Plot_Point ( Tm, Ca[Mk, Tm], Mk*3+4);

End;

Readln;

END.

CloseGraph; 


\section{APPENDIX F \\ TABULATED MATERIAL BALANCE FOR PROPOSED PROCESS}


TABLE 17

ETHANOL

(CASE 1)

AcetH Reactor Consumed Stripped Total Recycle* Feed $\mathrm{gal} / \mathrm{yr} \mathrm{Vol}$. (L) mol/bat mol/bat mol/bat mol/bat mol/bat

\begin{tabular}{rrrrrrr}
\hline 75000 & 189700 & 167817 & 580937 & 748754 & 348562 & 400192 \\
125000 & 316100 & 279695 & 968025 & 1247720 & 580815 & 666905 \\
200000 & 505800 & 447512 & 1548962 & 1996474 & 929377 & 1067097 \\
\hline
\end{tabular}

WATER

AcetH Reactor Produced Stripped Total Recycle* Feed $\mathrm{gal} / \mathrm{yr} \mathrm{Vol}$. (L) mol/bat mol/bat mol/bat mol/bat mol/bat

\begin{tabular}{rrrrrrrr}
\hline 75000 & 189700 & 167817 & 2937315 & 2769498 & 2349852 & 419646 \\
125000 & 316100 & 279695 & 4894492 & 4614797 & 3915594 & 699203 \\
200000 & 505800 & 447512 & 7831807 & 7384295 & 6265446 & 1118849 \\
\hline
\end{tabular}

* Recycle is assumed to be $60 \%$ of ethanol stripped out by air.

* Recycle is assumed to be $80 \%$ of water stripped out by air. 
TABLE 18

ETHANOL

(CASE 2)

AcetH Reactor Consumed Stripped Total Recycle* Feed gal/yr Vol.(L) mol/bat mol/bat mol/bat mol/bat mol/bat

\begin{tabular}{rrrrrrr}
\hline 75000 & 63300 & 55939 & 193850 & 249789 & 116310 & 133479 \\
125000 & 105400 & 93232 & 322777 & 416009 & 193666 & 222343 \\
200000 & 168600 & 149171 & 516321 & 665492 & 309792 & 355699 \\
\hline
\end{tabular}

* Recycle is assumed to be $60 \%$ of ethanol stripped out by air.

WATER

AcetH Reactor Produced Stripped Total Recycle* Feed gal/yr Vol.(L) mol/bat mol/bat mol/bat mol/bat mol/bat

\begin{tabular}{rrrrrrr}
\hline 75000 & 63300 & 55939 & 980137 & 924198 & 784110 & 140088 \\
125000 & 105400 & 93232 & 1632014 & 1538782 & 1305611 & 233171 \\
200000 & 168600 & 149171 & 2610602 & 2461431 & 2088482 & 372949 \\
\hline
\end{tabular}

* Recycle is assumed to be $60 \%$ of ethanol stripped out by air. 
TABLE 19

ETHANOL

(CASE 3)

\begin{tabular}{|c|c|c|c|c|c|c|c|}
\hline $\begin{array}{l}\text { Cel } \\
(\not{x})\end{array}$ & $\begin{array}{l}1 \mathrm{AcetH} \\
\mathrm{gal} / \mathrm{yr}\end{array}$ & $\begin{array}{l}\text { Reactor } \\
\text { Vol.(L) }\end{array}$ & $\begin{array}{c}\text { Consumed } \\
\mathrm{mol} / \mathrm{yr}\end{array}$ & $\underset{\text { mol }}{\text { Stripped }}$ & $\begin{array}{l}\text { dotal } \\
\text { mol/yr }\end{array}$ & $\begin{array}{c}\text { Recycle } \\
\mathrm{mol} / \mathrm{yr}\end{array}$ & $\begin{array}{c}\text { Feed } \\
\text { mol/yr }\end{array}$ \\
\hline 0.5 & 75000 & 252000 & $8.4 E+06$ & $4.6 \mathrm{E}+07$ & $5.5 E+07$ & $2.8 \mathrm{E}+07$ & $2.7 \mathrm{E}+07$ \\
\hline 0.5 & 125000 & 420000 & $1.4 \mathrm{E}+07$ & $7.7 \mathrm{E}+07$ & $9.1 \mathrm{E}+07$ & $4.6 \mathrm{E}+07$ & $4.5 E+07$ \\
\hline 0.5 & 200000 & 671200 & $2.2 E+07$ & $1.2 \mathrm{E}+08$ & 1. $5 \mathrm{E}+08$ & $7.4 \mathrm{E}+07$ & $7.2 E+07$ \\
\hline 1 & 75000 & 184000 & $8.4 E+06$ & $3.4 \mathrm{E}+07$ & $4.2 E+07$ & $2.0 \mathrm{E}+07$ & $2.2 E+07$ \\
\hline 1 & 125000 & 307000 & $1.4 \mathrm{E}+07$ & $5.6 E+07$ & $7.0 \mathrm{E}+07$ & $3.4 \mathrm{E}+07$ & $3.7 E+07$ \\
\hline 1 & 200000 & 491000 & $2.2 E+07$ & $9.0 \mathrm{E}+07$ & 1. $1 E+08$ & $5.4 E+07$ & $5.8 E+07$ \\
\hline 2 & 75000 & 154000 & $8.4 E+06$ & $2.8 E+07$ & $3.7 \mathrm{E}+07$ & $1.7 \mathrm{E}+07$ & $2.0 \mathrm{E}+07$ \\
\hline 2 & 125000 & 257000 & $1.4 \mathrm{E}+07$ & $4.7 \mathrm{E}+07$ & $6.1 E+07$ & $2.8 E+07$ & $3.3 E+07$ \\
\hline 2 & 200000 & 411000 & $2.2 E+07$ & $7.6 \mathrm{E}+07$ & $9.8 \mathrm{E}+07$ & $4.5 E+07$ & $5.3 E+07$ \\
\hline
\end{tabular}


TABLE 19 (Continued)

WATER

\begin{tabular}{|c|c|c|c|c|c|c|}
\hline $\begin{array}{l}\text { Cell AcetH } \\
(\%) \mathrm{gal} / \mathrm{yr}\end{array}$ & $\begin{array}{l}\text { Reactor } \\
\text { Vol. (L) }\end{array}$ & $\begin{array}{l}\text { Produced } \\
\text { mol/yr }\end{array}$ & $\begin{array}{l}\text { Stripped } \\
\text { mol/yr }\end{array}$ & $\underset{\mathrm{mol} / \mathrm{yr}}{\text { Total }}$ & $\begin{array}{r}\text { Recycle } \\
\mathrm{mol} / \mathrm{yr}\end{array}$ & $\begin{array}{c}\text { Feed } \\
\mathrm{mol} / \mathrm{yr}\end{array}$ \\
\hline $0.5 \quad 75000$ & 252000 & $8.4 \mathrm{E}+06$ & $2.3 E+08$ & $2.3 E+08$ & $1.9 \mathrm{E}+08$ & $3.8 \mathrm{E}+07$ \\
\hline 0.5125000 & 420000 & $1.4 \mathrm{E}+07$ & $3.9 E+08$ & $3.8 \mathrm{E}+08$ & $3.1 E+08$ & $6.4 \mathrm{E}+07$ \\
\hline 0.5200000 & 671200 & $2.2 \mathrm{E}+07$ & $6.2 E+08$ & $6.0 \mathrm{E}+08$ & $5.0 \mathrm{E}+08$ & $1.0 \mathrm{E}+08$ \\
\hline 175000 & 184000 & $8.4 E+06$ & $1.7 E+08$ & $1.6 \mathrm{E}+08$ & $1.4 \mathrm{E}+08$ & $2.6 E+07$ \\
\hline 1125000 & 307000 & $1.4 E+07$ & $2.9 E+08$ & $2.7 E+08$ & $2.3 E+08$ & $4.3 E+07$ \\
\hline 1200000 & 491000 & $2.2 E+07$ & $4.6 E+08$ & $4.3 E+08$ & $3.6 E+08$ & $6.9 \mathrm{E}+07$ \\
\hline 275000 & 154000 & $8.4 E+06$ & $1.4 E+08$ & $1.3 E+08$ & $1.1 E+08$ & $2.0 \mathrm{E}+07$ \\
\hline 2125000 & 257000 & $1.4 \mathrm{E}+07$ & $2.4 E+08$ & $2.2 E+08$ & $1.9 E+08$ & $3.4 \mathrm{E}+07$ \\
\hline 2200000 & 411000 & $2.2 \mathrm{E}+07$ & $3.8 \mathrm{E}+08$ & $3.6 \mathrm{E}+08$ & $3.1 E+08$ & $5.4 E+07$ \\
\hline
\end{tabular}




$$
\begin{gathered}
\operatorname{VITA}^{2} \\
\text { Heien-Kun Chiang } \\
\text { Candidate for the Degree of } \\
\text { Master of Science }
\end{gathered}
$$

Thesis: BIOLOGICAL PRODUCTION OF ACETALDEHYDE FROM ETHANOL USING NON-GROWING PICHIA PASTORIS WHOLE CELLS

Major Field: Chemical Engineering

Biographical:

Personal Data: Born in FengYuan, Taiwan, R.O.C., June 2, 1962, the son of Han-Weng and Chao Lin.

Education: Graduated from Taiwan Provincial Taichung First Boys' High School, Taichung, Taiwan, 1980; received Bachelor of Science Degree in Chemical Engineering from Tunghai University at Taichung in May, 1984; completed requirements for the Master of Science degree at Oklahoma State University in May, 1989 .

Professional Experience: Research Engineer of KUNNAN Enterprise, Tentzu, Taiwan, June, 1986, to July, 1987; Research Assistant, Department of Chemical Engineering, Oklahoma State University, December, 1987, to December 1988. 